\title{
Russian Federation: Detailed Assessment of Observance of IOSCO Objectives and Principles of Securities Regulation
}

This paper was completed in June 2011. The views expressed in this document are those of the staff team and do not necessarily reflect the views of the government of the Russian Federation or the Executive Board of the IMF.

The policy of publication of staff reports and other documents by the IMF allows for the deletion of market-sensitive information.

Copies of this report are available to the public from

International Monetary Fund $\bullet$ Publication Services

700 19th Street, N.W. • Washington, D.C. 20431

Telephone: (202) 623-7430 • Telefax: (202) 623-7201

E-mail: publications@imf.org • Internet: http://www.imf.org

\section{International Monetary Fund}

Washington, D.C. 
FinANCIAL SECtor ASSESSMENT Program StabiLity Module

RUSSIAN FEDERATION

IOSCO OBJECTIVES AND PRINCIPLES OF SECURITIES REGULATION

\section{DETAILED ASSESSMENT OF OBSERVANCE}

JUNE 2011

INTERNATIONAL MONETARY FUND

MONETARY AND CAPITAL MARKETS DEPARTMENT 


\section{Contents}

Glossary 3

I. Summary, Key Findings, and Recommendations 4

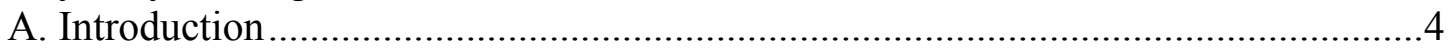

B. Institutional and Market Structure-Overview ..................................................6

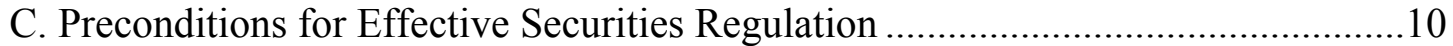

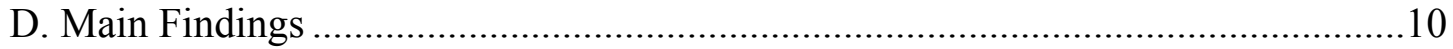

II. Recommended Action Plan and Authorities' Response ...............................................23

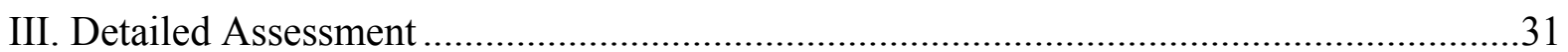

\section{Tables}

1. Summary Implementation of the IOSCO Principles - ROSCs ......................................13

2. Recommended Action Plan to Improve Implementation of the IOSCO Principles ............23

3. Detailed Assessment of Implementation of the IOSCO Principles ................................. 31 


\section{GLOSSARY}

$\begin{array}{ll}\text { AML/CFT } & \text { Anti-Money Laundering/Countering Terrorist Financing } \\ \text { AUM } & \text { Assets Under Management } \\ \text { BCPs } & \text { Basel Core Principles } \\ \text { BMMF } & \text { Bank Managed Mutual Funds also known as OFBU } \\ \text { CBR } & \text { Central Bank of Russia } \\ \text { CCP } & \text { Central Counterparty } \\ \text { CIS } & \text { Collective Investment Scheme } \\ \text { DCC } & \text { Depository Clearing Company } \\ \text { Duma } & \text { State Duma (Parliament) of the Russian Federation } \\ \text { FATF } & \text { Financial Action Task Force } \\ \text { FFMU } & \text { Federal Financial Monitoring Unit or Financial Intelligence Unit } \\ \text { FSAP } & \text { Financial Sector Assessment Program } \\ \text { FSFM } & \text { Federal Service for Financial Markets } \\ \text { FSIS } & \text { Federal Service for Insurance Supervision } \\ \text { IASB } & \text { International Accounting Standards Board } \\ \text { IFRS } & \text { International Financial Reporting Standards } \\ \text { IOSCO } & \text { International Organization of Securities Commissions } \\ \text { MICEX } & \text { Moscow Interbank Currency Exchange } \\ & \text { Multi-lateral Memorandum of Understanding on Consultation and } \\ \text { MMoU } & \text { Cooperation and Exchange of Information } \\ \text { MoF } & \text { Ministry of Finance } \\ \text { MoU } & \text { Memorandum of Understanding } \\ \text { NAUFOR } & \text { National Association of Securities Markets Participants } \\ \text { NFA } & \text { National Securities Markets Association (dealers) } \\ \text { NCC } & \text { National Clearing Center } \\ \text { NSD } & \text { National Settlement Depository } \\ \text { OJSC } & \text { Open Joint Stock Companies } \\ \text { PARTAD } & \text { Professional Association of Registrars, Transfer Agents, and Depositories } \\ \text { RID } & \text { Russian Institute of Directors } \\ \text { ROSC } & \text { Report on Observance of Standards and Codes } \\ \text { RTS } & \text { Russian Trading System } \\ \text { SRO } & \text { Self-Regulatory Organization } \\ \text { UNIDROIT } & \text { International Institute for the Unification of Private Law } \\ \text { US\$ } & \text { US Dollars } \\ \text { USFC } & \text { FinPotrebSoyuz Union of Financial Services Consumers, an Inter-regional } \\ & \text { Non-Governmental Organization } \\ & \end{array}$




\section{SUMMARY, KEY FINDINGS, AND RECOMMENDATIONS}

\section{This assessment reviews the regulatory framework in place for the oversight of} the capital markets of the Russian Federation as of June 2011. The assessment concludes that, since the previous assessment, the regulatory authority for the capital markets, which is the Federal Service for Financial Markets (FSFM), has led the adoption of significant reforms in applicable legislation and undertaken ambitious normative (regulatory) initiatives directed to meeting the IOSCO benchmarks for which the process of implementation is ongoing. The assessment also finds that FSFM's ability to come into full compliance would be materially advanced by the adoption of pending legislation related to exchanges, prudential supervision, bank secrecy, and consolidated supervision. The FSFM absorbed the Federal Service on Insurance Supervision (FSIS) as of March 4, 2011. Subsequent changes added certain other non-banking financial institutions to FSFM's remit and will transfer certain of its normative powers with respect to capital requirements for market professionals and the diversification of mutual fund assets to the Ministry of Finance (MoF). Other changes also are expected to be made by Resolution of the Government of the Russian Federation that place more authority within the MoF that may affect the operational exercise by FSFM of those normative (regulatory) powers delegated by law to them that affect the capital markets (except auditor and banking activities that previously were committed to the $\mathrm{MoF}$ and the $\mathrm{CBR}$ respectively). In consequence, it is important in reading this assessment to understand that, first, it only assesses those aspects of FSFM's operations that relate to capital markets and is not addressing FSFM's responsibilities with respect to insurance or non-banking financial institutions more generally; and second, that this assessment is made as of a specific point in time. Therefore, this assessment does not, and cannot, assess how the new framework, the new alignment of powers and authorities under that framework, and the recently adopted changes and/or pending legislation is working or will work in practice. The findings relative to implementation in this assessment may be improved after a period of experience during which the FSFM operates using its new authorities subject to its new accountability arrangements. This assessment, then, evaluates the regulatory framework in place as of the "as of" date of the report, and the operational activities of FSFM as it was operated and structured prior to the absorption of its new functions.

\section{A. Introduction}

\section{This IOSCO assessment was conducted as part of a financial sector assessment} led by the IMF under Dimitri Demekas. The on-site portion was conducted between March 27 and April 13, 2011. Andrea M. Corcoran, an external consultant, with many years of regulatory experience acted as assessor. The assessment is based on information available as of June 2011. 


\section{Information and methodology used for assessment}

3. The assessment is based on the Objectives and Principles of Securities Regulation of 1998 (IOSCO Principles) and the related Assessment Methodology adopted in 2003 and reissued in 2008. It does not assess the nine new IOSCO Principles adopted in June 2010 for which no formal assessment guidance has yet been issued. The detailed portion does however contain some comments on the potential impact of these pending changes. The preceding full assessment published in 2003, was based on field work conducted in 2002. That assessment was not performed in accordance with the IOSCO Assessment Methodology.

\section{This assessment benefitted from a 2008 update of the detailed IOSCO} Assessment of 2003, and current comments thereon, submitted by FSFM in lieu of a self-assessment using the Assessment Methodology. FSFM also provided answers to the questions and statistics on market structure contained in the general financial stability module questionnaire of the IMF. The assessor's contacts with the FSFM were materially assisted by a representative from FSFM's Department of International Affairs who acted as liaison and a consultant who has worked on bringing the Russian regulatory system for financial markets up to international standards. Meetings were held with the then head, Mr. Milovidov, relevant deputies, several senior operating staff, including representatives of the FSIS, and the aforesaid expert advisor. Additional meetings were held with officials from the two exchanges, Moscow Interbank Currency Exchange (MICEX) and the Russian Trading System Stock Exchange (RTS), the head of National Association of Securities Market Participants (NAUFOR), the self-regulatory organization (SRO) for brokerage firms, the Financial Services Consumer Union (a non-governmental association, headed by the head of the agency that preceded the FSFM), market participants, an international law firm doing business in Russia, the Institute of Public Directors (RID) and the American Chamber of Commerce. The mission leader also met with Mr. Pankin, the new head of the combined agency in an exit conference held in April.

\section{The assessor consulted the following laws:}

- "On the Securities Market, FZ-39 (Securities Law),"

- "On Protection of the Rights and Lawful Interests of Investors in the Securities Markets, FZ-46 (Investor Protection Law),"

- "On Countering the Illegal Use of Insider Information and Market Manipulation FZ224 (Insider Law),"

- "On Joint Stock Companies FZ-208 (Company Law),"

- "On Investment Funds, FZ-156 (CIS Law),"

- "Code of Administrative Offenses, FZ-9 (Admin. Code),"

- "Law on Banks and Banking Activities, (Banking Law)," 
- $\quad$ the "Insolvency Law, FZ-127, including relevant amendments concerning receivership and administration of financial institutions in FZ-65, dated Arpril 22, 2010)," and

- " $\quad$ "On Clearing and Clearing Activity, FZ-8 (Clearing Law)."

Also considered were Presidential Decrees No. 314 (March 9, 2004), and 207

(March 4, 2011), Resolution of the Government of the Russian Federation, No. 317

(June 30, 2004), as well as numerous pieces of pending legislation and the regulations referred to herein.

6. The laws, regulations and decrees reviewed were issued in Russian. In that there has been a plethora of recent legislation and rulemaking in various stages of adoption, it is difficult for the assessor to confirm that the description of the law is in every case totally current. For example the English reporting service indicated on versions of the law provided by the service that there might be subsequent amendments that were not yet reflected. In some cases, there were official translations, others were translated during the mission by IMF translators or the FSFM, some were available on the web in English, some were translated using Google's facility, or verbally during the course of the mission. The assessment was rendered more difficult by the fact that the English version of the FSFM website was unavailable during the mission. Though portions of the former site could be found through the Internet, the links to laws were not operational. Many meetings were conducted with the assistance of excellent interpreters.

\section{B. Institutional and Market Structure_-Overview}

\section{FSFM is the sole regulator of: solo securities market professionals (brokers,} dealers, portfolio managers, and other intermediaries); issuers; collective investments (CIS), CIS management companies and special custodians; exchanges and market infrastructure, such as clearing and settlement arrangements, depositories, and registrars, for securities corporate bonds, and other products, including futures. However, the entity within the MICEX Group market complex, which trades foreign currency, is overseen by the Central Bank of Russia (CBR) as is the government bond market. FSFM has certain company law responsibilities, in particular with respect to tender offers, mergers and other combinations. FSFM oversees the public issuance of securities and registers all corporate bonds and equity offers, except for certain short term debt, described as commercial paper. Many securities transactions, however, are conducted within banking structures as opposed to through separate securities broker subsidiaries. FSFM is the regulator for certain of the securities functions performed within banks, such as special custodial functions, brokerage, or asset management. However, FSFM is not the regulator of pooled investment funds offered by banks to their customers (bank managed mutual funds or BMMFs), though it may authorize the management companies. The assets under management in BMMFs are declining and overall, such bank funds are relatively small, about US\$230,000,000 in 2011. The FSFM regulates the contents of disclosures by public companies and nonbank financial 
institutions engaged in capital markets transactions (professional market participants). The Ministry of Finance (MoF) is responsible for establishing accounting and auditing standards. As of March 4, 2011, FSFM assumed the functions related to insurance supervision. The alignment of responsibilities, leadership of the combined agency, and initial proposals for the distribution of powers and authorities were announced in April. These announcements would give additional authority to the Ministry of Finance with respect to the issuance of regulations related to prudential matters, such as capital, but preserved the assignment of supervisory and operational functions in that area to the FSFM.

\section{FSFM has full licensing authority with respect to the professional market} participants subject to its jurisdiction, and can grant, condition, suspend, revoke, or deny licenses, without approval by any other authority within the government. FSFM has administrative powers, including the power to issue secondary legislation or normative decrees, as specifically spelled out in primary legislation, the power to provide interpretations and guidance, and the power to impose monetary sanctions and to compel information from any person. FSFM has substantial authority under all of the laws referenced above and other laws that have been adopted and/or are pending such as the draft law, known as "On Amendments to the Securities Law and to Certain Legislative Acts of the Russian Federation (Prudential Supervision Law).

9. The securities market has grown and become more sophisticated over the years. As did other markets, there was a decline in volume and value in 2008 , with recovery in $2009 .{ }^{1}$

RTS INDEX DYNAMICS, 1995-2009

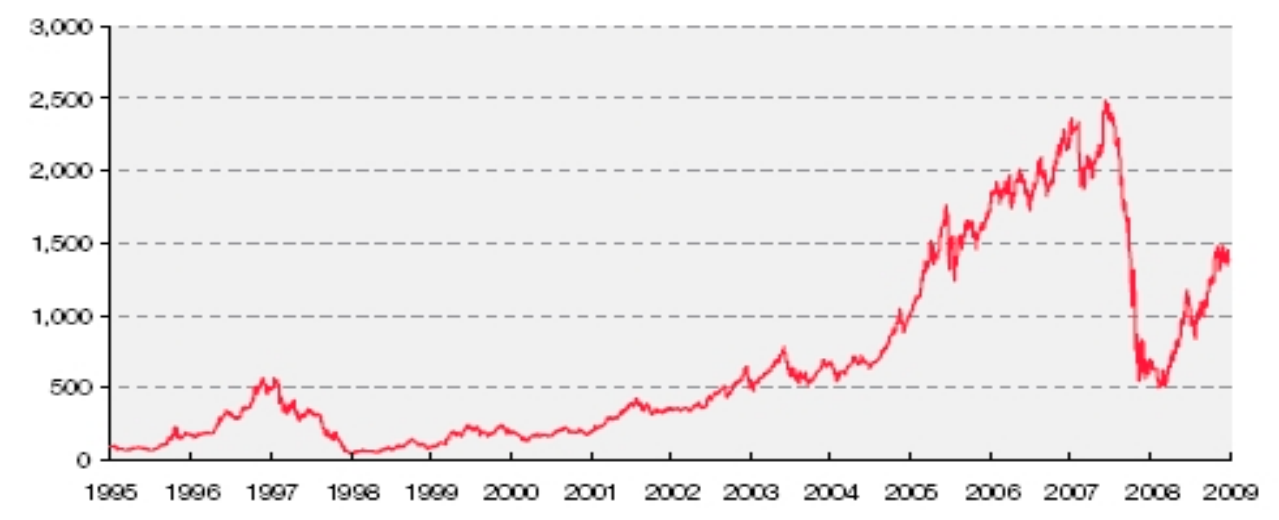

\footnotetext{
${ }^{1}$ Source: RTS. The graph represents the most active index, which is a dollar based index, representing 85 percent of market capitalization. Source: MICEX. The graph represents the MICEX 10 index to the date of this report.
} 


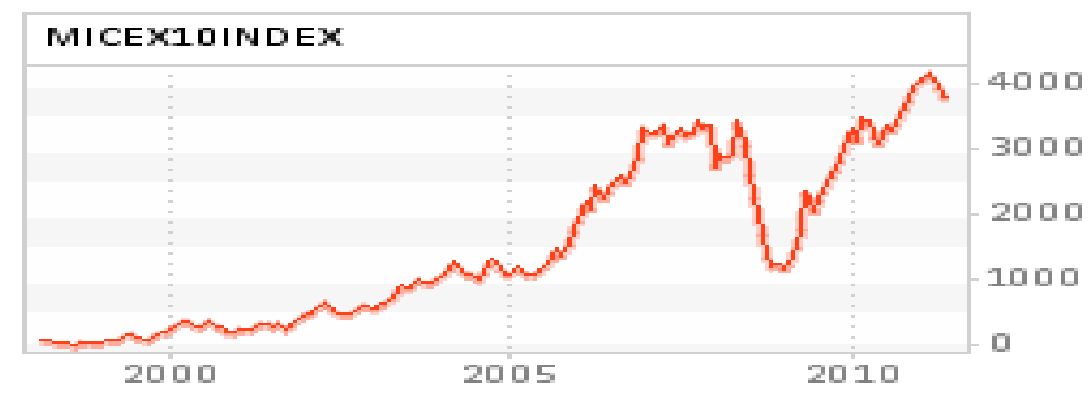

10. Although the numbers are volatile, Russia's equity markets are about mid-size among world markets. As of 2009, OECD reports indicate that Russia's market capitalization as a percentage of GDP was at an approximate par with several developed countries, such as France, the Netherlands, and Japan, and above that of Germany. The numbers, however, appear to change radically, year on year, and market uncertainty, from global events, elections or other matters, can lead to dramatic changes. There is also some significant cross border foreign direct investment; for example, Pepsi Cola recently bought Wimm-Bill-Dann, Russia's largest dairy and beverages company, and Lebedyansky, Russia's largest juice maker.

11. The number of market participants continues to grow. Nonetheless, fewer than 1 percent of the economically active population have individual brokerage accounts and less than 2 percent of GDP is invested in pension and other long term investment vehicles. Private pension funds (non-state funds), which are regulated by FSFM declined in number from 290 in 2005 to 150 in 2010 (although the figures on assets under management in such funds are not available.) The collective investment industry is predominantly made up of unit investment trusts. Reports for 2010 disclose about US\$41 billion AUM in 1461 funds distributed among three categories - open end, closed end and interval. The largest number of funds, constituting more than 33 percent of the dollar amount invested, are real estate funds; these are mostly captive closed end funds used to finance commercial property development, that are disappearing due to the recent withdrawal of a tax benefit. Although there has been an attempt to develop a longer term bond market, most activity is in the shorter range (one to two year durations) and during the height of the crisis some issuers experienced debt servicing issues. In 2010, in respect of the corporate bond market, there were 364 issuers and 663 issues, with a total value in circulation of US\$88.6 billion, approximately US\$81 billion was in circulation in government debt. There are 1800 authorized professional market participants (that is, brokers, dealers, asset managers, special custodians and depositories) distributed within the Russian Federation.

\section{The Russian securities markets in particular have been volatile in the last five} years, reflecting the inflow and outflow of money and the crisis. Foreign investment banks, for example, report that US\$20 billion of foreign investment exited the markets in the first quarter of 2011. This volatility is continuing, and is reflected in the changes in market capitalization in relation to GDP. A large percentage of the securities traded by volume and 
value are carried out by banks for their own account, as they use equities for collateral, owing to a lack of other alternatives such as long term bonds. The top ten market participants account for almost 50 percent of trading and, in consequence, what impacts banks as large participants directly affects the securities markets and vice versa. RTS, in contrast, noted during interviews that much of its volume, which includes direct access trading, is now retailoriented.

\section{While overall the markets are growing some have expressed concern that capital} formation is moving offshore citing recent planned listings in Hong Kong and London. For example, Valars Group, one of Russia's largest grain trading companies, was planning an IPO on the Warsaw Stock Exchange in May. Consolidation is also occurring, some of it prompted by purchase of private by government-controlled entities; for example Sberbank, owned 60.25 percent by the CBR, recently purchased 80 percent of Troika Dialog, the oldest and largest private investment bank in Russia. Alfa Bank, a non-government owned commercial bank wanted to acquire AKB Bank of Moscow, however VTB Bank, a government-owned bank ultimately prevailed. At the same time, on November 27, 2010, the Russian Government issued Resolution No. 2101-re-endorsing the Projected Plan/Program for Privatization of Federal Property and Guidelines for Privatization of Federal Property for 2011-2013 (the "Privatization Program"), under which multiple privatizations, including that of a portion of Sberbank are expected to occur. These "reprivatization" actions, coupled with other structural changes and modernizations of the regulatory system, potentially may provide renewed support to the securities markets if they provide fair pricing, and proper disclosure and shareholder protections.

\section{MICEX Group and RTS, the two main Russian exchanges executed a binding} merger agreement on June 29, 2011, following an expression of intent in March. The two entities expect to conclude their combination by year end. The total value of the combined deal is about US\$5 billion, with the majority ownership of 75 percent to be in the shareholders of MICEX. The new exchange will be 50 percent owned by state-controlled institutions, including CBR, Sberbank, VTB and Gazprom, though CBR indicated that it might reduce its stake prior to the deal's conclusion. The total market capitalization for all equities traded on both MICEX and RTS was about US\$1 trillion as of January 2011. MICEX is listed as among the top 20 exchanges per the World Federation of Exchanges. RTS's largest market is FORTS, or Futures and Options RTS, which settles through a central counterparty (CCP). The total number of futures and options contracts traded on FORTS in $2010^{2}$ were 623,992,623 as reported to the Futures Industry Association.

15. There are a large number of registered public companies, but only a tiny (less than one) percent are listed on the exchanges. Of these the 10 largest issues account for

\footnotetext{
${ }^{2}$ Value is usually not quoted for futures markets due to the fact that the nominal value can be misleading. Therefore, this is the number of contracts traded unadjusted for contract size.
} 
56.8 percent of market value and over 80 percent of market activity; the 30 largest account for 81.4 percent of market capitalization. Exchanges can admit companies to trading without listing, and also without authorization of the issuer. In 2010, according to FSFM statistics, there were 499 issuers admitted to trading on organized markets.

\section{Preconditions for Effective Securities Regulation}

\section{Securities exchanges and capital markets are contractual and rules-driven} ventures. Although some of the rules are embedded in exchange trading platforms, the integrity and equity of the application of the rules and of the conduct of public offerings are critical to maintaining market confidence. Similarly, in that securities are a legally created negotiable form of property interest, the integrity of how those interests are created, held and transferred is critical to their intrinsic value as is the governance structure of the issuers. Russia has invested huge efforts, over a lengthy period, to try to improve the legal and operational framework within which its markets operate. Nonetheless, there remains significant uncertainty about the integrity of the legal system that supports contracts and market rules and as to the expertise of the courts in financial matters. Currently a number of initiatives are underway that would help address these "rule of law"-related issues, including: improved accounting standards, provisions for finality of settlement, better rules of administration, initiatives that move toward the creation of a central depository, enhanced ownership and control reporting, provisions for an investor compensation fund, more intensive monitoring of market abuses and improved laws to address these, better means to enforce the proper conduct of business with retail market participants, and exploration of ways to enhance the availability and fairness of alternative dispute resolution regimes. Such improvements should be aggressively pursued.

\section{Main Findings}

\section{Overall as many improvements are brand new and many changes remain} pending, these findings reflect that many beneficial changes, which overtime may improve the performance of the regulator, are as of the date of this assessment, largely untested in practice.

(i) Principles 1-5, Principles relating to the Regulator: Improvements have been made in certain of the powers and authorities assigned to the regulator and certain regulatory as opposed to supervisory powers and authorities have been reassigned. At the present time, FSFM has the capacity to issue regulations in its remaining areas of competence, subject only to the condition of proper legal structure under the Federal Constitution, in consultation with other governmental entities as appropriate. Prior to the recent changes the FSFM operated substantially on a day-to-day basis, without political interference. Nonetheless, during the transitional period of uncertainty, there was a lack of transparency about ongoing legal initiatives that raised some concerns about whether the impending changes could adversely affect this existing level of regulatory independence. For example, the new alignment, as 
projected, will explicitly require MoF approval for certain matters. Although such consultation should not be a factor in day-to-day operations and supervision, the actual operational procedures have yet to be clarified.

(ii) Principles 6-7, Principles relating to self-regulation: Although the Russian SROs have the ability to make and enforce binding rules on their members, membership is voluntary and only a third of professional market participants belong. If the FSFM obtains the authority sought under the Prudential Supervision Law, currently in its second reading before the Duma, professional market participants that deal with the retail public will be required to belong to an SRO subject to FSFM oversight. FSFM will be able to use that SRO to improve the development and enforcement of conduct of business and customer fairness requirements and to institute more expeditious dispute resolution and mediation processes. Exchanges and other market operators are required to enforce their rules but are not regarded as selfregulatory organizations under Russian law.

(iii) Principles 8-10, Principles relating to enforcement of securities regulation. New rules to define the offenses of market abuse and insider trading, to require the maintenance of insider lists and to improve the ability to investigate violations against third parties as well as licensees are achievements as is the institution of new real-time trade monitoring capability within the FSFM. However, the sufficiency of these changes to detect and deter misconduct should be tested as they are implemented and cases are brought where warranted. Further, the ability to obtain general bank records for natural persons to conduct securities regulation and to investigate any securities law violation remains an issue. To the extent legal changes are needed to remedy this, they should be aggressively pursued.

(iv) Principles 11-13, Principles for cooperation in regulation: The powers to obtain information and to share it have been augmented since the prior report. Further improvements are pending in consolidated supervision/banking legislation which will remove certain remaining limitations, facilitating intergovernmental communication for financial market oversight. The FSFM should aggressively pursue becoming a full signatory to the IOSCO Multi-lateral Memorandum of Understanding Concerning Consultation and Cooperation and the Exchange of Information (MMoU). It should also seek to document its cooperative and investigative information sharing arrangements with the CBR and other relevant authorities and to keep relevant performance statistics. (See also Principles 24 and 29.)

(v) Principles 14-16, Principles for Issuers: New disclosure rules requiring material event reporting and ownership and control reporting, which attempt to improve information on indirect and connected ownership and to guide continuous disclosure have been adopted, as has the requirement for preparers and management to be liable for the accuracy of disclosure. Pending legislation would treat Directors as fiduciaries and a new Presidential Decree requires Ministers to step down from the supervisory boards of government-sponsored enterprises. These are sound improvements, which need some testing in practice. Regulatory 
vigilance in enforcing these requirements should determine whether the requirements are increasing sufficiently the transparency of ownership and related transactions.

(vi) Principles 17-20, Principles for collective investment schemes: The FSFM has legislation that recognizes that CIS are vehicles for retail investment. In this regard it provides a framework of substantial protections. It is now in the course of adding some modernizations, which include more flexibility for sophisticated investors and broader use of derivatives under EU-like requirements for diversification and leverage. FSFM should take steps to ensure that surveillance programs keep abreast of the growth of products and structures in this market. All marketing of mutual funds should be covered by securities requirements.

(vii) Principles 21-24, Principles for market intermediaries; new capital requirements are being phased in albeit planned increases for brokers due in July were cancelled. FSFM is also adding new measures to determine the operational capacity of intermediaries as part of the licensing qualification process and considering an early warning process. These initiatives should be pursued. The legislative ability to appoint an authorized representative from FSFM to operate a professional market participant for which the license has been suspended or withdrawn, or to operate a provisional administration, to manage and/or wind down a distressed firm and to require enhanced risk management and other prudential measures are pending. The FSFM should take into consideration its experience with intermediaries in using these new supervisory powers and should move to update its existing periodic inspections regime/algorithm by adding some risk-based analyses and random checks for records, capital and other compliance requirements. The operation of the new alignment of functions should be kept under review. Prompt steps also should be taken to put into place the authority to create an investor compensation fund and to develop appropriate contingency plans.

(viii) Principles 25-30, Principles for the Secondary Market. New technical capacity to undertake real time surveillance of trading was obtained last year. Experience with the alerts generated through this surveillance facility, and the reporting by exchanges of defined nonstandard transactions (potential market abuses), should enable the FSFM to better detect and deter market misconduct and to investigate/and or report suspicious transactions. Ongoing processes to revisit the listing, admission to trading and market structure should be continued to improve price reporting. As measures are adopted to provide the legal underpinning for a central counterparty and rationalization of the securities settlement system, the FSFM should ensure that its own regulatory methods and programs are adjusted so as to supervise the new operations in an effective, comprehensive way including back-testing of the extent to which margin/default coverage is achieved. Contingency and cooperative information sharing arrangements (or a crisis management plan, which addresses various types of crises) should be in place to address market disruption or failure of an intermediary. 


\section{Table 1. Summary Implementation of the IOSCO Principles-ROSCs}

If material changes result from the realignment of powers and authorities to accommodate the transfer of insurance functions and the change in leadership of the FSFM, or otherwise, the rating contained herein may require further assessment.

\begin{tabular}{|c|c|c|}
\hline Principle & Grading & Findings \\
\hline $\begin{array}{l}\text { Principle 1. The } \\
\text { responsibilities of the } \\
\text { regulator should be } \\
\text { clearly and objectively } \\
\text { stated }\end{array}$ & $\mathbf{P I}$ & $\begin{array}{l}\text { - The FSFM's powers and authorities, in so far as they pertain to } \\
\text { securities functions and professionals, are set out comprehensively in } \\
\text { the law, including relevant Presidential decrees and Resolutions of the } \\
\text { Government of the Russian Federation. In combination, these laws } \\
\text { grant the FSFM a number of normative authorities within its } \\
\text { competence, including as to the securities functions conducted by } \\
\text { banks. Not all marketing of bank-managed collective investments is } \\
\text { under the direct oversight of the FSFM, however. } \\
\text { - The accessibility of the applicable laws would be improved by } \\
\text { attempting to provide a consolidated text and by reinstating a publicly } \\
\text { available English translation. } \\
\text { - There is an informal working arrangement with the CBR for the } \\
\text { oversight of commonly supervised entities. This arrangement has not } \\
\text { been documented to address the sharing of information to combat } \\
\text { securities law violations. } \\
\text { - All supervisory functions over insurance were transferred to the } \\
\text { FSFM on March 4, } 2011 \text { as were such functions with respect to certain } \\
\text { other non-banking financial institutions as of June. The alignment of } \\
\text { functions between the FSFM and the MoF has not yet been finally } \\
\text { agreed. }\end{array}$ \\
\hline $\begin{array}{l}\text { Principle 2. The } \\
\text { regulator should be } \\
\text { operationally } \\
\text { independent and } \\
\text { accountable in the } \\
\text { exercise of its functions } \\
\text { and powers }\end{array}$ & PI & $\begin{array}{l}\text { - FSFM currently has the authority to grant, condition, suspend and } \\
\text { revoke licenses without interference. FSFM also has been granted } \\
\text { broad inspection and sanctioning powers with respect to capital markets } \\
\text { professionals and participants. These powers appear to be unaffected } \\
\text { by the recent changes in the overall structure, functions and } \\
\text { accountability of the FSFM. } \\
\text { - Under the new structure, the FSFM will retain powers to issue } \\
\text { secondary legislation (regulation or norms) in its areas of remaining } \\
\text { competence, subject in certain matters of importance to approval by the } \\
\text { MoF. With respect to capital requirements and the diversification } \\
\text { requirements for mutual funds, the MoF will have normative powers in } \\
\text { coordination with the FSFM. } \\
\text { - It is premature to evaluate how this rearrangement of functions and } \\
\text { authorities will operate in practice. The process for making these } \\
\text { changes was not transparent. } \\
\text { - The head of the agency is not appointed for a fixed term, there are } \\
\text { no criteria for removal, and the agency itself does not have legal } \\
\text { protection from liability for the performance of its mandates in good faith, } \\
\text { all matters of concern to IOSCO and other financial standards setters. }\end{array}$ \\
\hline $\begin{array}{l}\text { Principle } 3 . \text { The } \\
\text { regulator should have }\end{array}$ & $\mathbf{P I}$ & $\begin{array}{l}\text { - The FSFM has made a substantial effort since } 2008 \text { to obtain all } \\
\text { the powers and authorities necessary to be IOSCO-compliant. In this }\end{array}$ \\
\hline
\end{tabular}




\begin{tabular}{|c|c|c|}
\hline Principle & Grading & Findings \\
\hline $\begin{array}{l}\text { adequate powers, proper } \\
\text { resources and the } \\
\text { capacity to perform its } \\
\text { functions and exercise } \\
\text { its powers }\end{array}$ & & $\begin{array}{l}\text { respect, FSFM has undertaken an enormous project to obtain } \\
\text { expanded information sharing powers and to make clear its } \\
\text { administrative authority with respect to third parties. } \\
\text { - More authority is currently projected to be provided with respect to } \\
\text { access to (i) information regarding the general bank accounts of natural } \\
\text { persons and (ii) information necessary for overall prudential supervision } \\
\text { of groups, as the residual limitations on interagency sharing of bank } \\
\text { records for regulatory and supervisory purposes are currently expected } \\
\text { to be removed in pending legislation. } \\
\text { - FSFM's ability to obtain bank records apparently does not now } \\
\text { extend to natural persons or to enforcement of securities laws } \\
\text { generally. } \\
\text { - FSFM will need sufficient resources to implement the beneficial } \\
\text { new powers it has obtained and to enable it to attract sufficiently expert } \\
\text { personnel to oversee the evolving markets appropriately, a matter of } \\
\text { concern to the investing public. FSFM's existing budget may not be } \\
\text { sufficient to accommodate adequate training to assure that the } \\
\text { expertise of FSFM staff matches its expanded mandate. }\end{array}$ \\
\hline $\begin{array}{l}\text { Principle } 4 \text {. The } \\
\text { regulator should adopt } \\
\text { clear and consistent } \\
\text { regulatory processes }\end{array}$ & BI & $\begin{array}{l}\text { - The FSFM commits its general and specific actions to writing; all of } \\
\text { its actions are subject to appeal in the courts; and procedures affecting } \\
\text { the FSFM are documented both in a Federal Law, the Administrative } \\
\text { Code, and also in an internal general regulation. While there is a means } \\
\text { to be heard at least on the papers in individual proceedings in practice, } \\
\text { this process could be made more explicit. } \\
\text { - FSFM has oversight over the exchanges and organized markets, } \\
\text { but disciplinary actions of SROs and exchanges are appealable only to } \\
\text { the courts. } \\
\text { - New proposals are published on FSFM's website and there is an } \\
\text { opportunity for comment. The industry indicates that the opportunity for } \\
\text { increased dialogue is welcome. Feedback statements on the handling } \\
\text { of comments are not currently part of the consultation process. } \\
\text { Interpretations must be given in writing and within a specified time } \\
\text { frame. } \\
\text { - FSFM removed its English language website and it was not } \\
\text { operational during this assessment. A website that is accessible not } \\
\text { only in Russian, but also in a language more broadly understood in the } \\
\text { financial community, as previously was the case, is a factor in attracting } \\
\text { offshore business. } \\
\text { - The FSFM supports the use of alternative dispute resolution } \\
\text { mechanisms, but does not mandate that financial market professionals } \\
\text { w submit to this type of process on request of customers. } \\
\text { - Complaints may lead to investigations; more statistics or } \\
\text { performance metrics would make clearer how such matters are handled } \\
\text { and disposed of. }\end{array}$ \\
\hline $\begin{array}{l}\text { Principle } 5 \text {. The staff of } \\
\text { the regulator should } \\
\text { observe the highest } \\
\text { professional standards }\end{array}$ & BI & $\begin{array}{l}\text { - FSFM staff is subject to general and specific law on professional } \\
\text { conduct and confidentiality. They are not permitted to engage in } \\
\text { personal trading. They are also subject to the Insider Law, which makes } \\
\text { violations sanctionable. }\end{array}$ \\
\hline
\end{tabular}




\begin{tabular}{|c|c|c|}
\hline Principle & Grading & Findings \\
\hline & & $\begin{array}{l}\text { - FSFM has not consolidated the applicable requirements in a Code } \\
\text { of Conduct or as a part of the Internal Code that could be made publicly } \\
\text { available. It should also introduce monitoring processes. (See also } \\
\text { Principle 2). }\end{array}$ \\
\hline $\begin{array}{l}\text { Principle } 6 \text { The } \\
\text { regulatory regime should } \\
\text { make appropriate use of } \\
\text { self-regulatory } \\
\text { organizations (SROs) } \\
\text { that exercise some direct } \\
\text { oversight responsibility } \\
\text { for their respective areas } \\
\text { of competence and to } \\
\text { the extent appropriate to } \\
\text { the size and complexity } \\
\text { of the markets }\end{array}$ & $\begin{array}{c}\text { Not } \\
\text { Assessed }\end{array}$ & $\begin{array}{l}\text { - The Securities Law contemplates the use of SROs that are like } \\
\text { industry professional/trade associations. These have the ability to } \\
\text { comment on agency action, can make binding rules of conduct for their } \\
\text { members and offer dispute resolution services, pursuant to relevant } \\
\text { law. } \\
\text { - As membership in any such SRO is voluntary, their usefulness in } \\
\text { expanding the scope of the regulator's capacity to oversee the market } \\
\text { and to enforce protections to retail customers is limited. SROs do } \\
\text { provide a mechanism for informed consultation on agency actions. } \\
\text { - The Prudential Supervision Law that is pending a second reading in } \\
\text { the Duma will make participation in an SRO mandatory for financial } \\
\text { intermediaries that deal with retail customers and will create a } \\
\text { securities compensation fund through such SRO for retail investors. } \\
\text { - Planned initiatives to strengthen retail protections would be } \\
\text { welcome by market participants. Over time the scope of these } \\
\text { arrangements might be further evaluated, and extended to other types } \\
\text { of clients, such as institutional clients representing the interests of retail } \\
\text { clients like CIS. }\end{array}$ \\
\hline $\begin{array}{l}\text { Principle } 7 . \text { SROs } \\
\text { should be subject to the } \\
\text { oversight of the regulator } \\
\text { and should observe } \\
\text { standards of fairness } \\
\text { and confidentiality when } \\
\text { exercising powers and } \\
\text { delegated } \\
\text { responsibilities }\end{array}$ & BI & $\begin{array}{l}\text { - The FSFM has a program both to oversee SROs-it conducted four } \\
\text { reviews in 2010_and to cooperate with them on inspections and in } \\
\text { deterring and detecting market abuses and other misconduct. SROs, } \\
\text { however, are not subject to a legal obligation of confidentiality as is the } \\
\text { FSFM. Membership in SROs also is now voluntary (See Principle } 6 \\
\text { above). } \\
\text { - Securities exchanges, although they must enforce their rules as a } \\
\text { matter of contract and to satisfy FSFM requirements, and are obligated } \\
\text { to report specific types of non-standard transactions by their members } \\
\text { or subscribers to the FSFM, are not designated as SROs by the law } \\
\text { (See Principle 25). } \\
\text { - All SRO rules must be approved, and can be deemed effective in } \\
30 \text { days if there is no objection from FSFM. } \\
\text { - The FSFM indicates that it intends to provide additional oversight to } \\
\text { any SRO designed for protection of retail investors. }\end{array}$ \\
\hline $\begin{array}{l}\text { Principle } 8 \text {. The } \\
\text { regulator should have } \\
\text { comprehensive } \\
\text { inspection, investigation } \\
\text { and surveillance powers }\end{array}$ & PI & $\begin{array}{l}\text { - The FSFM has comprehensive inspection powers, including the } \\
\text { capacity to inspect brokers' files and to trace transactions to a broker's } \\
\text { bank accounts. } \\
\text { b There are plans either to further clarify or to amend relevant } \\
\text { banking law to remove limitations on access to general bank accounts } \\
\text { of natural persons for all regulatory purposes. Such accounts can } \\
\text { currently be reached with respect to entities for manipulation and } \\
\text { insider trading actions under the relevant securities laws, but as to } \\
\text { natural persons the banking law has not been amended. }\end{array}$ \\
\hline $\begin{array}{l}\text { Principle } 9 . \text { The } \\
\text { regulator should have }\end{array}$ & BI & $\begin{array}{l}\text { - FSFM has investigative and enforcement powers to bring } \\
\text { administrative actions against third parties as well as licensees. }\end{array}$ \\
\hline
\end{tabular}




\begin{tabular}{|c|c|c|}
\hline Principle & Grading & Findings \\
\hline $\begin{array}{l}\text { comprehensive } \\
\text { enforcement powers }\end{array}$ & & $\begin{array}{l}\text { - FSFM also has received brand new authority to combat market } \\
\text { abuses, such as insider trading and manipulation that define the } \\
\text { offenses with particularity. In fact, FSFM has already brought a case. } \\
\text { - The new provisional administrator powers create the possibility to } \\
\text { freeze assets and for FSFM personnel to act as an authorized } \\
\text { representative to operate/or oversee the operations of a professional } \\
\text { market participant that is revoked or suspended or otherwise put under } \\
\text { administration. } \\
\text { - The FSFM is continuing to pursue enhancement of its enforcement } \\
\text { and sanctioning authorities. }\end{array}$ \\
\hline $\begin{array}{l}\text { Principle } 10 . \text { The } \\
\text { regulatory system should } \\
\text { ensure an effective and } \\
\text { credible use of } \\
\text { inspection, investigation, } \\
\text { surveillance and } \\
\text { enforcement powers and } \\
\text { implementation of an } \\
\text { effective compliance } \\
\text { program. }\end{array}$ & PI & $\begin{array}{l}\text { - The FSFM conducts an active inspection and investigation } \\
\text { program. It has withdrawn and revoked licenses, and undertaken an } \\
\text { energetic program of initiatives together with the Government, to get } \\
\text { the powers to become IOSCO-compliant in the enforcement area. } \\
\text { - The FSFM has also recently obtained new surveillance tools and } \\
\text { dedicated staff to identify suspicious transactions that can be modeled } \\
\text { to implement its new authority to combat various market abuses. } \\
\text { - FSFM also makes all of its sanctions public on its website. } \\
\text { - Some period of observation of the use of these new enforcement } \\
\text { powers and tools is necessary to determine how effectively they work in } \\
\text { practice. } \\
\text { - FSFM would benefit from improved performance indicators for its } \\
\text { enforcement program. }\end{array}$ \\
\hline $\begin{array}{l}\text { Principle } 11 \text { The } \\
\text { regulator should have } \\
\text { the authority to share } \\
\text { both public and non- } \\
\text { public information with } \\
\text { domestic and foreign } \\
\text { counterparts }\end{array}$ & BI & $\begin{array}{l}\text { - FSFM has the ability to share public and non-public information in } \\
\text { its files or available to it through inspection of licensees with domestic } \\
\text { and foreign authorities, including information with respect to the bank } \\
\text { accounts of legal entities (and maintained for business) to the full extent } \\
\text { of its ability to obtain such information } \\
\text { - There are plans to amend the Banking Law and or otherwise to } \\
\text { clarify that FSFM has access to the general bank accounts of natural } \\
\text { persons for regulatory purposes. In the interim, the FSFM has full } \\
\text { authority to assist with respect to those bank records by going through } \\
\text { a court process }\end{array}$ \\
\hline $\begin{array}{l}\text { Principle 12. Regulators } \\
\text { should establish } \\
\text { information sharing } \\
\text { mechanisms that set out } \\
\text { when and how they will } \\
\text { share both public and } \\
\text { non-public information } \\
\text { with their domestic and } \\
\text { foreign counterparts }\end{array}$ & I & $\begin{array}{l}\text { - The FSFM cooperates with both domestic and international } \\
\text { authorities. } \\
\text { - Although FSFM is still negotiating a protocol with the CBR, it has } \\
\text { understandings with other domestic regulators and it has specific MoUs } \\
\text { with } 15 \text { foreign authorities and a side letter with a 16th. Additionally it } \\
\text { sits on several domestic and international committees where important } \\
\text { contacts and informal networks are formed and where information is } \\
\text { shared verbally as well as an internal task force of all financial } \\
\text { authorities. } \\
\text { - FSFM should continue to pursue information sharing } \\
\text { arrangements with all jurisdictions that trade Russian equities or deposit } \\
\text { receipts. }\end{array}$ \\
\hline $\begin{array}{l}\text { Principle } 13 . \text { The } \\
\text { regulatory system should } \\
\text { allow for assistance to }\end{array}$ & PI & $\begin{array}{l}\text { The FSFM has full power and authority to share information with } \\
\text { foreign authorities without dual criminality or an independent interest in } \\
\text { the action to the full extent of its powers to obtain and use information }\end{array}$ \\
\hline
\end{tabular}




\begin{tabular}{|c|c|c|}
\hline Principle & Grading & Findings \\
\hline $\begin{array}{l}\text { be provided to foreign } \\
\text { regulators who need to } \\
\text { make inquiries in the } \\
\text { discharge of their } \\
\text { functions and exercise of } \\
\text { their powers }\end{array}$ & & $\begin{array}{l}\text { itself, which powers have been expanded recently. FSFM may need to } \\
\text { commence an investigation or inspection to do so, but has that power. } \\
\text { - FSFM should commence a reasoned process to become a } \\
\text { signatory to Annex A of the IOSCO MMoU within the deadline. In this } \\
\text { regard, FSFM has received substantial additional powers since } 2008 \text {, } \\
\text { can seek to clarify those ambiguities within its power to clarify, and can } \\
\text { confirm through IOSCO's process what further legal clarifications, such } \\
\text { as, on bank records of natural persons, are expected. } \\
\text { - Appropriate clarifications would raise the level of FSFM } \\
\text { compliance. }\end{array}$ \\
\hline $\begin{array}{l}\text { Principle 14. There } \\
\text { should be full, timely and } \\
\text { accurate disclosure of } \\
\text { financial results and } \\
\text { other information that is } \\
\text { material to investors' } \\
\text { decisions }\end{array}$ & $\mathbf{P I}$ & $\begin{array}{l}\text { - FSFM requires prospectus, financial and non-financial disclosure } \\
\text { and reporting. It defines what information must be submitted, conducts } \\
\text { prospectus reviews, and the review of periodic and ad hoc statements } \\
\text { and filings. } \\
\text { - The prospectus and material event disclosure requirements for } \\
\text { public companies, defined as companies with more than } 500 \\
\text { participants are contained in the Securities Law. The Company Law } \\
\text { also has disclosure requirements for public issuers. In addition to } \\
\text { specific requirements, the Securities Law has a general provision for } \\
\text { those issues it covers that requires that all information material to price } \\
\text { be disclosed. } \\
\text { - FSFM conducts reviews of issuers and public companies, both in } \\
\text { the regions and at headquarters, mostly via review of filed disclosure } \\
\text { documents, and periodic financial reports, but in some cases via on-site } \\
\text { inspections. Preparers of statements are liable for the accuracy of } \\
\text { disclosures, and the FSFM has in fact suspended and required the } \\
\text { correction of filings. } \\
\text { - FSFM has received important new authorities to look at indirect } \\
\text { control of entities, and has added additional material event reporting to } \\
\text { its disclosure requirements. Some experience with the application of } \\
\text { these enhancements to determine their effectiveness is necessary } \\
\text { before FSFM could be found to be fully compliant. FSFM and the } \\
\text { industry report that the effects of these changes and other actions have } \\
\text { been to increase the overall transparency of public companies (See } \\
\text { also Principle 15). } \\
\text { Efforts also are being made to improve accounting standards. The } \\
\text { efficacy of disclosure ultimately depends on the application of } \\
\text { accounting and auditing, and ownership information reporting. While } \\
\text { these matters are actively being improved, more experience is needed } \\
\text { with their implementation for FSFM to move to a higher level of } \\
\text { compliance. (See also Principle } 16 \text { ) }\end{array}$ \\
\hline $\begin{array}{l}\text { Principle } 15 \text {. Holders of } \\
\text { securities in a company } \\
\text { should be treated in a } \\
\text { fair and equitable } \\
\text { manner }\end{array}$ & PI & $\begin{array}{l}\text { A Code of Conduct for corporate governance was adopted in } \\
\text { 2002. The RTS and the MICEX require compliance with this Code for } \\
\text { their top tier companies. } \\
\text { - The FSFM also oversees company law, including pricing, relative } \\
\text { to take over transactions. The law provides for the protection of minority } \\
\text { rights. } \\
\text { - More experience with the application of new ownership and control } \\
\text { reporting procedures is required, but such reporting, if enforceable and }\end{array}$ \\
\hline
\end{tabular}




\begin{tabular}{|c|c|c|}
\hline Principle & Grading & Findings \\
\hline & & $\begin{array}{l}\text { enforced, should materially improve the ability to provide the requisite } \\
\text { protections . } \\
\text { - Directors and officers are not required to disclose any interest in } \\
\text { shares, only interests that cross a } 5 \text { percent or greater threshold. } \\
\text { - Required annual "comply or explain" disclosure for public } \\
\text { companies as to Code of good governance would improve the } \\
\text { information provided to shareholders. }\end{array}$ \\
\hline $\begin{array}{l}\text { Principle 16. Accounting } \\
\text { and auditing standards } \\
\text { should be of a high and } \\
\text { internationally } \\
\text { acceptable quality }\end{array}$ & PI & $\begin{array}{l}\text { - IFRS for consolidated financial reports of issuers and financial } \\
\text { markets participants is required after } 2015 \text {. } \\
\text { - While financial reports must still be filed in accordance with } \\
\text { Russian Accounting standards, IFRS-compliant statements also must } \\
\text { be disclosed now if IFRS is used for foreign offers or even for internal } \\
\text { reporting. The top tier of listed companies also uses IFRS pursuant to } \\
\text { exchange rules. } \\
\text { - Accounting and auditing oversight procedures should continue to } \\
\text { be strengthened. Additionally, as the requirement for IFRS is phased in, } \\
\text { adequate oversight and training of accountants and the regulators will } \\
\text { be important and will .need to be intensified. }\end{array}$ \\
\hline $\begin{array}{l}\text { Principle } 17 . \text { The } \\
\text { regulatory system should } \\
\text { set standards for the } \\
\text { eligibility and the } \\
\text { regulation of those who } \\
\text { wish to market or } \\
\text { operate a collective } \\
\text { investment scheme }\end{array}$ & PI & $\begin{array}{l}\text { - The FSFM has initial and ongoing licensing standards that involve } \\
\text { fit and proper criteria, including competence, lack of disqualifying } \\
\text { conduct, adoption of appropriate structures and controls and review. } \\
\text { - FSFM also has rules to prevent or require disclosure of related } \\
\text { party transactions, subject to certain exceptions comparable t those in } \\
\text { other jurisdictions. } \\
\text { - Firms that market funds must be licensed, except that banks can } \\
\text { place bank customers in bank-managed funds, without a brokerage } \\
\text { license. } \\
\text { - There are some gaps among the customer protections, such as } \\
\text { those related to best execution, although additional customer protection } \\
\text { rules could be provided by the relevant SRO for the management } \\
\text { company or possibly, otherwise, through the expected ability to } \\
\text { mandate the use of an SRO for intermediaries doing retail related } \\
\text { business. }\end{array}$ \\
\hline $\begin{array}{l}\text { Principle 18. The } \\
\text { regulatory system should } \\
\text { provide for rules } \\
\text { governing the legal form } \\
\text { and structure of } \\
\text { collective investment } \\
\text { schemes and the } \\
\text { segregation and } \\
\text { protection of client } \\
\text { assets }\end{array}$ & BI & $\begin{array}{l}\text { - FSFM has structural requirements for collective investment } \\
\text { schemes (CIS), whether joint stock companies (of which there are only } \\
\text { eight), or unit investment trusts, which treat their participants' interests } \\
\text { as securities. } \\
\text { - The law and related rules require the assets of the CIS to be } \\
\text { maintained at a non-affiliated "specialized" custodian. The custodian is } \\
\text { to maintain a register of unit holders, account for the transfer and } \\
\text { investment of subscriptions, and monitor investments and activities of } \\
\text { the management company relative thereto for compliance generally } \\
\text { with the law. } \\
\text { - The Investment Fund law recognizes that the portfolio assets of } \\
\text { the CIS are not part of the investment management company's estate, } \\
\text { nor are they amenable to the claims of debtors of individual fund } \\
\text { participants or of the special custodian. Similarly in the case of fund } \\
\text { companies, portfolio and other assets held for investors are available }\end{array}$ \\
\hline
\end{tabular}




\begin{tabular}{|c|c|c|}
\hline Principle & Grading & Findings \\
\hline & & $\begin{array}{l}\text { only to satisfy such investors' claims. } \\
\text { - A special administration procedure also is provided by that law in } \\
\text { the event of the need to wind down a fund or otherwise. } \\
\text { - There is a process whereby auditors confirm that fund money and } \\
\text { property are properly maintained, that custodial procedures are } \\
\text { observed, and that portfolio structures and net asset value } \\
\text { computations are correct. } \\
\text { - Acquisition of funds by other funds should be monitored to prevent } \\
\text { abuses. }\end{array}$ \\
\hline $\begin{array}{l}\text { Principle 19. Regulation } \\
\text { should require } \\
\text { disclosure, as set forth } \\
\text { under the principles for } \\
\text { issuers, which is } \\
\text { necessary to evaluate } \\
\text { the suitability of a } \\
\text { collective investment } \\
\text { scheme for a particular } \\
\text { investor and the value of } \\
\text { the investor's interest in } \\
\text { the scheme }\end{array}$ & I & $\begin{array}{l}\text { - Investment by laws and agreements, information on fund } \\
\text { composition, price reporting and financial reports for managers and } \\
\text { custodians, as well as specific and general qualitative disclosure is } \\
\text { required for investment funds. Among other things these relate to the } \\
\text { fund governance and management and their qualifications, investment } \\
\text { policies, fees and costs, and to the fact that performance gains cannot } \\
\text { be guaranteed. A particularly important disclosure is with respect to the } \\
\text { volatility of markets where liquidity is not assured. } \\
\text { - Risk warnings to retail investors should help to ensure they } \\
\text { understand the difference between investment funds and bank } \\
\text { accounts and/or bank offered funds to the extent that the protections } \\
\text { are not identical. } \\
\text { - The Investment Fund law provides specific requirements for SROs } \\
\text { to which management companies are now voluntary members. These } \\
\text { require such SROs to handle complaints, monitor for compliance with } \\
\text { applicable rules, cooperate with the FSFM, and bring disciplinary } \\
\text { procedures. } \\
\text { - See Principle } 4,6,7 \text { and } 23 \text { with respect to efforts to require } \\
\text { mandatory use of an SRO to provide more oversight of retail offerings } \\
\text { and education of customers. }\end{array}$ \\
\hline $\begin{array}{l}\text { Principle 20. Regulation } \\
\text { should ensure that there } \\
\text { is a proper and disclosed } \\
\text { basis for assets } \\
\text { valuation and the pricing } \\
\text { and the redemption of } \\
\text { units in a collective } \\
\text { investment scheme }\end{array}$ & BI & $\begin{array}{l}\text { - FSFM has specific requirements for the valuation of assets. There } \\
\text { are special provisions that apply to illiquid assets to promote the use of } \\
\text { fair/accurate valuations. Attentive oversight of the pricing of illiquid } \\
\text { assets, and of any related evaluators, is necessary. Clear provisions for } \\
\text { errors are needed, for example. } \\
\text { - NAV for open-ended funds has to be published daily on the } \\
\text { Internet site of the CIS management company and if funds are listed on } \\
\text { a stock exchange, the price must also be published through on-line data } \\
\text { feeds of authorized vendors. } \\
\text { - Closed end funds and interval funds must report on redemption } \\
\text { dates (which must be at least once yearly) and in the case of movable } \\
\text { assets not less frequently than quarterly. } \\
\text { (See Principle } 18 \text { for the role of auditors) }\end{array}$ \\
\hline $\begin{array}{l}\text { Principle 21. Regulation } \\
\text { should provide for } \\
\text { minimum entry } \\
\text { standards for market } \\
\text { intermediaries }\end{array}$ & BI & $\begin{array}{l}\text { - FSFM has fit and proper licensing requirements that include } \\
\text { statutory disqualifications and capital and educational qualifications and } \\
\text { professional competence requirements that apply to all intermediaries, } \\
\text { including (except for capital) banks undertaking securities functions. } \\
\text { - While currently licenses are issued on the documents, coupled } \\
\text { with a review of a certification as to no criminal record from the Ministry }\end{array}$ \\
\hline
\end{tabular}




\begin{tabular}{|c|c|c|}
\hline Principle & Grading & Findings \\
\hline & & $\begin{array}{l}\text { of Interior, there is a pending project to add a due diligence review of } \\
\text { operational capacity to conduct the business for which a professional } \\
\text { market participant is licensed. } \\
\text { - See Principle } 22 \text {. As capital requirements become more complex, } \\
\text { it will be important to have appropriately expert staff to conduct these } \\
\text { reviews. }\end{array}$ \\
\hline $\begin{array}{l}\text { Principle 22. There } \\
\text { should be initial and } \\
\text { ongoing capital and } \\
\text { other prudential } \\
\text { requirements for market } \\
\text { intermediaries that } \\
\text { reflect the risks that the } \\
\text { intermediaries undertake }\end{array}$ & PI & $\begin{array}{l}\text { - Minimum financial requirements for brokers were materially } \\
\text { increased to Rub } 35 \text { million (US } \$ 1.25 \text { million) in } 2010 \text {, and were to have } \\
\text { been further increased in July, } 2011 \text {. Special custodians and non- } \\
\text { settlement related depositories' capital will be increased to Rub } 80 \\
\text { million. as previously planned in July. } \\
\text { - More specific risk-based measures and ratios related to credit and } \\
\text { other risks are proposed to be added by the Prudential Supervision } \\
\text { Law, which is in its second reading. } \\
\text { - The development of specific requirements has now been } \\
\text { reassigned to the MoF and planned increases due for brokers in July } \\
\text { were postponed in May pending the projected adoption of the } \\
\text { Prudential Supervision Law. } \\
\text { - } \quad \text { Existing requirements will be augmented by the ability to undertake } \\
\text { appropriate due diligence, a new consolidated financial reports filing } \\
\text { requirement when it is applied, by the Consolidated Supervision } \\
\text { Banking Law, if and when adopted, and by the full implementation of } \\
\text { IFRS by } 2015 \text {. } \\
\text { - FSFM has no early warning requirements or procedures. } \\
\text { - These changes will require adequate expertise to supervise and } \\
\text { implement, including new inspection regimes and procedures, which } \\
\text { might reasonably focus on identifying and prioritizing risks as well as } \\
\text { random inspections to ensure that books and records are current and } \\
\text { that the capital rules are being followed properly. }\end{array}$ \\
\hline $\begin{array}{l}\text { Principle 23. Market } \\
\text { intermediaries should be } \\
\text { required to comply with } \\
\text { standards for internal } \\
\text { organization and } \\
\text { operational conduct that } \\
\text { aim to protect the } \\
\text { interests of clients, } \\
\text { ensure proper } \\
\text { management of risk, and } \\
\text { under which } \\
\text { management of the } \\
\text { intermediary accepts } \\
\text { primary responsibility for } \\
\text { these matters }\end{array}$ & PI & $\begin{array}{l}\text { - The Securities Law and FSFM regulations contain broad duties of } \\
\text { good faith, loyalty and fairness to customers. Recent regulations } \\
\text { adopted in } 2010 \text { permit through new monitoring procedures the ability to } \\
\text { better oversee customer first and other customer protection } \\
\text { requirements in real time and the new Insider Law makes market } \\
\text { operator personnel and professional market participants insiders with } \\
\text { respect to information received from their clients. } \\
\text { - The adoption, application and enforcement of business conduct } \\
\text { standards and other customer protections could be improved with the } \\
\text { use of a mandated SRO for intermediaries handling retail business. } \\
\text { - Currently the order handling requirements are not very specific, so } \\
\text { enforcement and oversight may be complicated----a general issue with } \\
\text { using principles, as opposed to rules, of supervision. These issues } \\
\text { could be ameliorated through use of an SRO that establishes best } \\
\text { practices providing more content to the principles. }\end{array}$ \\
\hline $\begin{array}{l}\text { Principle 24. There } \\
\text { should be a procedure } \\
\text { for dealing with the } \\
\text { failure of a market } \\
\text { intermediary in order to }\end{array}$ & PI & $\begin{array}{l}\text { - There are new powers to deal with firm financial distress, including } \\
\text { appointment of a temporary/provisional administrator, and, there are } \\
\text { additional new rules pending final legislative approval. } \\
\text { - } \quad \text { FSFM and the exchanges and the other relevant authorities need }\end{array}$ \\
\hline
\end{tabular}




\begin{tabular}{|c|c|c|}
\hline Principle & Grading & Findings \\
\hline $\begin{array}{l}\text { minimize damage and } \\
\text { loss to investors and to } \\
\text { contain systemic risk }\end{array}$ & & $\begin{array}{l}\text { contingency arrangements to deal with market and firm disruption, } \\
\text { making full use of their administration and information sharing powers, } \\
\text { which address several potential scenarios. See Principles } 1 \text { and } 29 . \\
\text { Such arrangements would need to evolve with the market and be kept } \\
\text { under continuous review. } \\
\text { - New authority to create an investor compensation scheme is } \\
\text { expected to come on line with pending legislation. }\end{array}$ \\
\hline $\begin{array}{l}\text { Principle 25. The } \\
\text { establishment of trading } \\
\text { systems including } \\
\text { securities exchanges } \\
\text { should be subject to } \\
\text { regulatory authorization } \\
\text { and oversight }\end{array}$ & BI & $\begin{array}{l}\text { - The FSFM has a licensing procedure for regulated exchanges and } \\
\text { organized markets, which includes fitness and financial requirements. } \\
\text { - A new law known as the Law on Exchanges and Organized } \\
\text { Trading is in the process of being adopted which may contain additional } \\
\text { improvements. } \\
\text { - Disclosure relative to the differential requirements as to each of the } \\
\text { specific tiers of trading is important to customer protection and fairness. }\end{array}$ \\
\hline $\begin{array}{l}\text { Principle 26. There } \\
\text { should be ongoing } \\
\text { regulatory supervision of } \\
\text { exchanges and trading } \\
\text { systems, which should } \\
\text { aim to ensure that the } \\
\text { integrity of trading is } \\
\text { maintained through fair } \\
\text { and equitable rules that } \\
\text { strike an appropriate } \\
\text { balance between the } \\
\text { demands of different } \\
\text { market participants }\end{array}$ & BI & $\begin{array}{l}\text { - The FSFM conducts oversight reviews of exchanges. In this regard } \\
\text { it visited the RTS in } 2010 \text {. Inspections result in a report, an exit } \\
\text { conference, and follow up. } \\
\text { - FSFM also works with the exchange personnel on emerging } \\
\text { issues. } \\
\text { - The FSFM now has additional authority to do its own monitoring of } \\
\text { suspicious transactions and potential violations and new technology to } \\
\text { apply these. Additionally regulations adopted in } 2010 \text { require all } \\
\text { organized markets and exchanges to submit various types of } \\
\text { information about non-standard and potentially abusive transactions to } \\
\text { the FSFM in a specified format. } \\
\text { - The FSFM would benefit from more metrics for evaluating } \\
\text { performance by exchanges of their compliance functions. }\end{array}$ \\
\hline $\begin{array}{l}\text { Principle 27. Regulation } \\
\text { should promote } \\
\text { transparency of trading }\end{array}$ & PI & $\begin{array}{l}\text { - Price and volume is reported by the market to the FSFM. The data } \\
\text { feeds are licensed in real time to commercial providers and they are } \\
\text { also available with a } 15 \text { minute time lag to the general public on line. } \\
\text { - Reporting of OTC transactions has been improved, consistently } \\
\text { with changes in the process being made globally, which are currently } \\
\text { being refined after the crisis. Almost all OTC reports are made through } \\
\text { RTS. } \\
\text { - How to address the prices of the same product listed or admitted to } \\
\text { trading at two exchanges in the same time zone continues to be subject } \\
\text { to regulatory scrutiny. } \\
\text { - The exchanges and the FSFM would benefit from staying abreast } \\
\text { of developments more generally about market structure, transparency } \\
\text { and related protections. }\end{array}$ \\
\hline $\begin{array}{l}\text { Principle 28. Regulation } \\
\text { should be designed to } \\
\text { detect and deter } \\
\text { manipulation and other } \\
\text { unfair trading practices }\end{array}$ & PI & $\begin{array}{l}\text { - Adoption of the law on market abuses, such as insider trading and } \\
\text { manipulation is a step forward and includes the sanction of } \\
\text { disgorgement of wrongful profits. } \\
\text { - The systems to deter and detect such misconduct are in the } \\
\text { process of being developed and tested as the law is being phased in. } \\
\text { The FFSM has a new real time surveillance tool, and the exchanges are } \\
\text { required also to enforce their rules against misconduct. Specific } \\
\text { exception reports on non-standard transactions are required by the }\end{array}$ \\
\hline
\end{tabular}




\begin{tabular}{|c|c|c|}
\hline Principle & Grading & Findings \\
\hline & & $\begin{array}{l}\text { exchanges to the FSFM to be made in a common format. (See also } \\
\text { Principles } 7 \text { and } 26 \text { ). } \\
\text { - Some experience is necessary to see how these improved } \\
\text { requirements work in practice and whether the penalties are dissuasive } \\
\text { and proportionate. }\end{array}$ \\
\hline $\begin{array}{l}\text { Principle 29. Regulation } \\
\text { should aim to ensure the } \\
\text { proper management of } \\
\text { large exposures, default } \\
\text { risk and market } \\
\text { disruption }\end{array}$ & PI & $\begin{array}{l}\text { - The exchanges have some rules with respect to these risks built } \\
\text { into their systems. The procedures for defaults are public. } \\
\text { - The FSFM has power to demand additional information from direct } \\
\text { market participants on clients within omnibus accounts. } \\
\text { - This power is untested. } \\
\text { - The FSFM should develop approaches that enable it to determine } \\
\text { where risks are originating in the market, and to follow up with other } \\
\text { regulators in conducting appropriate surveillance. } \\
\text { - Contingency procedures are not currently documented nor are } \\
\text { related cooperative arrangements with other regulators. There should } \\
\text { be documented contingency plans to address both general market and } \\
\text { firm disruptions (see also Principle } 24 \text { Key Q1). }\end{array}$ \\
\hline $\begin{array}{l}\text { Principle } 30 \text {. Systems } \\
\text { for clearing and } \\
\text { settlement of securities } \\
\text { transactions should be } \\
\text { subject to regulatory } \\
\text { oversight, and designed } \\
\text { to ensure that they are } \\
\text { fair, effective and } \\
\text { efficient and that they } \\
\text { reduce systemic risk }\end{array}$ & $\begin{array}{c}\text { Not } \\
\text { Assessed }\end{array}$ & $\begin{array}{l}\text { - Adoption of the Clearing Law that provides a legal underpinning for } \\
\text { final settlement in a central counterparty system and for close out } \\
\text { netting and related risk management parameters is an important step } \\
\text { forward. } \\
\text { - It is important to assure that as implemented the risk management } \\
\text { and oversight of the CCP system is sufficient to meet international } \\
\text { requirements. } \\
\text { - Such a system should bring more transparency to exposures, and } \\
\text { further facilitate anonymous trading. As it concentrates risk at the CCP, } \\
\text { however, the financial resources and margining and variation systems } \\
\text { are critical and appropriate and ongoing back testing of the sufficiency } \\
\text { of the risk management systems is important. } \\
\text { - The system still permits the use of multiple registrars or transfer } \\
\text { agents though issues relative to liability for custodianship obligations } \\
\text { have been clarified and the number of such agents is declining. Use of } \\
\text { a Central Security Depository which complies with the CPSS/IOSCO } \\
\text { standards for securities settlement systems, and US law for US mutual } \\
\text { funds investing offshore would send an important signal to the market } \\
\text { as to the integrity of the system for transfer of securities. }\end{array}$ \\
\hline
\end{tabular}




\section{Recommended ACtion Plan ANd AUthorities' Response}

\section{Recommended action plan}

\section{Table 2. Recommended Action Plan to Improve Implementation of the IOSCO Principles}

While legislative powers and authorities are now in place and more are pending, more experience is needed with how these new powers work in practice before IOSCO expectations can be said to be fully implemented.

\begin{tabular}{|c|c|}
\hline Reference Principle & Recommended Action \\
\hline $\begin{array}{l}\text { 1.The responsibilities of the } \\
\text { regulator should be clear and } \\
\text { objectively states. }\end{array}$ & $\begin{array}{l}\text { - The CBR and the FSFM should document a protocol for } \\
\text { cooperation with respect to the oversight of entities or groups in } \\
\text { which they have a common interest. } \\
\text { - A consolidated version of law and regulations with linkages } \\
\text { should be on the website, ideally in English as the language of } \\
\text { finance, as well as in Russian. } \\
\text { - The distribution of powers in the new authority should be } \\
\text { promptly clarified and made readily accessible together with an } \\
\text { explanation of how the arrangements are expected to operate in } \\
\text { practice. }\end{array}$ \\
\hline $\begin{array}{l}\text { 2. The regulator should be } \\
\text { operationally independent and } \\
\text { accountable in the exercise of } \\
\text { its functions and powers. }\end{array}$ & $\begin{array}{l}\text { The new structure of the FSFM should be kept under } \\
\text { observation to ensure that the new alignment of functions does not } \\
\text { lead to day-to-day operational interference by the MoF } \\
\text { - Even if it is accepted protocol to resign upon a change of } \\
\text { political administration, under existing standards, the executive } \\
\text { director of a regulatory agency should be appointed for a fixed } \\
\text { term and the criteria for removal should be specified. } \\
\text { - Legal protection for good faith performance of the regulatory } \\
\text { mandate by FSFM should continue to be pursued. }\end{array}$ \\
\hline $\begin{array}{l}\text { 3. The regulator should have } \\
\text { adequate powers and } \\
\text { resources. }\end{array}$ & $\begin{array}{l}\text { - The skills, technical competences, IT facilities and human } \\
\text { and monetary resources of FSFM should keep pace with the } \\
\text { complexity and scope of its regulatory mission. } \\
\text { - The FSFM should determine if it needs additional types of } \\
\text { resources and a different skill mix than it has currently for its } \\
\text { resources to be equal to market demands; it should do a needs } \\
\text { assessment, prepare an action plan, and use it in constructing the } \\
\text { next rolling budget or amending this one. In particular FSFM } \\
\text { should retain the ability to hire external experts and should be } \\
\text { exempt from the government-wide headcount reduction. } \\
\text { - FSFM resources must be sufficeint to enable it to attract } \\
\text { sufficiently expert personnel to oversee the evolving markets } \\
\text { appropriately, a matter of concern to the investing public. The } \\
\text { budget should also accommodate training to assure that the } \\
\text { expertise of FSFM staff is sufficient to implement more complex } \\
\text { and nuanced requirements, to conduct due diligence, and to } \\
\text { implement new powers and authorities. }\end{array}$ \\
\hline
\end{tabular}




\begin{tabular}{|c|c|}
\hline Reference Principle & Recommended Action \\
\hline & $\begin{array}{l}\text { - FSFMs ability to obtain bank records should extend to } \\
\text { enforcement of securities laws generally and proper oversight of } \\
\text { regulated entities. The law should be amended if necessary to } \\
\text { provide FSFM sufficient powers to meet the requirements for } \\
\text { joining the IOSCO MMoU as a full signatory (see also Principles } 8 \\
\text { and 13) }\end{array}$ \\
\hline $\begin{array}{l}\text { 4. The regulator should adopt } \\
\text { clear and consistent regulatory } \\
\text { processes. }\end{array}$ & $\begin{array}{l}\text { - FSFM should maintain logs of complaint dispositions, } \\
\text { inspections, investigations and cases, and use them to determine } \\
\text { whether penalties are proportionate, consistent and dissuasive. } \\
\text { - The practice and procedure for an opportunity to be heard in } \\
\text { administrative proceedings should be documented giving content } \\
\text { to the Investor Protection Law. } \\
\text { - The regulator should continue to assure that to the extent } \\
\text { possible its processes are transparent, restore its English website, } \\
\text { consider the publication of feedback statements after consultation, } \\
\text { and support measures to provide expanded access to mediation } \\
\text { and alternate dispute forums. }\end{array}$ \\
\hline $\begin{array}{l}\text { 5. The staff of the regulator } \\
\text { should make appropriate use } \\
\text { of SROs that exercise some } \\
\text { director oversight responsibility } \\
\text { for their respective areas of } \\
\text { competence and to the extent } \\
\text { appropriate to their size. }\end{array}$ & $\begin{array}{l}\text { - FSFM should consider having a Code of Conduct for } \\
\text { employees specific to the agency and establishing monitoring } \\
\text { processes to ensure compliance. -Publication of professional } \\
\text { procedures and the internal regulation at the FSFM can help } \\
\text { promote confidence in the regulatory process (see also Principle } 2 \\
\text { on liability). }\end{array}$ \\
\hline $\begin{array}{l}\text { 6. The regulatory regime } \\
\text { should make appropriate use } \\
\text { of SROs that exercise some } \\
\text { direct oversight responsibility } \\
\text { for their respective areas of } \\
\text { competence and to the extent } \\
\text { appropriate to their size. }\end{array}$ & $\begin{array}{l}\text { - The FSFM should continue to actively use what Russian lau } \\
\text { deems as SROs to provide some oversight of professional } \\
\text { qualifications and business conduct standards and serve as a type } \\
\text { of conduit or trade association for obtaining comment from more } \\
\text { than one perspective on the costs and benefits of rule proposals } \\
\text { and other matters. } \\
\text { - The FSFM should explore how best to use of its pending } \\
\text { authority with respect to a mandatory SRO for market } \\
\text { professionals serving retail customers (i) to provide additional } \\
\text { resources for customer protection, (ii) to ensure a high level of } \\
\text { consistency in the rules relative to retail customer protection, and } \\
\text { (iii) to develop a sufficient capital base for a risk-adjusted } \\
\text { compensation fund. } \\
\text { - FSFM should promptly implement any such authority once } \\
\text { obtained. }\end{array}$ \\
\hline $\begin{array}{l}\text { 7. SROs should be subject to } \\
\text { the oversight of the regulator } \\
\text { and should observe standards } \\
\text { of fairness and confidentiality } \\
\text { when exercising powers and } \\
\text { delegated responsibilities. }\end{array}$ & $\begin{array}{l}\text { SROs have access to sensitive information as the result of } \\
\text { their inspection activities. It may be that the information is } \\
\text { protected in their hands from improper use by internal rules or } \\
\text { membership agreements. } \\
\text { - FSFM should adopt an explicit requirement that an SRO } \\
\text { must treat non-public information in accordance with professional } \\
\text { standards of confidentiality equivalent to those required of FSFM, } \\
\text { or of any other authority whose information the SRO may be using } \\
\text { if higher. }\end{array}$ \\
\hline
\end{tabular}




\begin{tabular}{|c|c|}
\hline Reference Principle & Recommended Action \\
\hline $\begin{array}{l}\text { 8. The regulator should have } \\
\text { comprehensive inspection, } \\
\text { investigation and enforcement } \\
\text { powers. }\end{array}$ & $\begin{array}{l}\text { - The FSFM should seek a declaration or legislative } \\
\text { amendment confirming its ability to directly access general bank } \\
\text { records for all regulatory purposes. } \\
\text { - FSFM might consider exploring whether at headquarters, } \\
\text { using a methodology that identifies key risks, coupled with random } \\
\text { reviews of the currency of records would increase the efficiency } \\
\text { and effectiveness of the inspection process (see also Principle 22). }\end{array}$ \\
\hline $\begin{array}{l}\text { 9. The regulator should have } \\
\text { comprehensive enforcement } \\
\text { powers. }\end{array}$ & $\begin{array}{l}\text { - The FSFM should evaluate the operation of its new } \\
\text { enforcement powers relating to insider trading and manipulation } \\
\text { during the phase-in period to determine whether they are } \\
\text { achieving enhanced deterrence of misconduct. } \\
\text { - In this respect FSFM should develop appropriate } \\
\text { performance metrics relative to whether the remedies and } \\
\text { procedures are dissuasive and proportionate. }\end{array}$ \\
\hline $\begin{array}{l}\text { 10. The regulatory system } \\
\text { should ensure an effective and } \\
\text { credible use of inspection, } \\
\text { investigation, surveillance and } \\
\text { enforcement powers and } \\
\text { implementation of an effective } \\
\text { compliance program. }\end{array}$ & $\begin{array}{l}\text { - } \quad \text { FSFM should determine how best to measure and present } \\
\text { performance objectives and statistics for enforcement and related } \\
\text { monitoring activities. } \\
\text { - See also the comments under Principles } 4,6,7,8 \text {, and } 9 .\end{array}$ \\
\hline $\begin{array}{l}\text { 11.The regulator should have } \\
\text { the authority to share both } \\
\text { public and non-public } \\
\text { information with domestic and } \\
\text { foreign counterparts. }\end{array}$ & $\begin{array}{l}\text { Information sharing among domestic authorities may be } \\
\text { improved with the adoption of the Banking Law amendments } \\
\text { related to consolidated supervision and completion of a formal } \\
\text { protocol with the CBR (See Principle 1). } \\
\text { the clarification above and referred to in Principle } 8 \text { ) in its files } \\
\text { under a Memorandum of Understanding with appropriate } \\
\text { confidentiality protections to the same extent as such information } \\
\text { is obtainable by FSFM. } \\
\text { - FSFM should take steps promptly to meet requirements to } \\
\text { sign the IOSCO MMoU. }\end{array}$ \\
\hline $\begin{array}{l}\text { 12. Regulators should } \\
\text { establish information } \\
\text { mechanisms that set out when } \\
\text { and how they will share both } \\
\text { public and non-public } \\
\text { information with domestic and } \\
\text { foreign counterparts. }\end{array}$ & $\begin{array}{l}\text { - FSFM should consider whether the cross listing of securities, } \\
\text { through ADRs and GDRs, or as the basis of indexes, such as the } \\
\text { MSCI, favors the execution of additional specialist, bilateral MoUs. } \\
\text { - See Principle } 8,9,11 \text {, and } 13 \text {. }\end{array}$ \\
\hline $\begin{array}{l}13, \text { The regulatory system } \\
\text { should allow for assistance to } \\
\text { be provided to foreign } \\
\text { regulators who need to make } \\
\text { inquiries in the discharge of } \\
\text { their functions and powers. }\end{array}$ & $\begin{array}{l}\text { The FSFM should document its assistance activities. (See } \\
\text { also Principle 4) FSFM should support prompt adoption of changes } \\
\text { and/or clarifications that will expand its access to bank records and } \\
\text { move forward to become a fully signatory of the IOSCO MMoU. } \\
\text { - (See also Principles } 8 \text { and 11) }\end{array}$ \\
\hline
\end{tabular}




\begin{tabular}{|c|c|}
\hline Reference Principle & Recommended Action \\
\hline $\begin{array}{l}14 \text { There should be full, timely } \\
\text { and accurate disclosure of } \\
\text { financial results and other } \\
\text { information that is material to } \\
\text { investors' decisions. }\end{array}$ & $\begin{array}{l}\text { - FSFM should report on the extent to which ownership and } \\
\text { control reporting is in practice improving transparency and } \\
\text { protection of investors through disclosure. } \\
\text { Also, FSFM should evaluate the level of continuing } \\
\text { disclosure compliance and consider automating more of the } \\
\text { process. }\end{array}$ \\
\hline $\begin{array}{l}15 \text { Holders of securities in a } \\
\text { company should be treated in a } \\
\text { fair and equitable way. }\end{array}$ & $\begin{array}{l}\text { - Useful amendments have been made to seek better } \\
\text { ownership and control reporting (See Principle 14). The effect of } \\
\text { these amendments should be kept under review. } \\
\text { - FSFM now has power to review tender offer prices, and } \\
\text { should document how the pricing review methodology works in } \\
\text { practice. } \\
\text { r Management and Board members of issuers should be } \\
\text { required to disclose shareholdings even if they do not cross the } \\
5 \text { percent threshold. } \\
\text { - FSFM should consider what qualifications and oversight is } \\
\text { needed for independent evaluators, who currently are not required } \\
\text { to be licensed. } \\
\text { - Required "comply or explain" disclosure for public } \\
\text { companies as to the voluntary Code of good corporate governance } \\
\text { would improve the information provided to shareholders. }\end{array}$ \\
\hline $\begin{array}{l}\text { 16. Accounting and auditing } \\
\text { standards should be of a high } \\
\text { and internationally acceptable } \\
\text { quality. }\end{array}$ & $\begin{array}{l}\text { - FSFM should work with the Ministry of Finance and other } \\
\text { relevant authorities to determine the best way to (i) oversee } \\
\text { accountants and auditors, (ii) encourage prompt movement of } \\
\text { financial market participants and issuers to prepare for the } \\
\text { institution of IFRS, (iii) assure appropriate capacity/training among } \\
\text { the profession and within the regulator to implement the } \\
\text { accounting changes, and to (iv) move concomitantly to prepare a } \\
\text { plan to improve audit standards. }\end{array}$ \\
\hline $\begin{array}{l}17 . \text { The regulatory system } \\
\text { should set standards for the } \\
\text { eligibility and the regulation of } \\
\text { those who wish to market or } \\
\text { operate a collective investment } \\
\text { scheme. }\end{array}$ & - $\quad$ See Principle 21 below. \\
\hline $\begin{array}{l}\text { 18. The regulatory system } \\
\text { should provide for rules } \\
\text { governing the legal form and } \\
\text { structure of collective } \\
\text { investment schemes and the } \\
\text { segregation and protection of } \\
\text { customer assets. }\end{array}$ & $\begin{array}{l}\text { - FSFM should keep under review the sufficiency of available } \\
\text { information to determine whether the custodian of customer funds } \\
\text { is in fact unrelated to the management company and otherwise to } \\
\text { check on the proper custodianship and protection of customer } \\
\text { funds and the proper pricing of units of interest. } \\
\text { - FSFM should develop, as necessary, means to review on an } \\
\text { ongoing basis whether new models of CIS, such as ETFs, require } \\
\text { additional structural protections. }\end{array}$ \\
\hline
\end{tabular}




\begin{tabular}{|c|c|}
\hline Reference Principle & Recommended Action \\
\hline $\begin{array}{l}\text { 19. Regulation should require } \\
\text { disclosure, as set forth under } \\
\text { the principles for issuers, which } \\
\text { is necessary to evaluate the } \\
\text { suitability of a collective } \\
\text { investment scheme for a } \\
\text { particular investor and the } \\
\text { value of the investor's interest } \\
\text { in the scheme. }\end{array}$ & $\begin{array}{l}\text { If the Prudential Supervision Law, now in its second reading, } \\
\text { is adopted, FSFM should commit some responsibilities for } \\
\text { providing a complaints forum and overseeing conduct of business } \\
\text { affecting retail holders of CIS as well as individual retail investors } \\
\text { to the mandatory SRO for market professionals engaging in retail } \\
\text { business. } \\
\text { FSFM and the Russian Federation should promptly } \\
\text { effectuate the authority to establish an appropriate investor } \\
\text { compensation fund. (See also Principle } 24 \text { and 29). }\end{array}$ \\
\hline $\begin{array}{l}\text { 20. Regulation should ensure } \\
\text { that there is a proper and } \\
\text { disclosed basis for assets } \\
\text { valuation and the pricing and } \\
\text { the redemption of units in a } \\
\text { collective investment scheme. }\end{array}$ & $\begin{array}{l}\text { - FSFM should assess how well the pricing methodology for } \\
\text { illiquid securities functions in practice. (See also Principle 16). }\end{array}$ \\
\hline $\begin{array}{l}\text { 21. Regulation should provide } \\
\text { for minimum entry standards } \\
\text { for market intermediaries. }\end{array}$ & $\begin{array}{l}\text { - FSFM should promptly implement its plans for doing a } \\
\text { limited initial operational capacity due diligence on applicants } \\
\text { above a certain size. } \\
\text { - Once adopted, the Prudential Supervision Law will enhance } \\
\text { initial entry criteria, including for capital and internal controls, and } \\
\text { ongoing compliance capability. FSFM should assure that it has the } \\
\text { appropriate expertise and staffing to apply these new powers and } \\
\text { authorities (see Principle } 3 \text { ). }\end{array}$ \\
\hline $\begin{array}{l}\text { 22. There should be initial and } \\
\text { ongoing capital and other } \\
\text { prudential requirements for } \\
\text { market intermediaries that } \\
\text { reflect the risks that the } \\
\text { intermediaries undertake.. }\end{array}$ & $\begin{array}{l}\text { FSFM should institute specific early warning reporting to } \\
\text { relevant FSFM personnel by the exchanges and professional } \\
\text { market participants to permit prompt corrective actions to be taken } \\
\text { as necessary. } \\
\text { - FSFM should analyze whether current capital requirements } \\
\text { are sufficient to address the various risks set forth in IOSCO } \\
\text { standards, including credit, market, and operational risks, in } \\
\text { preparation for applying new authorities to be granted by the } \\
\text { Prudential Supervision Law. For example, FSFM should develop a } \\
\text { means to test the outcomes of market moves above a specified } \\
\text { size on capital. } \\
\text { Pending changes to capital requirements will require } \\
\text { adequate expertise to supervise and implement, including new } \\
\text { inspection regimes and procedures, which might reasonably focus } \\
\text { on identifying and prioritizing risks as well as random inspections } \\
\text { to ensure that books and records are current and that the capital } \\
\text { rules are being followed properly. }\end{array}$ \\
\hline $\begin{array}{l}\text { 23. Market intermediaries } \\
\text { should be required to comply } \\
\text { with standards for internal } \\
\text { organization and operational } \\
\text { conduct that aim to protect the } \\
\text { interest of clients, ensure } \\
\text { proper management of risk, } \\
\text { and under which management }\end{array}$ & $\begin{array}{l}\text { - The FSFM requires professional market participants } \\
\text { authorized by it to have compliance personnel. } \\
\text { - More capacity to oversee intermediary risk management will } \\
\text { be provided by introduction of the Prudential Supervision Law. } \\
\text { FSFM should assure that it has sufficient expertise in place to } \\
\text { conduct such assessments. (See also Principles } 3 \text { and 22) } \\
\text { Also, FSFM should exercise the power it receives from the } \\
\text { Prudential Supervision Law, when adopted, to cause the }\end{array}$ \\
\hline
\end{tabular}




\begin{tabular}{|c|c|}
\hline Reference Principle & Recommended Action \\
\hline $\begin{array}{l}\text { of the intermediary accepts } \\
\text { primary responsibility for these } \\
\text { matters. }\end{array}$ & $\begin{array}{l}\text { mandatory SRO for professional market participants dealing with } \\
\text { the retail public to develop more guidance on the implementation } \\
\text { of conduct of business principles, such as best execution and } \\
\text { marketing consistent with customer investment objectives. }\end{array}$ \\
\hline $\begin{array}{l}\text { 24. There should be a } \\
\text { procedure for dealing with the } \\
\text { failure of a market intermediary } \\
\text { in order to minimize damage } \\
\text { and loss to investors and to } \\
\text { contain systemic risk. }\end{array}$ & $\begin{array}{l}\text { The appointment of an authorized representative in } \\
\text { connection with suspension or revocation of a license or as part of } \\
\text { a temporary administration proceeding will facilitate the } \\
\text { management of a firm in distress. } \\
\text { - The adoption of the Prudential Supervision Law should be } \\
\text { progressed and implementation guidance for such representation } \\
\text { should be considered once the law is finally effective. } \\
\text { - The FSFM and the exchanges and other relevant financial } \\
\text { authorities should have contingency arrangements to deal with } \\
\text { market and firm disruption, making full use of their administrative } \\
\text { and information sharing powers. The FSFM should attempt to } \\
\text { determine in advance the steps of a wind-down plan. The plan } \\
\text { should contain (i) means to communicate with other regulators, } \\
\text { (ii) trigger points, such as changes in financial condition outside a } \\
\text { specific tolerance and reductions in capital, that are early warnings } \\
\text { and lead to initiation of prompt corrective action, and (iii) an } \\
\text { analysis of the available measures and tools to minimize customer, } \\
\text { counterparty and systemic risk. } \\
\text { - Any plan also should include the procedures for non-routine } \\
\text { communication with other regulatory authorities, including both } \\
\text { domestic and relevant foreign authorities-and for determining } \\
\text { whether market misconduct is related to financial issues in that } \\
\text { such misconduct sometimes obscures financial distress. } \\
\text { - Authority to establish an investor compensation fund should } \\
\text { be promptly implemented. }\end{array}$ \\
\hline $\begin{array}{l}\text { 25. The establishment of } \\
\text { trading systems, including } \\
\text { securities exchanges, should } \\
\text { be subject to regulatory } \\
\text { authorization and oversight. }\end{array}$ & $\begin{array}{l}\text { - The FSFM in authorizing new trading systems, or in } \\
\text { determining how to conduct ongoing oversight of merged markets, } \\
\text { should update and refine its audit and surveillance programs. } \\
\text { - Additionally it should use its new surveillance capability to } \\
\text { assess on an ongoing basis the appropriate parameters based on } \\
\text { experience with STRs or non-standard transactions (that may } \\
\text { indicate insider trading, market manipulation or other abuses) for } \\
\text { its own surveillance and for reporting by the exchanges or } \\
\text { organized markets. } \\
\text { to The different tiers of market structure should be transparent } \\
\text { ro customers; customers should be informed that the protections or } \\
\text { risks relative to different tiers of trading are different. } \\
\text { - See Principles } 17,21 \text {, and } 26 \text {. }\end{array}$ \\
\hline $\begin{array}{l}\text { 26. There should be ongoing } \\
\text { regulatory supervision of } \\
\text { exchanges and trading } \\
\text { systems, which should aim to } \\
\text { ensure that the integrity of } \\
\text { trading is maintained through }\end{array}$ & $\begin{array}{l}\text { - The FSFM should develop a metrics for evaluating } \\
\text { exchange performance of its compliance role and maintain } \\
\text { performance statistics. } \\
\text { - } \quad \text { See Principle } 25 .\end{array}$ \\
\hline
\end{tabular}




\begin{tabular}{|c|c|}
\hline Reference Principle & Recommended Action \\
\hline \multicolumn{2}{|l|}{$\begin{array}{l}\text { fair and equitable rules that } \\
\text { strike an appropriate balance } \\
\text { between the demand s of } \\
\text { different market participants. }\end{array}$} \\
\hline $\begin{array}{l}\text { 27. Regulation should promote } \\
\text { transparency of trading }\end{array}$ & $\begin{array}{l}\text { - The FSFM should keep under continuous review how price } \\
\text { reporting is conducted and whether there is a need to consolidate } \\
\text { pricing information on the market where the same product is listed } \\
\text { or admitted to trading in the same time zone. In this regard it } \\
\text { should take account of, or ask the exchanges to provide an } \\
\text { account of, the completeness and timeliness of information being } \\
\text { reported from OTC markets to the exchanges. } \\
\text { - The FSFM should also ask the new SRO for retail investors, } \\
\text { should the authority be granted, to study whether the number of } \\
\text { markets interferes with price formation and informs or confuses } \\
\text { investors as to risk and how best to address any such confusion. } \\
\text { - The exchanges and FSFM should keep abreast of } \\
\text { developments more generally about market structure and } \\
\text { protections and make needed adjustments in the related oversight } \\
\text { programs. }\end{array}$ \\
\hline $\begin{array}{l}\text { 28. Regulation should be } \\
\text { designed to detect and deter } \\
\text { manipulation and other unfair } \\
\text { trading practices. }\end{array}$ & $\begin{array}{l}\text { - The FSFM should develop programs to surveill or otherwise } \\
\text { to detect insider trading, manipulation and other market abuses } \\
\text { using its new real time information feed and other information such } \\
\text { as media reports. } \\
\text { - In this regard FSFM should determine whether the } \\
\text { definitions used and penalties assigned are achieving their } \\
\text { detection and deterrence objectives. } \\
\text { - To assist this process, FSFM should develop metrics for } \\
\text { measuring the performance of market operators and FSFM } \\
\text { surveillance systems in detection and deterrence (see also } \\
\text { Principle 25). }\end{array}$ \\
\hline $\begin{array}{l}\text { 29. Regulation should aim to } \\
\text { ensure the proper } \\
\text { management of large } \\
\text { exposures, default risk and } \\
\text { market disruption. }\end{array}$ & $\begin{array}{l}\text { The FSFM should develop approaches that enable it (i) to } \\
\text { determine where risks are originating in the market, (ii) to back test } \\
\text { risk reduction measures and sufficiency of existing risk } \\
\text { management at exchanges and financial market professionals, } \\
\text { and (iii) to follow up with other regulators in conducting appropriate } \\
\text { surveillance. } \\
\text { - There should be contingency plans to address both market } \\
\text { and firm disruption. } \\
\text { - As stated in Principles } 1 \text { and } 24 \text {, the FSFM should refine and } \\
\text { document its existing arrangements for cooperation with the CBR } \\
\text { with a view to further articulating the actions that can be taken to } \\
\text { address the default or failure of a professional market participant } \\
\text { or a market disruption through temporary administration, } \\
\text { instructions to market operators, or exercise of any other oversight } \\
\text { authority and to document how to address market abuse. } \\
\text { - Risk management and appropriate cooperation with the } \\
\text { exchanges on surveillance also should include understanding the } \\
\text { roles of each party in the event of a market disruption or firm }\end{array}$ \\
\hline
\end{tabular}




\begin{tabular}{|l|l|}
\hline \multicolumn{1}{|c|}{ Reference Principle } & \multicolumn{1}{c|}{ Recommended Action } \\
\hline & $\begin{array}{l}\text { failure before the fact. For example, FSFM should determine in } \\
\text { advance how to use any and all additional authorities granted in } \\
\text { pending legislation and conclude exemplary contingency } \\
\text { arrangements for various scenarios. }\end{array}$ \\
\hline $\begin{array}{l}\text { 30. Systems for clearing and } \\
\text { settlement of securities } \\
\text { transactions should be subject } \\
\text { to regulatory oversight, and } \\
\text { designed to ensure that they } \\
\text { are fair, effective and efficient } \\
\text { and that they reduce systemic } \\
\text { risk }\end{array}$ & $\begin{array}{l}\text { FSFM should request an assessment of its clearing infra- } \\
\text { structure once contemplated changes are implemented. } \\
\text { oversight of any CCP, including back testing, that takes advantage } \\
\text { of the new Clearing Law to assure that the risk management } \\
\text { regimes in place operate properly and that netting , margining and } \\
\text { related collateral and other risk mitigation arrangements provide } \\
\text { the level of default coverage required by international standards } \\
\text { (see also Principle 29). } \\
\text { - FSFM should also take steps to cause any CSD to meet the } \\
\text { requirements of the IOSCO/ Committee on Payment and } \\
\text { Settlement standards for securities settlement, payment systems, } \\
\text { and CCPs, and best practices of G-20 countries for central } \\
\text { securities depositories that apply to CIS investing offshore. }\end{array}$ \\
\hline
\end{tabular}

\section{Authorities' response to the assessment}

\section{The authorities found the detailed report comprehensive and useful and} welcomed advice on how to move forward on improvements, both pending and planned. Most of the FSFM's suggested enhancements and corrections are now incorporated in the text. In particular, the assessor has attempted to suggest how oversight of intermediaries might be strengthened in ways currently already in the planning process by FSFM. These include the enhancement of licensing procedures by adding on-site inspections and interviews to conduct due diligence on operational capacity and the development of contingency planning including appropriate cooperative protocols or memoranda of understandings with other financial authorities to address both financial and firm distress.

\section{To address FSFM concerns as to what should be next steps with respect to} clearing improvements; the assessor further recommended a more detailed assessment of the new clearing and CCP authorities obtained in 2011 after some period of experience with the development by FSFM of an oversight plan and early clarification of the realignment of all new authorities. FSFM has taken this under advisement.

\section{FSFM indicated its belief that the accessibility of the law, rules and legislation} affecting capital markets was sufficient and objected to the discussion of independence. The assessor did not concur, and concluded that an evaluation of the level of independence of the newly combined regulator's capital market oversight operation would require a period of experience with the new alignment of powers and accountability arrangements. 


\section{Detailed ASSESSMent}

\section{Table 3. Detailed Assessment of Implementation of the IOSCO Principles}

IOSCO requires the assessment of the effectiveness of implementation as well as the existence of a rule. Many new provisions have been adopted for which no period of performance is available. Implementation is then tested under the rules that previously existed to the extent possible.

\begin{tabular}{|c|c|}
\hline \multicolumn{2}{|r|}{ Principles Relating to the Regulator* } \\
\hline Principle 1. & The responsibilities of the regulator should be clear and objectively stated. \\
\hline Description & 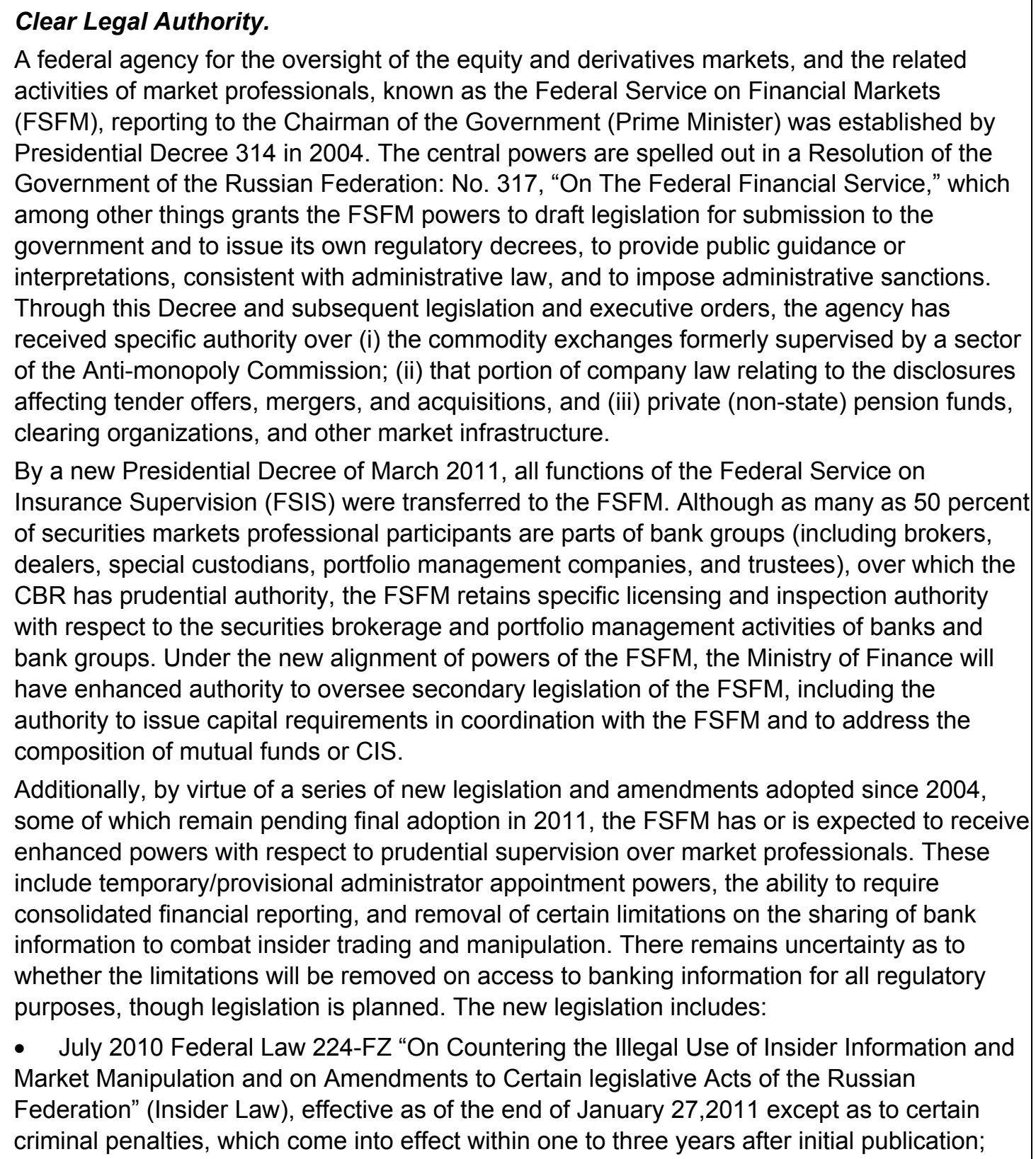 \\
\hline
\end{tabular}


- $\quad$ the "Federal Law on Clearing and Clearing Activities FZ-7" (Clearing Law) adopted February 7,2011 , which permits the creation and oversight of new clearing infrastructures, including central counterparties, which becomes effective January 2012, and related time concessions or amendments permitting consolidation of trading and clearing, some of which do not become effective until 2014; and,

- $\quad$ the draft law, "On Amendments to the Securities Law and to Certain Legislative Acts of the Russian Federation, now in its second reading before the Duma (Prudential Supervision Law).

Also of importance are amendments to the Banking Laws, which would further improve the ability of the competent Russian authorities to cooperate.

\section{Gaps and inequities.}

Panoply of laws and regulations

The powers of the FSFM appear to address, or will address when fully in force and implemented, all functional areas of securities regulation: that is, issuers, intermediaries, collective investments, secondary markets, clearing, and inspection, investigation and enforcement. The FSFM appears also to have been active in seeking to refine the design of its system to comport with the various areas addressed by IOSCO. Its core enabling legislation includes:

- On the Securities Market, FZ-39; and more area specific legislation, including:

- On Protection of the Rights and Legitimate Interests of Investors in the Securities Market, FZ-46;

- On Joint Stock Companies, FZ-208;

- On Investment Funds, FZ-156;

- The Code of Administrative Offenses of the Russian Federation, FZ-9;

- On Non-State Pension Funds, FZ-75;

- On Mortgage Securities, FZ 152, and

- On Amendments to the Securities Law, published October 10, 2010, which come into effect between January and March 2011, and

- $\quad$ On Insolvency, FZ-127 and relevant amendments concerning receivership and administration of financial market participants introduced by Law FZ-65 of April 22, 2010.

Addition of Insurance Powers.

As of March 2011, the FSFM has been given responsibility in the insurance sector by On Insurance, FZ-65.

\section{Modernizing and Keeping Abreast of Market Evolutions}

One objective of the current ongoing initiative of the President's Financial Council on creation of an international financial center is to improve the overall architecture of financial regulation and market infra-structure. The hope is to create "a more open, predictable, and improved investment climate," including appropriate judicial protection and protection of property rights. Too soon to judge effectiveness

As many of the legal enhancements are brand new, they have yet to be implemented, so while they have improved the overall framework or have the potential to do so, a full consideration of their effectiveness is not possible at this time.

Inconsistent Treatment

Certain investment funds managed by banks (BMMFs), supervised by CBR are operated under different rules from those that apply to investment pools (mutual funds) under the 


\begin{tabular}{|c|c|}
\hline & 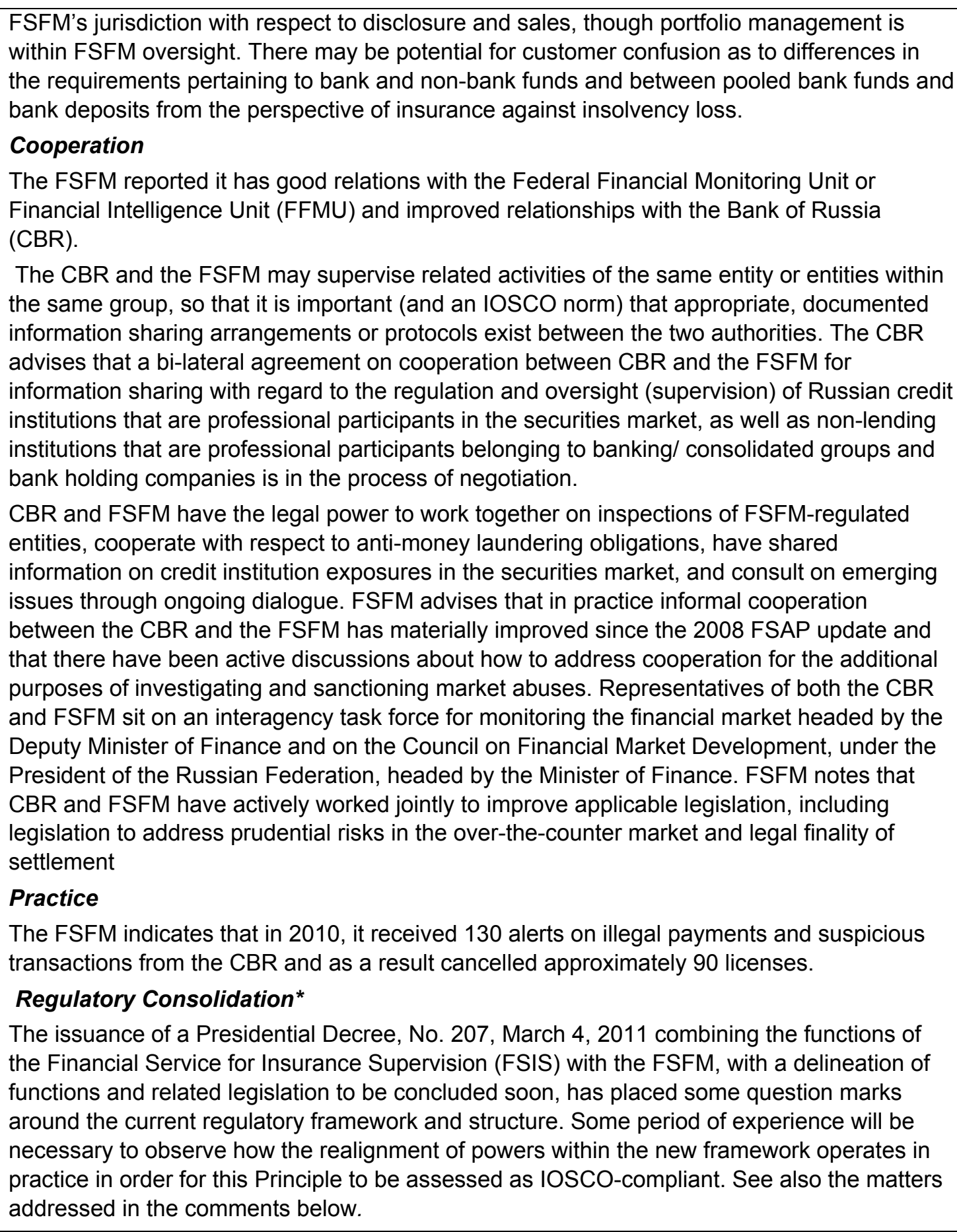 \\
\hline Assessment & Partly Implemented \\
\hline Comments & $\begin{array}{l}\text { Transition } \\
\text { While the current law clearly sets out the responsibilities of the FSFM, the law is in flux. As of } \\
\text { end June } 2011 \text { it was not yet clear how the functions of the FSFM would finally be assigned, } \\
\text { or reassigned, as the FSFM takes on its new functions with respect to insurance, and } \\
\text { possibly other non-banking financial activities, such as micro-finance, though it is expected } \\
\text { that the MoF will have expanded authority with respect to the development of applicable }\end{array}$ \\
\hline
\end{tabular}


capital requirements. The ultimate realignment of functions and accountability is not yet public and how it will operate in practice will require a period of experience and observation.

\section{Accessibility}

Although significant changes have been made to modernize and enhance the legislation affecting the FSFM, granting additional flexibility, providing for new products, addressing gaps, and augmenting powers, with the view to meeting international standards, the updated law should be more accessible to market participants and the general public. For example, efforts should be made on the website of the FSFM to clarify explicitly which portions currently are in effect. Assuring that all relevant laws and external regulations are available on the web site of the FSFM-ideally not only in Russian, but also in a language broadly used by its non-domestic market participants-would improve the overall transparency and comprehensibility of the system (See also Principal 4). Aggregating all the laws into one (perhaps virtually) indexed document would further improve accessibility. Pending reconstruction of the web site, some indication of why the former English site has been withdrawn (although there is an archive of the prior version) might be useful, such as words to the effect that: "the new site which reflects FSFM's new authorities is under construction." Although the archived website maintained in Russian currently can be accessed through the use of Google Translate, an official version would be preferable. Additionally, the actual texts of relevant legislation no longer appear to be linked to the Russian site. This creates uncertainty in the general public as to the status of the law. Most developed jurisdictions provide access to current law on a general government as well as a specific regulatory website.

\section{Cooperation with respect to oversight of the same or group entities}

Much progress has been made since the prior review in regularizing the cooperative activities of the FSFM and CBR, with respect to bank groups that conduct securities activities. Draft legislation would require that securities functions be carried out through a separate entity and to make bank information expressly accessible to the FSFM with respect to all bank deposits where a securities entity is part of the banking group or holding company. The assessment team has been advised that more concrete cooperative arrangements are in discussion. The FSFM and the CBR should undertake to conclude promptly a protocol or memorandum of understanding that identifies with particularity areas of common concern and sets forth the types of issues, products, and operations /methodologies (custodianship, clearing) relative to the supervision of securities firms and securities functions within, or products offered by, a banking entity and vice versa that should be subjects of collaborative efforts. In addition they should determine how best to share information relative to market abuses, and potential frauds, whether or not criminal authorities might need to also be involved in the case of the latter. Additionally, where not already conformed, pooled investment funds operated by banks should be subjected to the same rules as those under the FSFM's oversight.

The recent crisis demonstrates that risks can be transmitted from one sector to another. Discussions should be conducted between the FSFM, CBR and the Ministry of Finance, within the new task force or otherwise, to (i) address key risk identifiers/factors, (ii) determine where methods of oversight can be harmonized, (iii) share information on financial distress of firms, (iv) discuss risks that may be transmitted across sectors, (v) develop contingency arrangements, and (vi) further expand mechanisms to share market evolutions and related matters. While flexibility in handling potential firm or market disruptions is desirable, further thinking about potential risks and contingency planning among the authorities, including when and how to conduct joint inspections or further coordinate activities, would enhance the relationships necessary to continue to successfully address market and firm instability and to promote common action and harmonization when warranted (see also Principles 24 and 29). 


\begin{tabular}{|c|c|}
\hline & $\begin{array}{l}\text { More focus on these activities, which could be part of any financial markets-wide undertaking } \\
\text { to identify and mitigate potential systemic risks, would be consistent with IOSCO's } 2010 \\
\text { amendments to its Principles that require the development of a process to meet the systemic } \\
\text { risk objective appropriate to the FSFM's mandate. }\end{array}$ \\
\hline Principle 2. & $\begin{array}{l}\text { The regulator should be operationally independent and accountable in the exercise of its } \\
\text { functions and powers. }\end{array}$ \\
\hline Description & 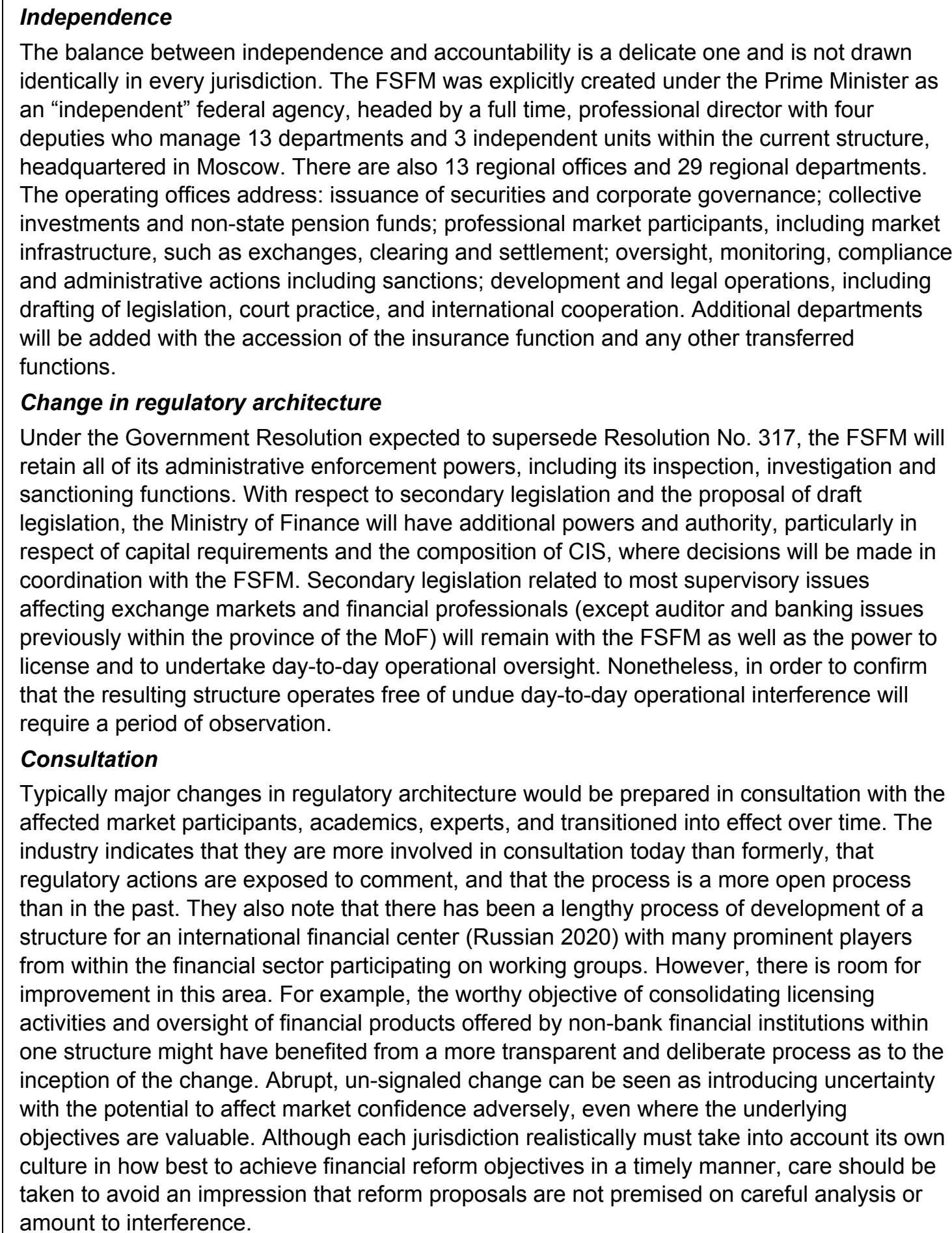 \\
\hline
\end{tabular}




\begin{tabular}{|c|c|}
\hline & 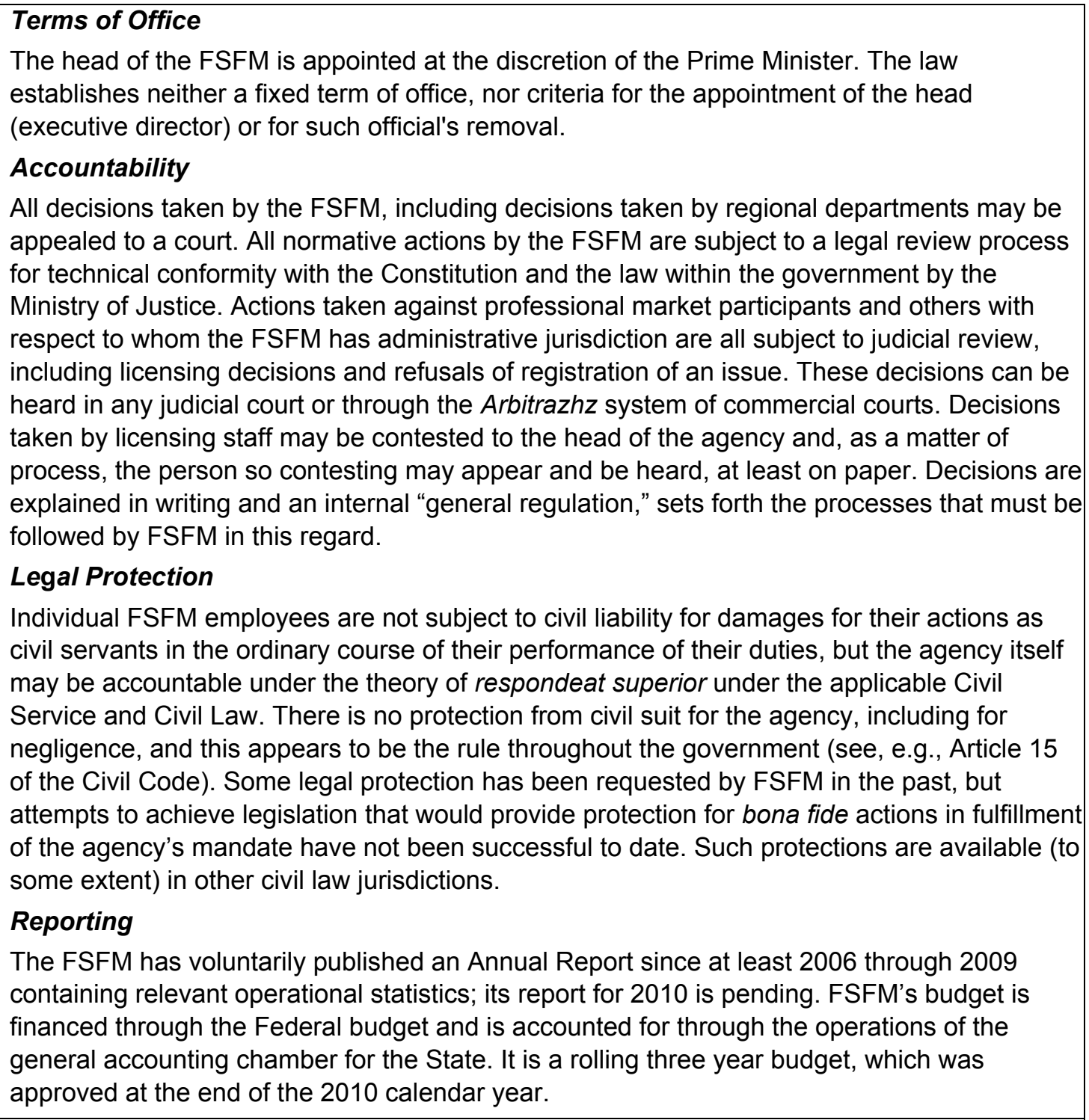 \\
\hline Asse & Partly Implemented \\
\hline Com & $\begin{array}{l}\text { Preserve normative powers and day to day operational control in new architecture } \\
\text { The ultimate alignment of the newly assigned and reassigned functions within the FSFM, and } \\
\text { the projected role of the Ministry of Finance in the agency's newly expanded operational } \\
\text { functions, remain a work in progress at this point in time. One concern is that the daily } \\
\text { operations of the agency could become subject to greater political scrutiny or possible } \\
\text { interference. Other issues expressed by the community pertain to whether the new structure } \\
\text { can be organized to build in sufficient consumer protection activities, particularly to address } \\
\text { all securities type investment products. } \\
\text { Terms of office, budget stability } \\
\text { The concerns expressed in previous reviews about independence also remain, in that there } \\
\text { continue to be no criteria for the appointment and removal of the head of the agency and staff } \\
\text { feel threatened by the overall government fiscal tightening that is currently pending. The } \\
\text { expressions "from the top," of a desire for greater certainty about predictable outcomes of the } \\
\text { regulatory system affecting financial markets and professional market participants, }\end{array}$ \\
\hline
\end{tabular}




\begin{tabular}{|c|c|}
\hline & $\begin{array}{l}\text { improvement of overall transparency and mechanisms for assuring the integrity of related } \\
\text { administrative processes are encouraging. A strategy to develop means to provide more } \\
\text { comfort in these areas will be welcome. In this regard it is important that the application of the } \\
\text { new structure be clarified publicly as soon as possible. } \\
\text { Legal protection of regulatory judgment } \\
\text { Although, the instances of suits against the FSFM are almost nil, the clarification of legal } \\
\text { protection for its bona fide actions, within the mandate, would avoid the possibility that } \\
\text { potential litigation would chill the ability of the FSFM to take significant regulatory actions, } \\
\text { such as to act to address issues related to winding down a firm or suspending its operations. } \\
\text { Further, to the extent that the regulator is required to make discretionary judgments and } \\
\text { adopts more risk-based, qualitative supervisory models, legal protection of the use of } \\
\text { discretion (absent a finding of bad faith) may facilitate the ability of the regulator to act, and to } \\
\text { prioritize actions, while preserving a mechanism to prevent inappropriate use of regulatory } \\
\text { powers. } \\
\text { The larger independence concerns though relate to the penumbra of remaining uncertainty } \\
\text { around the rearrangement of roles overall. }\end{array}$ \\
\hline Princ & $\begin{array}{l}\text { The regulator should have adequate powers, proper resources and the capacity to perform its } \\
\text { functions and exercise its powers. }\end{array}$ \\
\hline ption & $\begin{array}{l}\text { Powers and authority } \\
\text { FSFM, together with the Government, has made impressive recent progress in obtaining the } \\
\text { legislative enhancements to its powers and authority necessary to meet agreed international } \\
\text { standards, many of which changes have been under consideration for years. In this regard, } \\
\text { FSFM has sought, and appears to have achieved, a publicly stated commitment by the } \\
\text { President to take the essential steps to obtain those remaining information sharing and } \\
\text { cooperation powers and authorities to meet the standards set by IOSCO, which the G-20 } \\
\text { authorities have designated as particularly critical. } \\
\text { Recently adopted legislation: } \\
\text { - provides definitions of insider dealing and manipulation, } \\
\quad \text { expands inspection, investigation and sanctioning powers, } \\
\text { improves the capacity to determine ownership and control and } \\
\text { - provides enhanced wind-down and administration authorities and procedures. } \\
\text { Pending legislation will introduce further enhancements. } \\
\text { Additionally, FSFM has acquired the technical capacity and technology to conduct active, real } \\
\text { time surveillance of the markets for money-laundering compliance and the incidence of so- } \\
\text { called "non-standard" transactions (that may indicate insider trading or market manipulation) } \\
\text { and other securities violations or market abuses. } \\
\text { It also appears that additional activities, including some that are not currently regulated or } \\
\text { within the scope of the FSFM, will ultimately be integrated within its mandate, including for } \\
\text { example, micro-finance, mutual organizations, and additional over-the-counter transactions } \\
\text { or platforms. } \\
\text { Budget Sufficiency and Control } \\
\text { The Russian Web Site, http://www.ffms.ru, includes reports on results and operations, and on } \\
\text { budget expenditures and achievement of performance objectives, which would benefit from } \\
\text { further use of explanatory notes. FSFM is under the Federal budget and the fees and fines } \\
\text { collected go to the Treasury (Tax authorities) and do not directly fund the agency. Prior to the } \\
\text { inclusion of transferred FSIS personnel, there were } 356 \text { FSFM staff at headquarters and } 946 \\
\text { in the regions for a total of } 1302 \text {; after incorporation of the FSIS staff there will be } 476 \text { at }\end{array}$ \\
\hline
\end{tabular}




\begin{tabular}{|c|c|}
\hline & $\begin{array}{l}\text { headquarters and } 1116 \text { in the regions, for a total of } 1592 \text {, which number reflects, based on } \\
\text { current projections, a reduction of the staff allotment for FSIS. However, it is currently } \\
\text { projected that there will be a government-wide reduction in force by } 2013 \text {, such that at least } \\
250 \text { people will be lost to the FSFM, absent some budgetary adjustment. If full time staff were } \\
\text { reduced per the plan, the staff level for the new combined staff would be below levels } \\
\text { reported for the un-augmented FSFM in } 2008 \text {. } \\
\text { The FSFM submits a budget proposal to the Ministry of Finance; the budget is approved for a } \\
\text { rolling three year period, the most recent budget having been approved in } 2010 \text {. The FSFM } \\
\text { appears to have discretion in the deployment of its resources to functions and there is no } \\
\text { explicit evidence that the allocation of the budget is interfered with on an operational basis or } \\
\text { that reallocations are interfered with ex ante. } \\
\text { Workload There are approximately } 1800 \text { authorized professional capital market participants } \\
\text { (including brokers, dealers, asset managers, special custodians, registrars, and } \\
\text { depositories), more than } 10,000 \text { reporting issuers, } 2 \text { exchange groups (with multiple } \\
\text { markets), } 2 \text { settlement systems, and } 2 \text { clearing organizations currently projected to be in the } \\
\text { process of merging under a single umbrella by year end } 2011 \text {. Within the exchange groups, } \\
\text { certain markets have the status of organized market. There are also } 48 \text { registrars, } 150 \text { non- } \\
\text { state private pension plans, } 1461 \text { unit investment funds, and } 8 \text { joint stock investment } \\
\text { companies. Most of the large banking organizations also conduct securities functions. In } \\
2010,234 \text { prospectuses were registered and } 584 \text { licenses. } \\
\text { Budget Oversight and Process } \\
\text { The budget is subject, ex post, to general governmental audit, by the Chamber of Audit, for } \\
\text { purposes of audit and accountability. }\end{array}$ \\
\hline Assessment & Partly Implemented \\
\hline Comments & $\begin{array}{l}\text { The FSFM states that it views meeting the criteria for becoming a signatory to the Multilateral } \\
\text { Memorandum of Understanding and Cooperation and Information Sharing of IOSCO (MMoU) } \\
\text { as its top priority. FSFM should take steps to further prompt adoption of remaining needed } \\
\text { legislative change with respect to access to banking accounts, and to document by } \\
\text { undertaking or by other effective means where legislation is not required, needed } \\
\text { clarifications about its existing powers, where some reviewers have found ambiguities. (For } \\
\text { greater detail refer to Principles } 8 \text { to } 13 \text { below). There still remain some areas where, while } \\
\text { not required specifically by IOSCO, it might be more efficient if the FSFM had more power to } \\
\text { proceed directly and administratively rather than rely on making, and assisting referrals, to } \\
\text { the criminal authorities, for example to address securities fraud (which does not have a civil } \\
\text { component). } \\
\text { The planned creation of a new SRO which will be mandatory for firms doing client-facing } \\
\text { business with retail clients is intended to augment the ability of the FSFM to provide broad } \\
\text { and efficient protections to the public from conduct of business violations by licensed market } \\
\text { professionals. (See discussions under Principle } 8,13 \text {, and } 23 \text { ) This change would expand the } \\
\text { capacity of the overall regulatory structure to deliver these protections. } \\
\text { Structural changes } \\
\text { Care should be taken to assure that needed legislative changes continue to progress } \\
\text { efficiently, notwithstanding recent changes to the overall architecture of FSFM. } \\
\text { Pending system wide staff reduction } \\
\text { The prospect that the staff of the FSFM would be reduced under a general government-wide } \\
\text { program at the same time that it is being asked to undertake multiple new initiatives both to } \\
\text { improve market infrastructure and reliable performance and to augment its monitoring and }\end{array}$ \\
\hline
\end{tabular}




\begin{tabular}{|c|c|}
\hline & 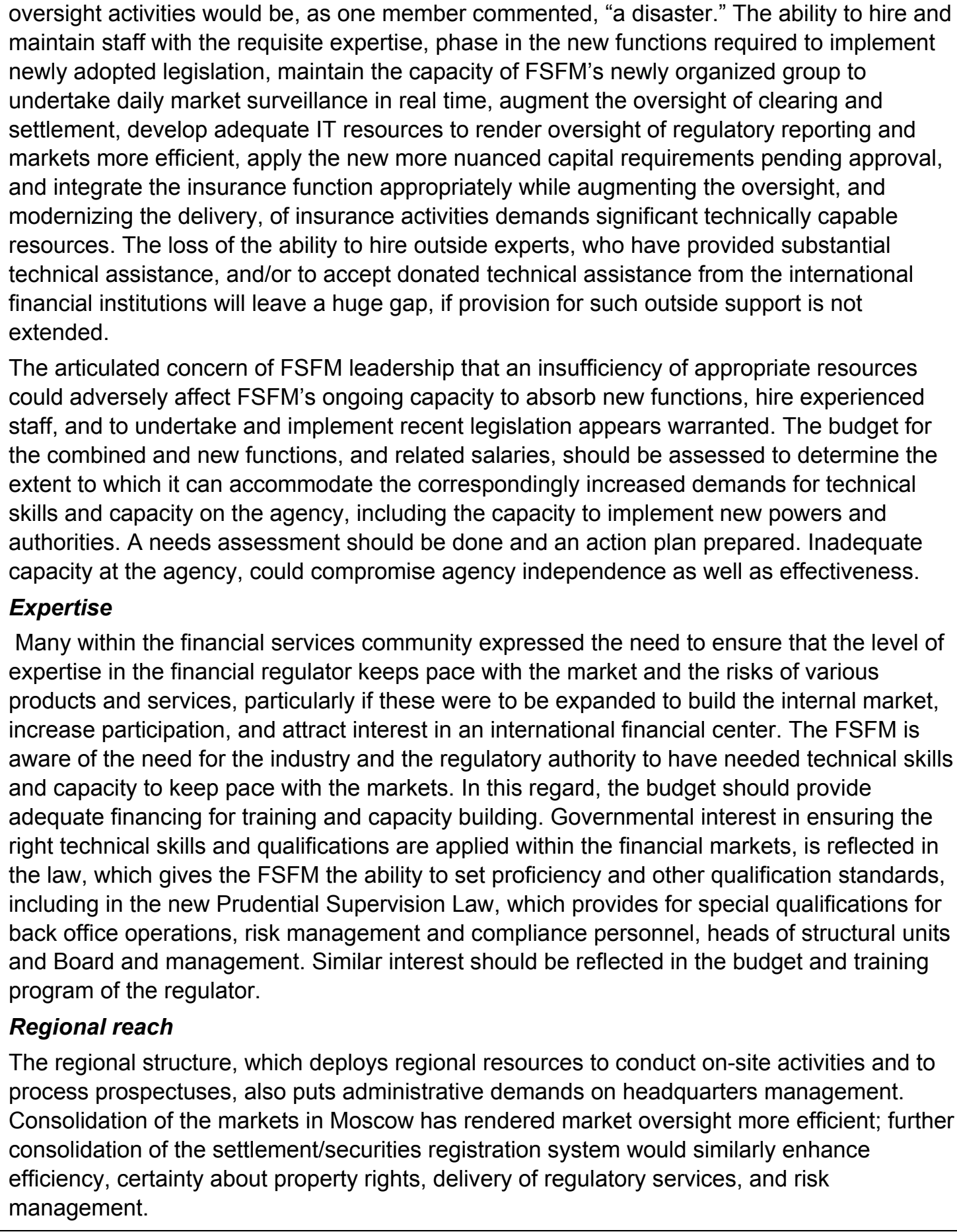 \\
\hline \multicolumn{2}{|l|}{ Principle 4.} \\
\hline Description & $\begin{array}{l}\text { Clear and equitable procedures. } \\
\text { The regulator is subject to administrative procedures, many of which are articulated in a } \\
\text { general Administrative Rule, dated July } 9,2009 \text {, No.09-26pz.Mr, which sets forth various } \\
\text { procedures and processes, the obligation of the FSFM to respond to public inquiries within a } \\
\text { set time frame ( } 30 \text { days), instructions for submission of documents, and procedures for } \\
\text { investigations, reviews and other internal operations. }\end{array}$ \\
\hline
\end{tabular}




\section{Consultations.}

Regulatory actions and orders are published on the website and in accordance with the Securities Law in the Official Gazette or Rossiyskaya Gazeta. All proposed rulemaking actions must be published for public notice and comment prior to adoption as a matter of law, and proposal notices must contain the reasons for undertaking the proposed action. Proposed or draft orders and regulations can be found on the FSFM website, but feedback statements on comments are not provided. The FSFM has the capacity to interpret provisions of the law in response to inquiries and must respond expeditiously. FSFM received 110 requests for interpretations of applicable securities law and regulatory requirements between January and May 2011. The various SROs, discussed in more detail in Principle 6, have been active in commenting on proposed legislation and rules. The new consumer union, a non-governmental agency, and other consumer bureaus may also engage in interactions with the FSFM as well as with the Duma, on various proposals, giving some voice to the retail public's concerns. The industry welcomes the opportunity to participate in comment, would like to see dialogue increase, and would welcome the use of feedback statements.

An examination of the general costs and benefits of regulation is part of the ongoing project launched by the President relative to the development of Russia as a financial center.

\section{Transparency and confidentiality.}

The general overarching Securities Law,FZ39 provides certain base-line fit and proper licensing criteria, including that an entity whose license is withdrawn by the CBR cannot be licensed by the FSFM and restrictions on reapplication after revocation or a financial failure for a specified time period. The draft Prudential Supervision Law, will also contain additional competency criteria for licensing. Further specific criteria are contained in regulations related to licensing, including:

- "Order of the Federal Financial Markets Service dated March 6, 2007 № 07-21/pz-n,"

"On approval of the licensing of professional activities in the securities market";

- $\quad$ Order of the Federal Financial Markets Service dated April 24, 2007 № 07-50/pz-n; "On approval of standards for adequacy of professional securities market participants, as well as management companies of investment funds, mutual funds and pension funds;" and - $\quad$ Order of the Federal Financial Markets Service dated 21 August 2007 № 07-90/pz-n "On approval of the Administrative Regulations of the Federal Service for Financial Markets of the state function of licensing of professional securities market participants."

- $\quad$ Further detail may be included in the Administrative Rules.

SROs, which currently are voluntary, but will become mandatory for professional market participants dealing with non-qualified (retail) investors upon adoption of the Prudential Law, may apply higher standards.

\section{Publication}

Rules, when adopted, by law, must be published in the official gazette, that is, the Rossiyskaya Gazeta. By custom they are also published on the FSFM's website, although the links to the text are not currently effective. Again, transparency and understanding would be facilitated by making all regulatory and legislative information more readily accessible (See discussion in Principle 1). Sanctions and licenses also are published on the FSFM website; investigations however are not made public as a matter of due process.

\section{Judicial Review}

All actions of the FSFM are appealable to the courts and thus reasons for such actions are provided and required by FSFM's internal regulation. Responses to public inquiries must be furnished in writing within 30 days as a matter of law. Additional rules relating to fairness and confidentiality apply to FSFM staff (see detail under Principle 5). 


\begin{tabular}{|c|c|}
\hline & 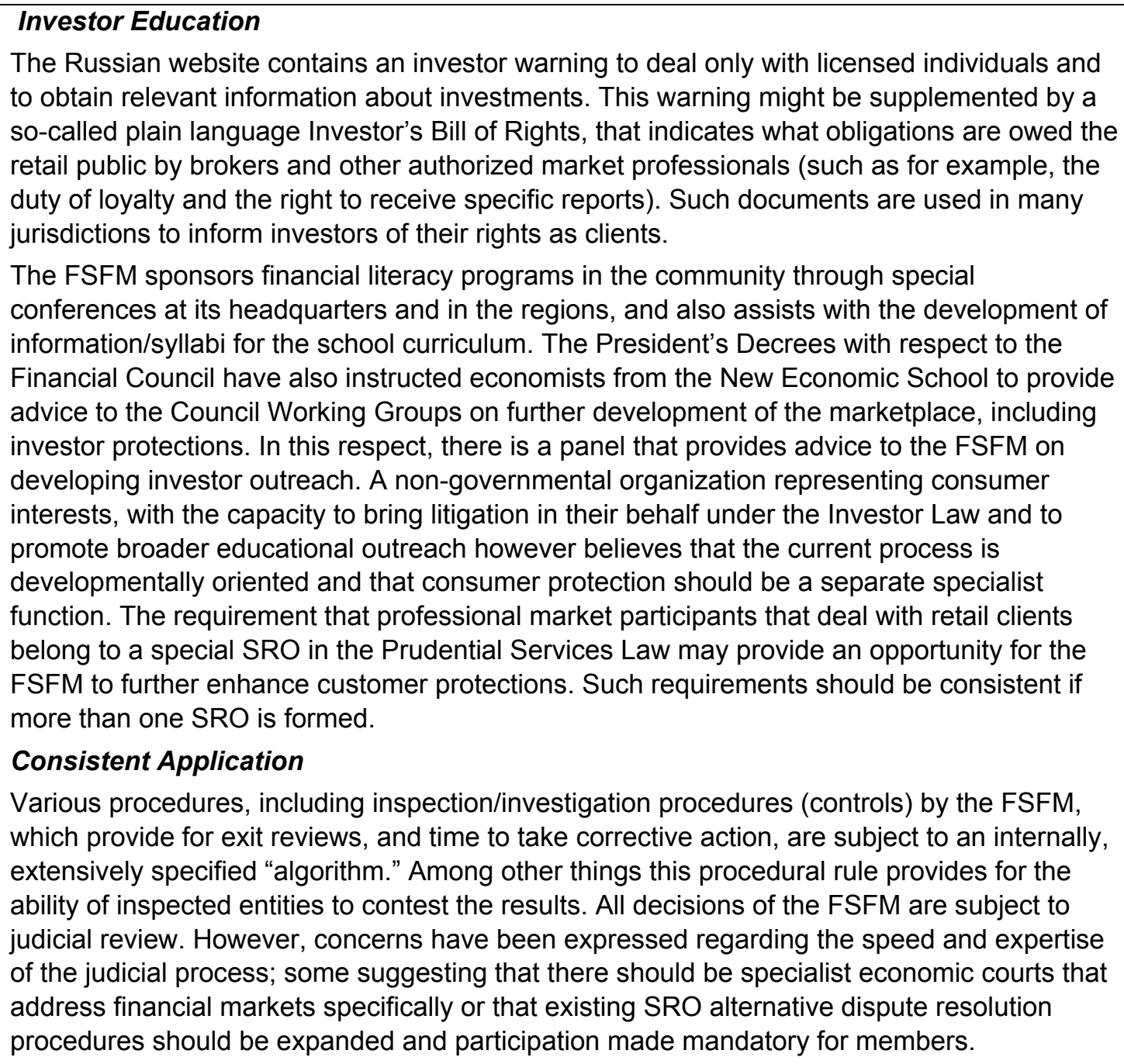 \\
\hline Assessment & Broadly Implemented \\
\hline Comments & $\begin{array}{l}\text { The consistency of regulatory action should be kept under review. Qualitative judgments are } \\
\text { part of the regulatory process; it is important that the regulated community perceive that rules } \\
\text { are applied in an equitable manner; such perception is in turn important to market } \\
\text { confidence. In this regard, interpretations of general applicability should be public. } \\
\text { To the extent the civil court system is overburdened, expansion of specialist alternative } \\
\text { dispute resolution forums to resolve securities claims might be explored, with appropriate } \\
\text { oversight of the framework by the FSFM and, qualification of properly representative } \\
\text { arbitration panels. Consideration could also be given to permitting the FSFM to hear appeals } \\
\text { of SRO and exchange disciplinary actions. The FSFM should consider publishing summaries } \\
\text { of comments received on proposed regulations and the regulator's responses to those } \\
\text { comments. Restoring ready access to available rules and regulations would also help } \\
\text { promote understanding of applicable rules and regulations by the growing investor public } \\
\text { especially if international expansion is a goal. Applicants/licensees should have an explicit, } \\
\text { transparent right to be heard on license applications }\end{array}$ \\
\hline Principle 5. & $\begin{array}{l}\text { The staff of the regulator should observe the highest professional standards including } \\
\text { appropriate standards of confidentiality. }\end{array}$ \\
\hline
\end{tabular}




\begin{tabular}{|c|c|}
\hline Description & 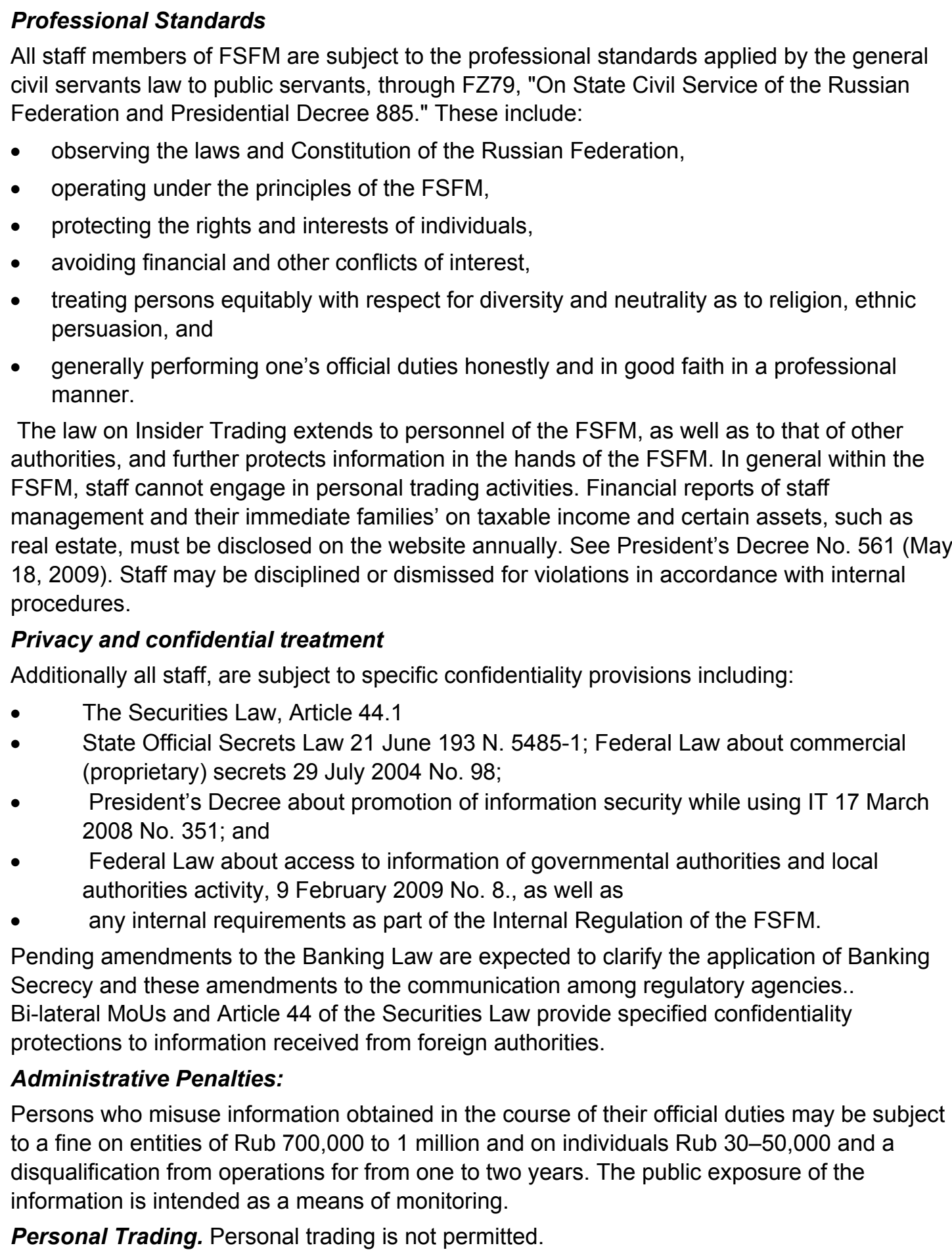 \\
\hline Assessment & Broadly Implemented. \\
\hline Comments & $\begin{array}{l}\text { In general, staff is subject to laws and administrative procedures that require professional } \\
\text { conduct, maintenance of appropriate confidentiality of sensitive information obtained in the } \\
\text { course of regulatory/supervisory duties, and avoidance of conflicts of interest. The law of } \\
\text { Insider Trading also makes government personnel subject to the Insider Law (see especially } \\
\text { Article } 4 \text { (10) and (9)), rendering the misuse of non-public information on professional market }\end{array}$ \\
\hline
\end{tabular}




\begin{tabular}{|c|c|}
\hline & $\begin{array}{l}\text { participants or issuers, with respect to tenders or take-overs, obtained from firm inspections, } \\
\text { with respect to licensing, or other information defined by the bodies or organizations } \\
\text { normative acts sanctionable. The law, however, is new and implementation regimes are in } \\
\text { the process of being designed in many areas. } \\
\text { FSFM should consider consolidating the applicable requirements in a Code of Conduct or as } \\
\text { a part of the Internal Code that could be made publicly available. It should also introduce } \\
\text { monitoring processes (see also Principle 2). }\end{array}$ \\
\hline \multicolumn{2}{|r|}{ Principles of Self-Regulation } \\
\hline Principle 6. & $\begin{array}{l}\text { The regulatory regime should make appropriate use of Self-Regulatory Organizations (SROs) } \\
\text { that exercise some direct oversight responsibility for their respective areas of competence, } \\
\text { and to the extent appropriate to the size and complexity of the markets. }\end{array}$ \\
\hline Description & $\begin{array}{l}\text { The use of SROs is not mandated by IOSCO; however if such SROs are used they must be } \\
\text { subject to adequate oversight as set forth under Principle } 7 \text {. } \\
\text { Definitions } \\
\text { As defined by IOSCO, SROs are organizations that establish rules which must be satisfied in } \\
\text { order for individuals or firms to participate in specific regulated activities, establish and } \\
\text { enforce binding rules of conduct for their mandatory membership, and may conduct } \\
\text { disciplinary proceedings. In that currently those institutions defined by law as SROs by the } \\
\text { Russian Federation are voluntary organizations, they are not, strictly speaking, for purposes } \\
\text { of Principle } 6 \text { (which post effectuation of the } 2010 \text { changes will be subsumed in Principle } 7 \text { ) } \\
\text { SROs. } \\
\text { Use within the Russian Federation } \\
\text { Russia has numerous entities that are authorized to be SROs. These are voluntary } \\
\text { associations that may be formed by } 10 \text { or more members and may facilitate regional } \\
\text { outreach activities; market professionals are not required to be members of any SRO, or any } \\
\text { particular SRO, as a matter of law. The existing authorized SROs include: } \\
\text { - the NAUFOR or National Association of Securities Dealers authorized in } 2004 \text {, with } 14 \\
\text { branches and a scaled membership fee; } \\
\text { - the National League of Management Companies or NP-NLU formed in } 2002 \text { with } 65 \\
\text { members, } \\
\text { - the National Securities Market Association (NFA) with } 235 \text { members formed in } 2003 \text {; } \\
\text { - the Professional Association of Registrars, Transfer Agents, and Depositories (PARTAD), } \\
\text { - with four offices formed in } 2003 \text {, } \\
\text { - the non-profit professional market participants association of the Urals or PUFRUR, and } \\
\text { - the National Association of Private (Non-State) Pension Funds (NANSPF), with } 75 \text { full } \\
\text { and } 35 \text { associate members, formed in } 2000 \text {. } \\
\text { All of these organizations have vested interests in normative actions taken by the FSFM and } \\
\text { may actively comment on proposals. } \\
\text { The objectives and characteristics of the SROs of the Russian Federation are more in the } \\
\text { organizations, though they do have the capacity to } \\
\text { provide dispute resolution and education, } \\
\text { - }\end{array}$ \\
\hline
\end{tabular}




\begin{tabular}{|c|c|}
\hline & 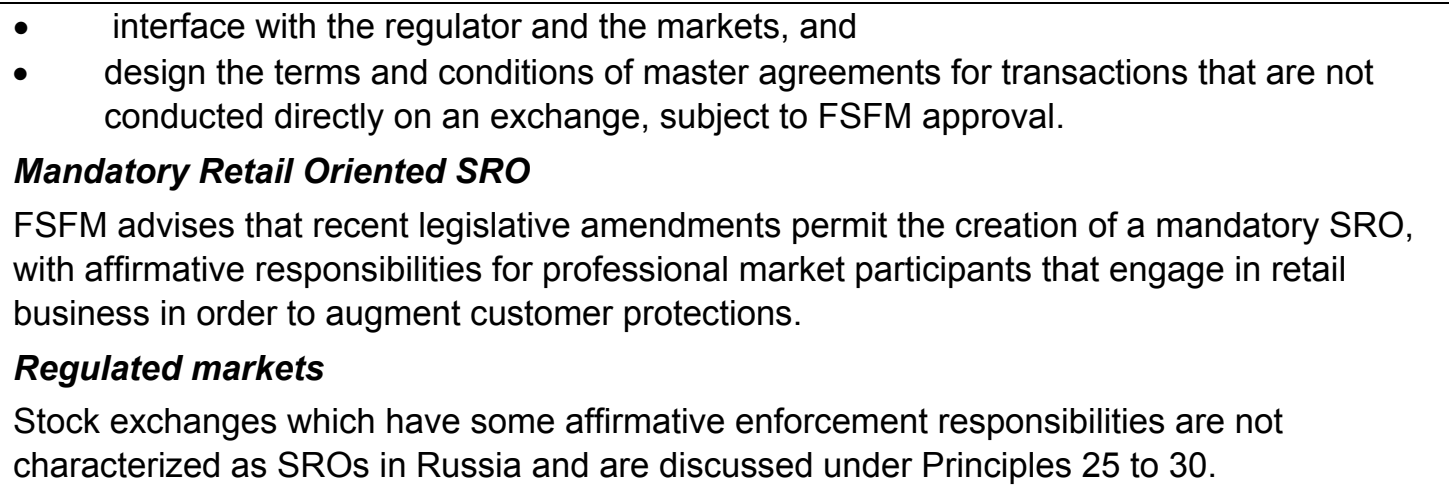 \\
\hline Assessment & Not Assessed \\
\hline Comments & $\begin{array}{l}\text { The use of a mandated SRO to expand the capacity of the regulatory system to deliver } \\
\text { conduct of business oversight should result in additional customer protections if properly } \\
\text { overseen. } \\
\text { This seems an appropriate way to augment the resources of the FSFM and to promote } \\
\text { dispute resolution and complaint resolution at less cost than through the court system. } \\
\text { The use of SROs generally to facilitate comment on regulatory and legislative initiatives and } \\
\text { to redress complaints and perform some member oversight has the potential to provide } \\
\text { effective feedback to the government from a number of different perspectives, to raise the } \\
\text { level of financial market proficiency and to appropriately augment governmental resources. } \\
\text { This Principle is rated 'not assessed' because IOSCO has determined no criteria exist for the } \\
\text { Principle and it is used for descriptive purposes only. }\end{array}$ \\
\hline Principle 7. & $\begin{array}{l}\text { SROs should be subject to the oversight of the regulator and should observe standards of } \\
\text { fairness and confidentiality when exercising powers and delegated responsibilities. }\end{array}$ \\
\hline Description & $\begin{array}{l}\text { Initial Authorization and Powers. } \\
\text { Self regulatory organizations must apply for permits/authorization under the core Securities } \\
\text { Law, FZ 39, and in the case of investment fund management company SROs, under } \\
\text { Investment Management Law FZ 156. The criteria for granting a permit are spelled out at } \\
\text { Article 50, which includes competency, record-keeping, the obligation to allocate all funds to } \\
\text { SRO activities, and other requirements. Under Article } 39 \text { SROs must be not-for-profit entities, } \\
\text { are entitled to develop binding rules of conduct and standards or best practices for their } \\
\text { members, and to undertake inspections, require member reporting, set "own funds" } \\
\text { requirements and undertake rule enforcement activities. These powers are further } \\
\text { augmented by the new Insider Law. For example, NAUFOR, the SRO for broker dealer firms } \\
\text { and that has over } 315 \text { members, indicates that it conducted } 70 \text { on-site inspections of its } \\
\text { members in } 2010 \text {. Article } 17 \text { permits the SRO to articulate rules applicable to its members } \\
\text { relating to preventing, detecting and deterring the illegal use of insider information and/or } \\
\text { engaging in market manipulation, }{ }^{3} \text { monitor the observance of members for violations of the } \\
\text { relevant Federal Law, related normative acts, and the rules of the SRO and establish } \\
\text { sanctions, and verify non-standard deals concluded with the participation of its members. } \\
\text { SROs have power under Article } 12 \text { of the Insider Law to demand information from their } \\
\text { members, including trading documents. Under Article } 49 \text { of the securities law, SROs also are }\end{array}$ \\
\hline
\end{tabular}

\footnotetext{
${ }^{3}$ The FSFM by regulation specifies what information/exception reports exchanges must provide with respect to non-standard transactions.
} 
entitled to receive confidential information on member inspections from FSFM.

An SRO can bar a participant from membership and apply to the FSFM to withdraw the member's license. An SRO can also hear investor claims and recommend that its members compensate claimants without a court proceeding; if an SRO fails to satisfy legitimate investor claims or to enforce the laws, the FSFM can apply sanctions to the SRO. Under Article 15 (2) of the Investor Protection Law, it appears that an SRO may act at its own initiative or be requested on application of the FSFM, other governmental bodies, and investors.

Under Article 50 there is a long list of requirements for granting an SRO charter and for refusing one. The reasons for refusing a charter are specified and do not include a catch all public policy clause. In order to change the charter or authorizing documents or rules of an SRO from those at the time of its authorization, the SRO must submit changes to the FSFM and if they are not refused within 30 days with a written explanation they will be deemed effective.

\section{Dispute resolution function}

Complaints by customers or members are heard by an SRO business conduct committee or disciplinary panel and are not appealable to the FSFM. Such appeals must be remitted to the judicial process. NAUFOR indicates that use of its arbitration process, whereby members can choose an arbitrator from a roster of arbitrators appointed by their Board of Directors, has gone from zero to 17 or 18 cases this year, indicating from the point of view of the leadership that the mediation process can be an effective complaint handling mechanism.

\section{Ongoing monitoring by FSFM}

SROs are overseen by the FSFM on an ongoing basis to determine, among other things, their continued compliance with the conditions of their authorization. In 2010, FSFM inspection staff undertook inspections of four national SROs. These followed a specified procedure on the conduct of inspections and the rights, methods, and obligations of the regulated entity and of the FSFM. Each inspection resulted in a written report, an exit conference with an opportunity to comment, and a time period to redress "exceptions," or to take other corrective actions. Inspection exceptions that are further investigated often relate to the filing of required documents with the FSFM, governance issues or other matters. FSFM also has the power to sanction an SRO, with the nuclear option of withdrawing its SRO license, although it has not done so.

\section{Cooperative Inspection Efforts}

FSFM indicates that it now has the power to conduct joint inspections with an SRO of that SRO's members and that it routinely invites the relevant SRO to participate. The SROs also may report misconduct to the FSFM, though this avenue is not now a major source of referrals to the FSFM. The inspection staff note that often the SRO and the FSFM may take joint or parallel action for misconduct.

\section{Professional conduct of SRO inspectors}

To be approved, SRO rules must provide for equitable treatment. Also, SROs, when acting to enforce their own and FSFM rules and standards, are required by their own rules to maintain the confidentiality of information received. IOSCO requires SROs to be subject to equivalent levels of professional conduct and confidentiality as the regulator. SRO confidentiality requirements should be express. In that the SRO, in inspecting its members at the instance of the FSFM, is performing a sort of quasi-governmental function; it may be that the provisions of the civil service code, if not already extended to such personnel, could be extended by rule. Under the Insider Law, while an SRO is not an insider, the confidentiality of information it received from its members should be protected under the Insider Law. See e.g, 


\begin{tabular}{|c|c|}
\hline & $\begin{array}{l}\text { Article } 4 \text { (5) of the Insider Law. } \\
\text { Governance } \\
\text { There do not appear to be governance requirements specific to SROs that are conditions of } \\
\text { licensing, but SROs are not at this point mandatory organizations that by denying access } \\
\text { deny the opportunity to conduct business. }\end{array}$ \\
\hline Assessment & Broadly Implemented. \\
\hline Comments & $\begin{array}{l}\text { Active cooperation } \\
\text { The FSFM has been active in developing some combined oversight programs with relevant } \\
\text { SROs, undertakes review of SROs within a three year cycle, and cooperates with SROs in } \\
\text { exchanging information on misconduct of licensed market professional members and on } \\
\text { inspections and actions to respond to the failure of such member participants to meet } \\
\text { regulatory requirements. The recommendation in prior reviews that the FSFM develop a } \\
\text { more collaborative approach with authorized SROs to expand the resources available to } \\
\text { address its regulatory responsibilities has been fulfilled, although the requirement of } \\
\text { mandatory membership that is before the Duma now would increase the ability of the SRO } \\
\text { process to increase the scope of the FSFM to deliver customer protections. Efforts to } \\
\text { increase cooperation with SROs in inspection and enforcement efforts should be continued. } \\
\text { Governance } \\
\text { The FSFM should consider whether additional requirements are necessary to address the } \\
\text { governance of SROS, particularly as membership becomes mandatory. } \\
\text { Consideration of a new Mandated SRO and related Oversight } \\
\text { The execution of rule enforcement responsibilities of exchanges and even of regulators are } \\
\text { being increasingly outsourced through regulatory services agreements. Any redesign, or } \\
\text { expansion, of the SRO program might take into account international benchmarks, such as } \\
\text { the approach of Europe, the US and Canada, and other models. }\end{array}$ \\
\hline \multicolumn{2}{|r|}{ Principles for the Enforcement of Securities Regulation } \\
\hline Principle 8. & The regulator should have comprehensive inspection, investigation and surveillance powers. \\
\hline Description & $\begin{array}{l}\text { Power Over Regulated Entities } \\
\text { FSFM has the authority to conduct on-site inspections of regulated entities' business } \\
\text { operations, including to inspect and copy such entities' books and records without prior notice } \\
\text { and to obtain and store information, including personal data, on persons. Securities Law } \\
\text { Article } 44 \text { (6) and (6.1). The Investment Fund Law, the Investor Protection Law, and the } \\
\text { Insider Law provide additional authority to obtain information. In general for routine reviews } \\
\text { that occur on a cycle, FSFM provides advance notice to its regulated entities. Where, } \\
\text { however, the inspection is prompted by a complaint, a market event, rumors, or by review of } \\
\text { financial filings or other disclosures, FSFM may inspect/investigate without prior notice on a } \\
\text { surprise basis. FSFM has full access to its licensed persons' books and records without the } \\
\text { need for judicial action. Books and records are required to be maintained for five years, } \\
\text { including per recent changes, the books of registrars and custodians. If not specified } \\
\text { explicitly, books and records would be required to be maintained under requirements in the } \\
\text { general law, such as the laws of taxation (a 10-year requirement). } \\
\text { Surveillance } \\
\text { FSFM also has the power to supervise its authorized exchanges' trading systems through } \\
\text { monitoring and surveillance and has recently constituted a surveillance team of } 20 \text { persons to } \\
\text { conduct the review of non-standard transactions and other trading information based on } \\
\text { alerts that are produced by its new surveillance technology. That system, NICE-Actimize, is a }\end{array}$ \\
\hline
\end{tabular}


real time data feed that was installed at FSFM at the end of 2010 to address AML/CTF and market abuse oversight. The staff of FSFM is obtaining experience with this new system and expects to be able to adjust the alert parameters more precisely to provide appropriate deterrence and detection of market abuses as it gains familiarity with the program's capabilities. Some additional types of surveillance routines will be necessary to address insider trading, such as observing the trading before and after IPOs or releases of information that may have an impact on price. The exchanges and other organized markets are also specifically tasked to oversee the market for non-standard transactions, and to file specified reports with the FSFM in addition to provide terminal access. The exchanges and organized markets can demand further information in this respect from their participants and the clients of their participants, including written responses and oral statements. (See Article 12, Insider Law; and Article 11 (1) and (2) of the Investor Protection Law) Professional market participants engaged in trading activities, and investment intermediation activities must also appoint compliance personnel to assist in meeting Federal requirements.

\section{Brokerage accounts and bank records}

FSFM has the authority to review broker trading records, including records with respect to individual clients. FSFM also can trace transactions through brokerage accounts to banking or depository accounts maintained by brokers' which must be legal entities, to settlement accounts at depositories, and to legal entity client's general bank accounts directly, in respect of potential, suspected insider trading or market manipulation by virtue of new legislation adopted in July 2010, which became effective January 27, 2011, after a multi-year effort. The FSFM has been given comprehensive authority to demand the provision of information needed to stop breaches of the Insider Law and normative acts adopted thereunder may further refine what information must be provided. If the matter concerns currency transactions, the FSFM must cooperate with the CBR. The ability to obtain natural persons' general banking records without a court order remains in doubt because although there is a general provision permitting the head of the FSFM to demand information from other agencies to address the law (see e.g., Article 14 (3)), there is a discrepancy between the banking authorities' and the securities authorities 'view of whether the recently amended banking law language is sufficient to address accounts of natural persons; and banking account access does not appear to be permitted for any securities law violation. There are pending changes to the Banking Laws which are expected to further clarify access to general bank records of natural persons by FSFM and the ability of the CBR to share banking records for oversight of all entities within a banking group or a bank holding company.

\section{Power to refer criminal offenses}

Certain offenses that are not administrative Securities Law offenses, such as fraud, must be pursued through the criminal justice system. This is also the case in some other jurisdictions. For this purpose, the FSFM may make a referral to the public prosecutor and may provide assistance. The Investor Protection Law appears to provide the authority for FSFM to suspend operations of a professional market participant if lack of cooperation were to jeopardize the rights and legitimate interests of investors and otherwise to order cessation of all violations of the securities laws.

\section{Client Identification}

The regulated exchanges require a specific client ID for transactions. Typically the exchange knows the broker and the broker' s direct customer, that is, the exchange, and correspondingly the FSFM, can see the identity of transactions though if the broker's client is a managed account or trust arrangement, then a review of the client's account would be necessary to determine underlying participation. However, in the case of cross border transactions, the ultimate clients are based in another jurisdiction and the net exposure may 


\begin{tabular}{|c|c|}
\hline & $\begin{array}{l}\text { be presented to the exchange in an "omnibus" account, while other transactions are } \\
\text { conducted internally in inventory by the foreign broker. A new law has been adopted to permit } \\
\text { the FSFM to see certain direct, and indirect, controlling persons behind the accounts of legal } \\
\text { entities, (FZ-264, which became effective in March 2011). This information also is relevant to } \\
\text { managing disruptions (see Principle 29). From the exchanges' perspective more authority in } \\
\text { this area should prevent liquidity from being diverted from the central market and enhance } \\
\text { transparency of trading in the market. These changes, with experience over time, should } \\
\text { strengthen the FSFM's ability to address misconduct and to see linkages in control. } \\
\text { Outsourcing regulation } \\
\text { At present the FSFM does not outsource or delegate regulatory processes to unlicensed third } \\
\text { parties. } \\
\text { Anti-money laundering } \\
\text { Regulated entities must comply with anti-money laundering provisions (FZ-115), and the } \\
\text { implementation of FSFM compliance programs are assisted by the Financial Intelligence Unit } \\
\text { (Federal Financial Monitoring Service) and the FSFM. In } 2009 \text { and } 2010 \text { this resulted in the } \\
\text { revocation of an unprecedented number of licenses (731) of seven different types. Anti- } \\
\text { money-laundering is reviewed pursuant to the FATF assessment methodology by FATF } \\
\text { assessors. } \\
\text { Inspections in Practice } \\
\text { In } 2009 \text { FSFM's headquarters inspection team conducted } 106 \text { inspections; } 90 \text { of which were } \\
\text { on-site and } 16 \text { of which were off-site. } 2010 \text { 's numbers were fairly similar. Most headquarters } \\
\text { inspections are of brokers, dealers and investment fund management companies. In the } \\
\text { territorial offices } 11,195 \text { inspections/ reviews were conducted of which } 1368 \text { were on-site and } \\
\text { the remainder of which were off-site. Regional oversight is largely directed to issuers. } \\
\text { Sanctions and orders/instructions flowing from the conduct of inspections/investigations are } \\
\text { posted on the FSFM website (see also Principle } 11 \text { ). } \\
\text { The FSFM aims to achieve yearly coverage of brokers. }\end{array}$ \\
\hline Assess & Partly Implemented. \\
\hline Comments & $\begin{array}{l}\text { Tremendous progress has been made by FSFM in securing the capacity to conduct effective } \\
\text { oversight of the market and market professionals. It can conduct inspections without notice or } \\
\text { judicial intervention. FSFM also has been granted broad authority to demand documents and } \\
\text { information from brokers, and by brokers of their clients, and to suspend operations for failure } \\
\text { to cooperate-a vigorous and prompt means of halting non-compliance, subject to further } \\
\text { investigation. The FSFM's authority with respect to insider information and potentially } \\
\text { manipulative conduct, or non-standard transactions, applies not only with respect to shares } \\
\text { but also can be obtained with respect to commodities, financial instruments, and currency } \\
\text { transactions. } \\
\text { The Russian Federation has moved forward to put in place laws and regulatory structures } \\
\text { that provide FSFM with a robust ability to mandate maintenance of needed records, prompt } \\
\text { access to those records and the ability to compel the production of records necessary to } \\
\text { properly enforce its rules against market misconduct from its licensees. FSFM must clarify its } \\
\text { ability, and process or gateways, to obtain banking records of natural persons for all } \\
\text { regulatory purposes (see also Principle 13). To the extent possible, FSFM should clarify any } \\
\text { remaining ambiguity as to the access to natural persons' general bank accounts either } \\
\text { through declarative action or by furthering legislative change. For example, it could clarify the } \\
\text { scope of Article } 26 \text { of the Banking Act, secure the adoption of pending CBR Banking Law } \\
\text { amendments, or try to address the issue by executing a protocol with CBR as to the access } \\
\text { to information needed for purposes of enforcing securities laws and related cooperative }\end{array}$ \\
\hline
\end{tabular}




\begin{tabular}{|c|c|}
\hline & $\begin{array}{l}\text { sharing as suggested under Principle } 1 . \\
\text { FSFM should also explain in its procedures how it investigates the ownership of nominee } \\
\text { accounts. } \\
\text { FSFM's expanded powers are new; therefore some time should be permitted to see how they } \\
\text { are implemented in practice as provided in the assessment of Principle } 10 \text {. The rating could } \\
\text { be improved to the extent the power to access such accounts can be demonstrated. } \\
\text { Caveat: if further constraints are introduced by the banking laws, then this could adversely } \\
\text { affect all the enforcement and information sharing ratings. }\end{array}$ \\
\hline \multicolumn{2}{|l|}{ Principle 9.} \\
\hline Description & 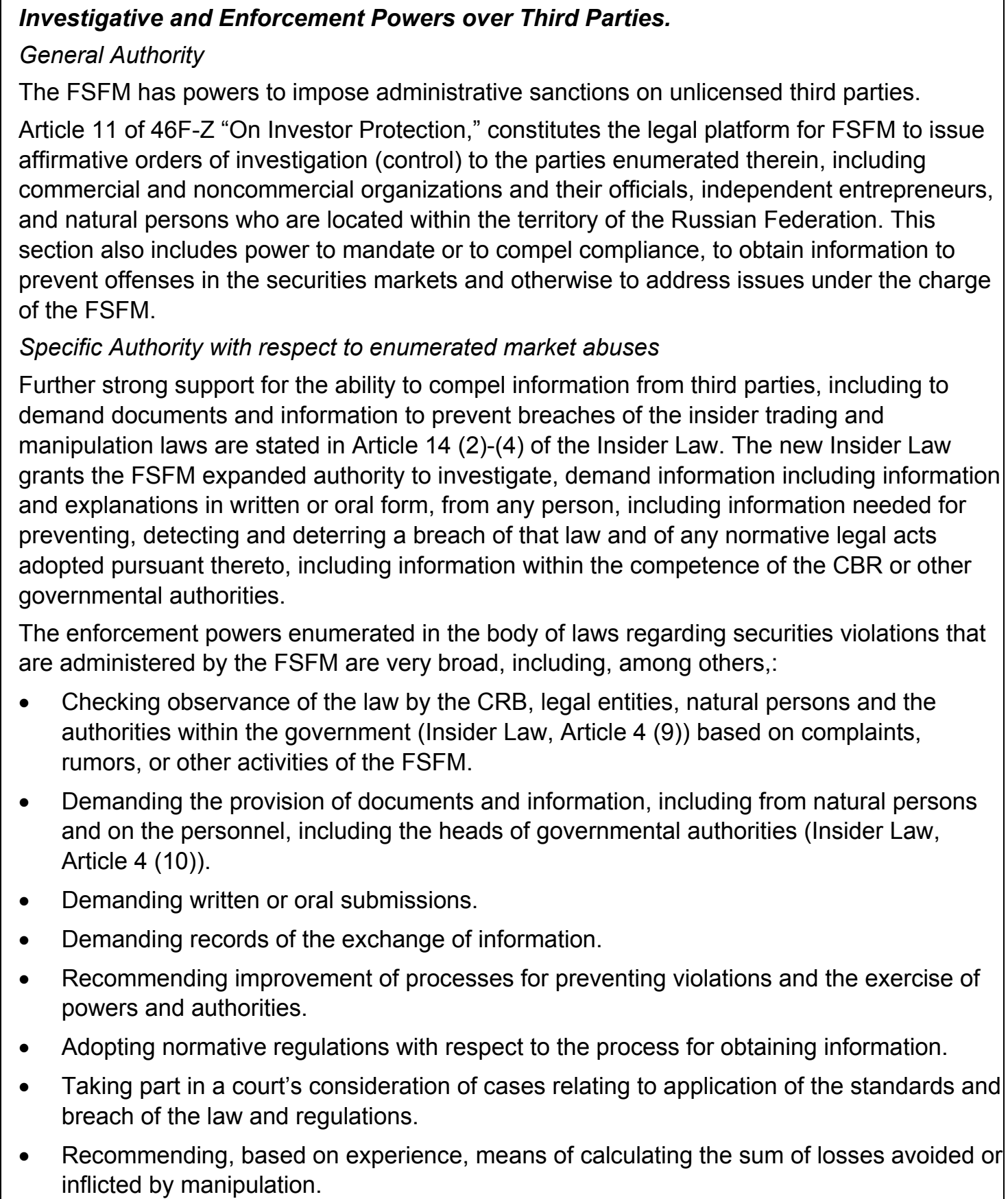 \\
\hline
\end{tabular}


- Suspending or revoking a license; filing a proposal to the CBR or other body in charge of licensing of a non-securities licensed entity to impose sanctions or to revoke or cancel a license.

- Suspending operations for failure to cooperate (e.g., Investor Protection Law).

- Issuing guidance on sanctions.

- Requesting investigative measures, including undercover investigations, telephone and IT records, through application to the Ministry of Internal Affairs.

- Engaging in cooperative enforcement efforts with several governmental authorities, including the CBR.

\section{Market abuse}

After decades of trying to pass the necessary legislation, the new Insider Law, and corresponding amendments to the Administrative Code of Offenses is effective as of end January 2011; it defines the market abuses of manipulation and insider trading, and makes them administrative as well as criminal violations. The criminal penalties will be phased in beginning in one and one-half years.

\section{Enforcement more broadly}

The FSFM has general powers under each of the several laws pertaining to the securities markets to seek and impose sanctions administratively, to cancel, suspend or condition licenses, to refer matters for criminal prosecution and to suspend trading in securities, cancel transactions and other actions, and to impose administrative fines. Among other new powers, FSFM now has the ability to appoint a temporary/provisional administrator (or receiver) under Section 4.1, Article 44 of the Securities Market Law, FZ-39, which can have in effect the result of freezing assets. Where necessary to collaborate with another domestic authority to address misconduct the FSFM may share information; however, FSFM is able to protect the confidentiality of information received from foreign authorities. Sharing must be in accordance with an MoU as a matter of law. FSFM can state how such information will be handled. It cannot share information received from a foreign authority in connection with such foreign authority's investigation to another person or authority without permission from the providing authority, absent a court order, and absent breach of a local provision. Insider Law (Article 15 (3) and Article 16 (6) and Securities Law Article 44 (12)) Fines have been increased but may still be relatively minor; in comparison to the gains potentially achieved by misconduct some may still see these as a cost of doing business. In the case of manipulation and insider trading there is the remedy of disgorgement of illegal gains as well as monetary fines. Further, creating sanctions materially strengthens the powers of the FSFM and also renders such misconduct subject to new reputational risks. Importantly, fines have been added that can be imposed on professional market participants for impeding an FSFM investigation or failing to produce information on request, including suspension of activities (Section 9, Article 15.29 of Administrative Code.) All securities law sanctions are also subject to compulsory disclosure. (Article 15 (1) Insider Law) (Article 44 (12), Securities Law FZ-39). Moreover, the ability to cause a party to cease operations for up to two years is a serious sanction; indeed some parties view "banning," as more significant than monetary penalties.

\section{Private rights of action}

The various laws also confer explicit private rights of action under the laws for injured parties to seek legal redress; and further empower (Investor Protection Law) SROs to file class actions. In the case of certain shareholder actions ,the FSFM is explicitly entitled to appear on behalf of investor protection, and otherwise to appear in court to support private claims, thereby potentially increasing the clout of public customers.

\section{Criminal cases}




\begin{tabular}{|c|c|}
\hline \multicolumn{2}{|c|}{$\begin{array}{l}\text { Criminal penalties under the Insider Law come into effect within three y } \\
\text { date of the law and include fines and imprisonment. The FSFM has clea } \\
\text { cases to the Public prosecutors for prosecution, and can assist the pros } \\
\text { (See Principal } 10 \text { on matters of implementation of these powers.) } \\
\text { Some examples } \\
\text { There is sufficient use of these powers to consider the powers to be in } \\
\text { has been commenced for manipulation. FSFM states that between } 200 \\
\text { headquarters conducted } 79 \text { investigations, including } 3 \text { of SROs, and the } \\
\text { following sanctions, resulting in multiple revocations as the result of a si }\end{array}$} \\
\hline LICENSE TYPE & REVOKED \\
\hline brokerage & 66 \\
\hline Dealer activity & 67 \\
\hline securities management & 64 \\
\hline depository activity & 24 \\
\hline registrars & 2 \\
\hline private pension fund & 3 \\
\hline management company & 9 \\
\hline specialized depository* & 2 \\
\hline
\end{tabular}

*investment fund custodian; some of operations may have been within the same entity

\section{Publication of sanctions}

All sanctions are made public.

\section{Assessment}

Comments

\section{Broadly Implemented}

The mechanisms are in place to demonstrate that there are a wide range of enforcement powers at FSFM's disposition. These powers are sufficient to permit the conduct of a materially enhanced enforcement program from that possible in 2008. However, the fining powers may not be sufficient to achieve the desired results. Evaluation of actual effectiveness of the enforcement program, including a consideration of all the remedies available, should be deferred pending some period of operation (See Principle 10) and the ability to observe the deterrent effect, including the extent to which penalties are dissuasive and proportionate. In this regard, the FSFM should develop more comprehensive performance metrics and statistics and make these public.

FSFM should continue to pursue augmentation of its enforcement authorities. While it works cooperatively and efficiently with the Ministry of Internal Affairs with respect to telephone and other records, FSFM might seek to ensure its specific authorities extend to obtaining any broker tapes and phone records through its brokers as opposed to the ISPs if this is currently in doubt.

Principle 10. The regulatory system should ensure an effective and credible use of inspection, investigation, surveillance and enforcement powers and implementation of an effective compliance program.

Description
The FSFM's categories of enforcement power are broad in scope and, under the menu of laws applicable to securities regulation there are a variety of remedies for investors and 
supervisory powers that cover each of the functions committed to FSFM oversight. For example:

- $\quad$ Principle 14: Signatories of quarterly annual reports are liable for their accuracy and FSFM has the power to refuse to authorize, suspend trading or halt trading in an issue; new pending laws are expected to impose fiduciary responsibilities on Boards of public companies; separately, the FSFM may intervene in a private shareholder action to support shareholders

- $\quad$ Principle 15: FSFM has the ability to review pricing, independence of the appraiser, and to suspend or prevent tender offers

- $\quad$ Principle 17, 19, 21, 25 and 26: FSFM has the powers to grant, deny, condition, suspend, and revoke licenses; Executive Board and Board members must not be subject to statutory disqualifications, such as having a criminal record or having been charged with economic crime within the past three years. These prohibitions also apply to persons that have an ownership interest in excess of 20 percent. The period of these bars might be revisited.

- $\quad$ Principle 17 and 21: FSFM regulations require that professional market participants have a compliance function.

- $\quad$ Principles 8 and 9: FSFM has the power to conduct inspections with and without notice on a routine and an ad hoc basis, and related powers to take and copy records, coupled with powers under an investigative/inspection order to demand information from any market participant. Inspection, surveillance and investigative activities are executed in accordance with an internal algorithm, with a flow chart that indicates the scope and process for conducting procedures of full and limited scope and the process for imposing sanctions.

- $\quad$ Principle 26 and 28: FSFM recently purchased and installed new technology to permit more effective and efficient oversight of the securities markets and new legal authority has augmented the FSFM's powers to address misconduct, by providing expanded powers with respect to manipulative practices, which are defined both broadly and specifically, and insider trading.

- $\quad$ Principle 22, 24 and 29: FSFM's new authority to deal with failing intermediaries, including the ability to impose a temporary/provisional administration or receivership on a licensed firm which were just granted in 2010 effectively permit the freezing of assets. Also new technology has been acquired to permit the more efficient processing of alerts, and new alerts are in the course of being designed in conjunction with the FSFMs new corrective/intervention powers. The pending Prudential Supervision Law will also permit an authorized representative from FSFM to approve transactions within an entity whose license has been suspended or withdrawn or while a firm is being wound down.

- $\quad$ Principle 23: Intermediaries are required to have qualified personnel who operate a compliance function, and FSFM has ability to check their activities in the course of on-site inspections. FSFM is expanding the review process for authorizing professional market participants to include on-site due diligence in appropriate cases.

\section{Inspection Coverage}

Inspections of issuers represent 70 percent of the inspections performed, some of which are performed by records review. The emphasis in such cases is on disclosure requirements, requirements for an annual meeting, including the timeliness of notice, appropriate notices to shareholders, voting records, and compliance with the requirements on related party transactions. The inspections of professional market participants, such as brokers, dealers, exchanges, SRO's and investment fund managers, for which full scope procedures are performed on an approximate three-year cycle, are usually conducted by headquarters. 


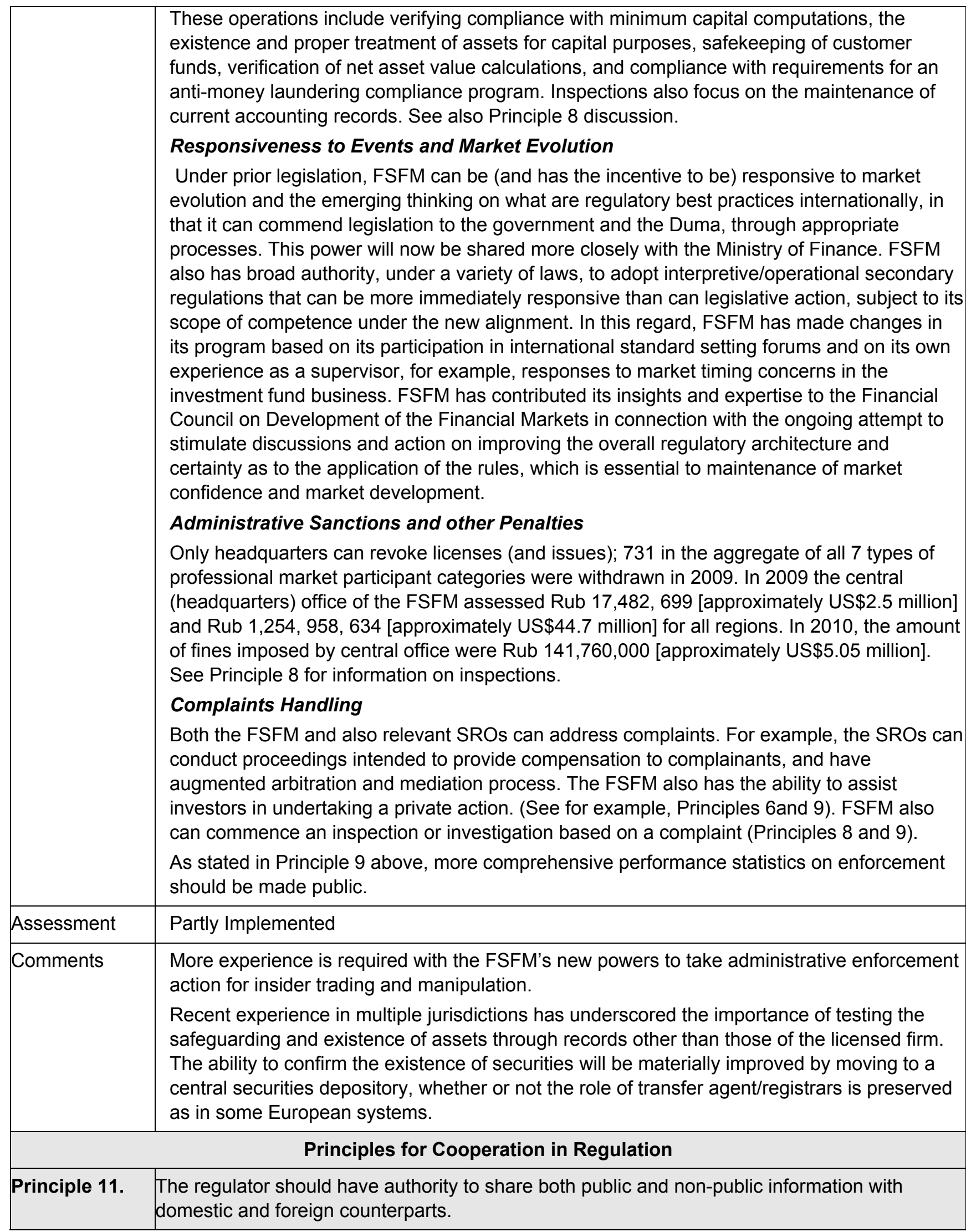




\begin{tabular}{|c|c|}
\hline Description & 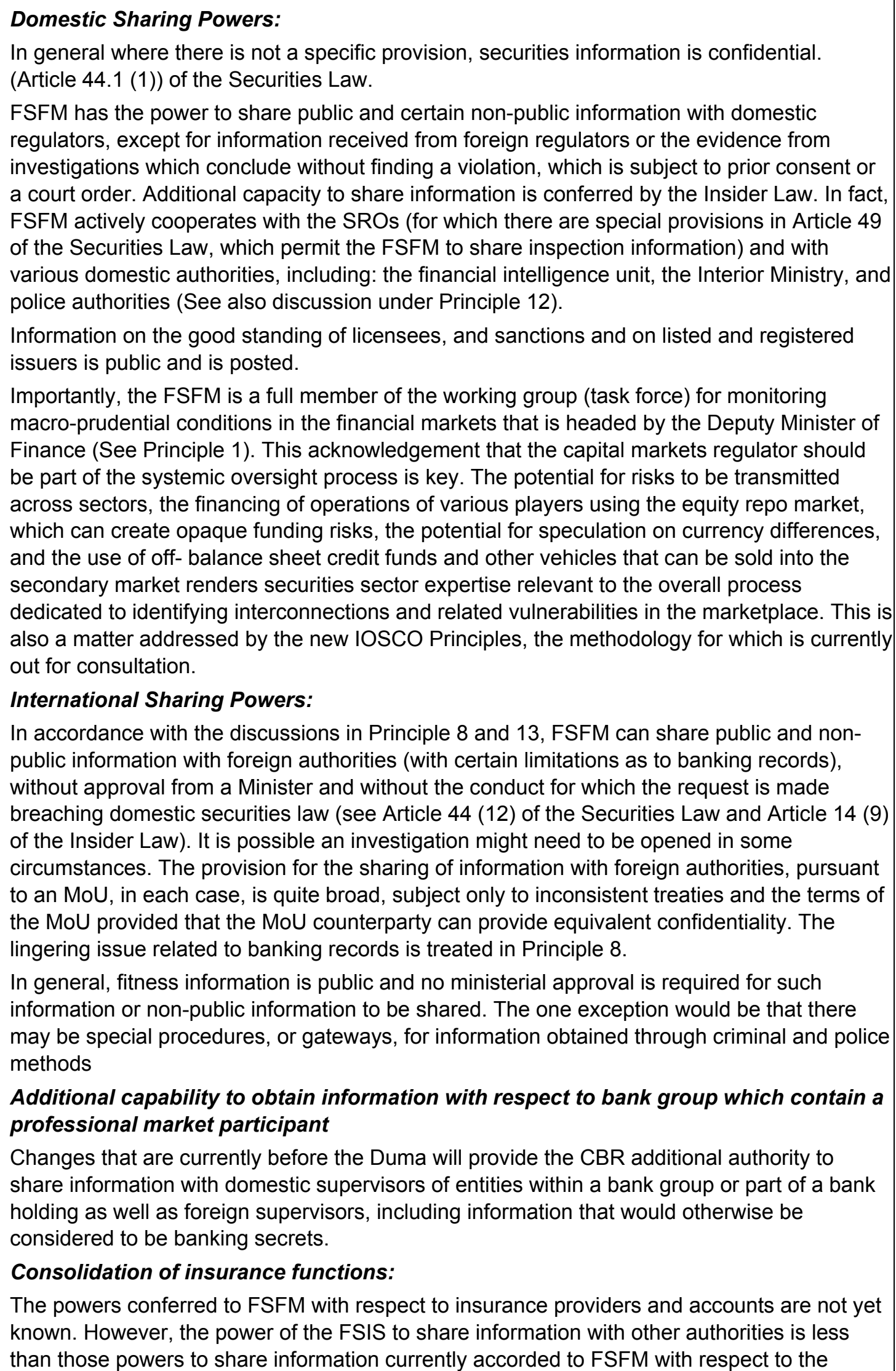 \\
\hline
\end{tabular}




\begin{tabular}{|c|c|}
\hline & $\begin{array}{l}\text { financial market participants and markets and products it regulates and oversees. To the } \\
\text { extent any insurance products are similar to collective investments the rules should be the } \\
\text { same as for securities more generally. }\end{array}$ \\
\hline Assessment & Broadly Implemented \\
\hline Comments & $\begin{array}{l}\text { Additional capacity to receive banking information from the CBR by the FSFM, as } \\
\text { contemplated in amendments to the Banking Act (especially Article } 26 \text { and } 51 \text { ), before the } \\
\text { Duma and with respect to Consolidated Supervision, have the potential to materially enhance } \\
\text { the extent to which information can be shared among the authorities for remedial, audit, and } \\
\text { enforcement purposes. } \\
\text { As discussed in Principles } 1 \text { and 12, documenting in writing the arrangements with } \\
\text { commonly contacted domestic counter-parties should be progressed. This is especially true } \\
\text { in that new IOSCO Principles will require the securities regulator to demonstrate a process } \\
\text { for addressing systemic risk appropriate to its mandate. } \\
\text { Although there could be some question as to whether Article } 16 \text { (6) of the Insider Law could } \\
\text { be read to limit the power of Article } 4 \text { (9) of that law which gives broad power to the FSFM to } \\
\text { share non-public information with foreign authorities in regard to breaches related to } \\
\text { manipulation and insider trading, it should be possible to clarify that such a reading is not } \\
\text { intended.. The traditional rule of legal construction is that particular language should prevail } \\
\text { over general language. Additionally, Article } 16 \text { (6) appears directed to requests related to } \\
\text { possible insider dealing or manipulation violations by personnel of government authorities as } \\
\text { listed in Article 4(9). Such information generally would be protectable from discovery under } \\
\text { an arrangement with a foreign authority under a provision relating to exceptions for national } \\
\text { interest, executive privilege or other similar claim in many jurisdictions.. FSFM should make } \\
\text { explicit by guidance or declaration as to how it interprets the law. }\end{array}$ \\
\hline
\end{tabular}

Principle 12. Regulators should establish information sharing mechanisms that set out when and how they will share both public and non-public information with their domestic and foreign counterparts.

\begin{tabular}{|l|l} 
Description & The FSFM indicates that it has in practice shared information internally with domestic
\end{tabular} authorities, subject to certain confidentiality limitations on its ability to share information received from non-domestic authorities, and that it also has found pragmatic ways to share information internationally to assist foreign authorities, even where all the formal requirements—such as an $\mathrm{MoU}$-were not in place, citing exchanges with the US Securities and Exchange Commission, for example, with whom the previous capital markets authority had an MoU, which ideally would be re-executed.

\section{Domestic Sharing Arrangements}

Formal arrangements or protocols exist between the FSFM and the Financial Intelligence Unit, and the following other domestic authorities: Ministry of Internal Affairs, Federal Antimonopoly Service, Federal Service for Financial Monitoring, and Federal Service of Court Bailiffs. The ability to cooperate with the CBR with respect to bank groups is planned to be materially expanded by the pending banking amendments.

During the recent crisis, the CBR and the FSFM developed practical operating methodologies for cooperating including working arrangements to share inspection information.These arrangements have not been documented. An MoU between CBR and FSFM has reportedly been in negotiation since the 2003 assessment. In that as much as 50 percent of the participants in the financial markets are credit institutions or part of bank groups, the lack of more particularized protocols could be destabilizing in the event of further market disruption. The engagement that is achieved through the underlying dialogue and networking that necessarily must precede agreement on such a protocol would also enhance the working 
relationships between the regulators. Such a protocol could also facilitate enforcement information sharing in that it could contain agreed formats for exchanging information on bank records under article 18(5) of the Insider Law. The execution of such arrangements and accompanying discussions also can result in beneficial informal exchanges relative to identification of the key factors that might cause risks to migrate from one sector to another, and as to what information is critical to either the bank or the FSFM in managing such a situation. See also the discussion under Principles 1, 24, and 29.

\section{International Sharing}

The FSFM has the authority to share any information, including personal data, within its files (except that received from foreign authorities, for which consent or a court order is required). (See discussion in Principle 8 and Principle 11). In order to share non-public information with a foreign counterpart, the law requires that FSFM have executed a memorandum of understanding, the information in the hands of the non-domestic authority must be treated with equivalent confidentiality, and that the information is exchanged pursuant thereto. Currently bi-lateral arrangements exist with the following fifteen jurisdictions: Belarus (Ministry of Finance of the Republic of Belarus); Brazil (Securities Commission of Brazil); Venezuela (National Securities Commission of Venezuela); Germany (Federal Financial RegulatorBaFin); India (The Council of the Securities and Exchange Commission of India); Cyprus (Commission of the Securities and Exchange Commission of the Republic of Cyprus); Kyrgyzstan(Supervision and Financial Regulator of Kyrgyz Republic); China (Chinese Securities Regulatory Commission); Korea (Financial Services Commission of Korea); Liechtenstein (Office of Financial Markets, Liechtenstein); UAE (Commission on Securities and Commodities UAE); Sultanate of Oman (Main Committee on the Stock Market (CMA)); Syria (The Commission on Financial Markets and Securities of Syria); Turkey (Financial Markets Commission, Turkey); France (l'Autorité des marchés financiers or AMF). There also is a joint letter with the USCommodity Futures Trading Commission (CFTC). FSFM is presently working on a project with the European Union, through the European Securities Supervisory Markets Authority (ESMA).

FSFM, and the Russian Federation, have as a first priority, execution of Annex A to the IOSCO Multilateral Memorandum of Understanding on Information Sharing and Cooperation (IOSCO MMoU). Russia is currently a signatory to Annex $\mathrm{B}$ and is in the process of preparing to reapply, having secured substantial legislative changes to strengthen its bid for full membership.

Some notices from a formality perspective are required to be made to the Ministry of Foreign Affairs with regard to executing MoUs, but these are not inhibitory, and are replicated in many other countries.

\section{Accessibility of public fitness information}

Information on sanctions of licensees and other persons is posted on the FSFM website and hence can be consulted easily by foreign regulators with respect to fitness determinations to be made in those other jurisdictions.

\section{General Participation in the International Community:}

Russia participates on the Financial Stability Board; is an ordinary member of IOSCO; acts as an observer on several OECD working groups relating to corporate governance and financial markets, and is applying for more formal recognition; FSFM also sits on FATF; participates in the International Institute for the Unification of Private Law (UNIDROIT) which addresses insolvency regimes and indirect securities holding systems, among other international initiatives and committees. 


\begin{tabular}{|c|c|}
\hline & $\begin{array}{l}\text { The details of the exchange of information with other authorities under an MoU typically are } \\
\text { themselves non-public information and as such are confidential. Nonetheless, it is important } \\
\text { to note that the FSFM does actively cooperate when requested. For example, FSFM has } \\
\text { recently cooperated with the Cyprus Securities and Exchange Commission. FSFM should } \\
\text { develop improved performance statistics and logs on requests received and made, issues } \\
\text { with implementation encountered, and how these were disposed of. }\end{array}$ \\
\hline Assessment & Implemented \\
\hline Comments & $\begin{array}{l}\text { Prompt restarting of the application process for accession to the MMoU is recommended. } \\
\text { Even after signing the MMoU is accomplished, the benefits of more specific bi-lateral } \\
\text { agreements should be considered for specialist issues, such as cross-listed/traded securities, } \\
\text { common financial markets in commodities and so forth. For example if Russian securities are } \\
\text { cross-listed or deposit receipts are traded in other jurisdictions, ideally FSFM should have } \\
\text { information sharing arrangements with such jurisdictions. } \\
\text { Conclusion of more formal arrangements with the CBR is a pressing matter, which has been } \\
\text { pending overlong. This is reflected in the rating under Principle } 1 \text {. Active efforts should be } \\
\text { taken to progress this initiative. }\end{array}$ \\
\hline Principle 13. & $\begin{array}{l}\text { The regulatory system should allow for assistance to be provided to foreign regulators who } \\
\text { need to make inquiries in the discharge of their functions and exercise of their powers. }\end{array}$ \\
\hline Description & 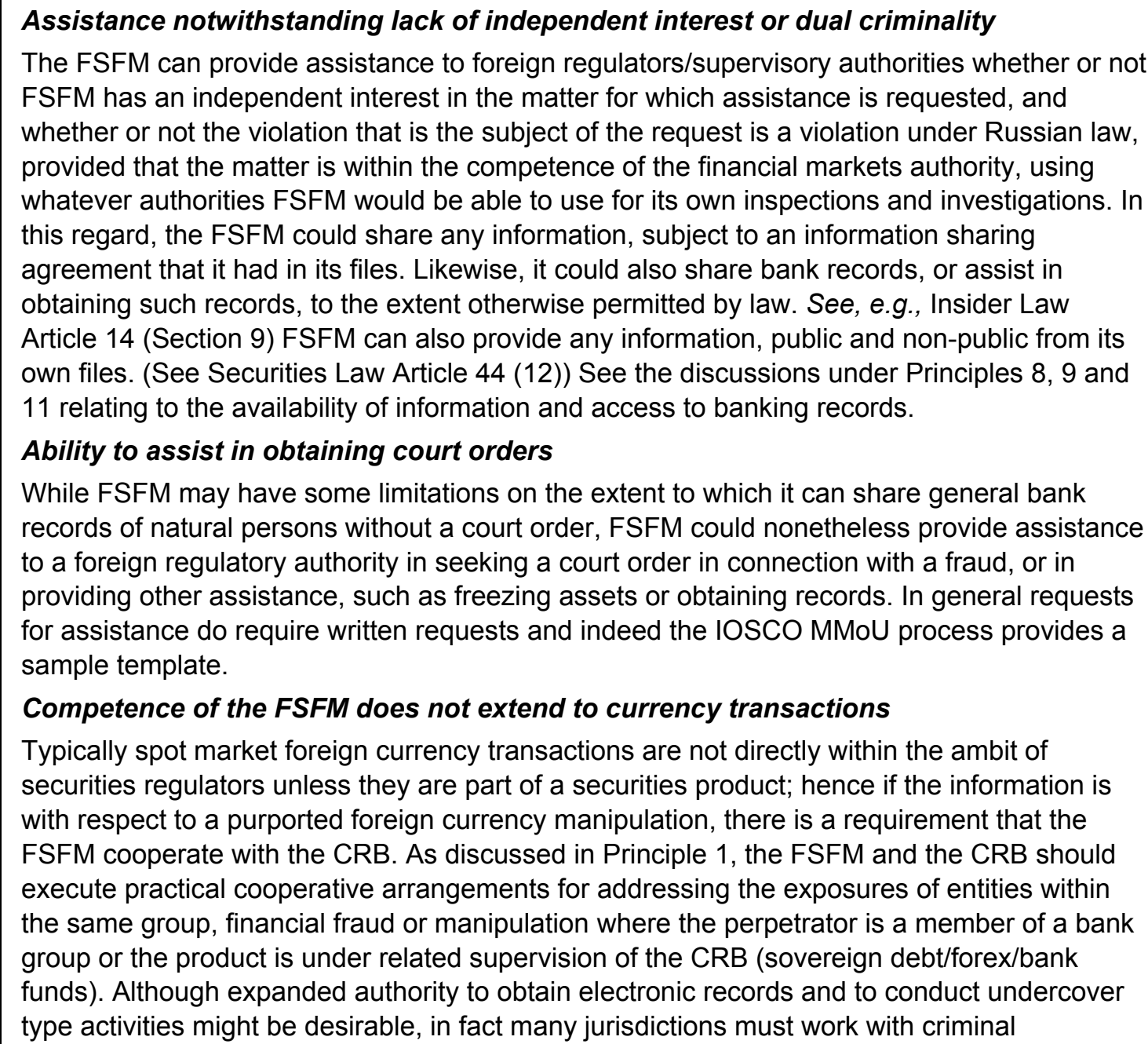 \\
\hline
\end{tabular}




\begin{tabular}{|c|c|}
\hline & $\begin{array}{l}\text { authorities in these types of investigations. } \\
\text { Confidentiality } \\
\text { As discussed, non-public information provided by a foreign regulator to the FSFM cannot be } \\
\text { onward shared without consent of the foreign regulator or a court order. (See, e.g., Insider } \\
\text { Law Article } 15 \text { (3), and Securities Law Article } 44 \text { (12) and } 44.1 \text { and the relevant language of } \\
\text { specific bi-lateral MoUs. The FSFM has the power to join an agreement with a foreign } \\
\text { authority to resist the imposition of a court order, which would be required for it to join the } \\
\text { IOSCO MMoU. (The additional processes necessary to obtain bank records for natural } \\
\text { persons are noted in Principle } 8 \text { above.) } \\
\text { Information on financial groups } \\
\text { Pending consolidated supervision requirements and planned related amendments to the } \\
\text { banking laws should facilitate obtaining general bank information related to the proper } \\
\text { supervision of financial conglomerates. Information on securities transactions through to the } \\
\text { direct client of the broker can be obtained directly from the market and domestically licensed } \\
\text { intermediaries; regulation that requires local intermediaries to obtain specific ownership } \\
\text { information within another jurisdiction is pending and the use of information sharing } \\
\text { arrangements with other regulators, in whose jurisdictions cross border transactions may be } \\
\text { initiated should also facilitate obtaining information as necessary. } \\
\text { Some examples } \\
\text { FSFM indicates that it has cooperated with the Cyprus authorities and that it has provided } \\
\text { informal assistance to the SEC. In fact, it indicates it has more frequently requested } \\
\text { information than been requested to provide the same. }\end{array}$ \\
\hline Assessment & Partly Implemented \\
\hline Comments & $\begin{array}{l}\text { FSFM should continue to improve the legislative and regulatory underpinning of its ability to } \\
\text { provide assistance to its regulatory counterparties and where there are ambiguities of } \\
\text { interpretation or perceived ambiguities. FSFM should use whatever authorities it may have to } \\
\text { eliminate these by clarification, undertaking, diplomatic note, or interpretation to the extent } \\
\text { possible. In this regard, information sharing arrangements with those jurisdictions where most } \\
\text { cross-border transactions occur and execution of the MMoU should be pursued actively. } \\
\text { Additionally, in view of the broad concern internationally with the ability to promptly address } \\
\text { global interconnections that could adversely affect one's home jurisdiction, FSFM should } \\
\text { work with all related domestic financial regulators and, as necessary, the FIU, to be sure that } \\
\text { it has considered the types of information needed to address various market disruption and } \\
\text { intermediary default scenarios and the means to go about obtaining such information. Further } \\
\text { FSFM should take steps to determine how to ensure that it will have adequate resources to } \\
\text { provide effective and timely assistance when requested (See also Principles } 1,24 \text {, and } 29 \text { ). }\end{array}$ \\
\hline \multicolumn{2}{|r|}{ Principles for Issuers } \\
\hline Principle 14. & $\begin{array}{l}\text { There should be full, accurate and timely disclosure of financial results and other information } \\
\text { that is material to investors' decisions. }\end{array}$ \\
\hline Description & $\begin{array}{l}\text { As of } 2009 \text { there were approximately } 522,968 \text { public companies in Russia, of which it is } \\
\text { estimated that about } 10,000 \text { represent offerings to more than } 500 \text { investors (which are } \\
\text { described as public offers) either through prospectus or through a government privatization, } \\
\text { for which continuous disclosure is required. In comparison a substantially smaller number of } \\
\text { companies are listed or admitted to trading on MICEX and RTS, respectively. For offerings } \\
\text { made only to certain "qualified" (a specified list, including for example professional market } \\
\text { participants, governmental entities) of investors, less disclosure is required. }\end{array}$ \\
\hline
\end{tabular}




\section{Disclosure Requirements}

The FSFM prescribes prospectus and ongoing disclosure requirements for both equity and bond offerings (and investment funds, which are discussed in Principles 17 to 20). FSFM requires both financial and non-financial reporting. The Securities Law (Articles 22 and 30) requires a prospectus, quarterly reports, and "material event" reporting. The Securities Law also contains a general requirement that any "information that would be viewed as material to the investment decisions of an investor," be disclosed (Article (30)) in the Prospectus and as a material event. The law contains a long list of "material event," disclosures, such as the change in an accountant or a chief financial officer, and disclosures on large shareholdings, including those through connected and controlling parties (which were recently enhanced and augmented by amendments that went into effect in March 2011), changes in control or ownership above a specific threshold, related party transactions, other losses, such as the loss of rights relative to the business. (See also Principle 15) Prospectus disclosure is considered stale after six months.

The Company Law requires that an annual report, balance sheet, and profit and loss statement be published in a mass media publication (Article 92). Material event disclosure must be made through designated venders on line and must be made within one day. For all companies required to have a prospectus, this information must also be posted on the company website. Quarterly reports must be filed within 45 days of the end of a calendar quarter and posted on the company's website. The annual audited report is due within 120 days from the end of the calendar year. The FSFM reports that these filings are becoming more timely, and is the process of considering further automating its review process. The reports must be in a prescribed format and are filed with FSFM electronically. Consideration is being given to moving to an automated review for certain specified matters. The issuer's Board must approve the prospectus and the Chief Executive/Manager and the accountant must sign and are responsible for the accuracy of the disclosures. See e.g., Securities Law Article 22.1, Article 30 (1).

\section{Contents of Prospectus}

All companies with registered prospectuses (which is a precondition to the public circulation of their securities) are obliged by law to comply with periodic and ad hoc (material event) disclosure requirements. Prospectus disclosure includes information on essential facts, business risks, business strategy, asset structure, general risk factors, how the issuer will use proceeds of the offering, information on the Executive Board and the board of Directors, including relationships to other persons in management or the board, direct shareholdings as a percentage of capital. Disclosure is also required as to the aggregate remuneration of the Board of Directors and the aggregate remuneration for the Executive Board. All owners of 5 percent or more shares are listed in the prospectus. Additionally an issuer must disclose the owners of substantial blocks of shares that exceed $5,10,25,30,75$, and 95 percent of all issued equities as a material event. The stock exchanges also have listing requirements for those offers that are listed (that is where the issuer applies to the exchange) as opposed to admitted to trading (that must meet other criteria) that provide additional detail. The listing rules, typically pertain to market capitalization and liquidity, and are subject to the review and approval of the FSFM.

\section{Listed Securities}

The exchanges may impose higher requirements on their members and listed companies than the FSFM. For example, the RTS imposes special governance requirements on the top two tiers of listings, which include for example the requirement of independent directors and a compensation committee among others. MICEX also has added requirements which are merit based for top tier listings (See also Principle 15). 


\begin{tabular}{|c|c|}
\hline & $\begin{array}{l}\text { Advertizing } \\
\text { The Investor Protection Law bans the advertizing of offerings of issuers that is inconsistent } \\
\text { with the disclosure requirements or without the filing of a prospectus. } \\
\text { Standard of Review } \\
\text { The FSFM reviews prospectuses and other filings for completeness and consistency. It has } \\
\text { the authority to ask for clarifications and revisions. Corporate bond offerings have additional } \\
\text { requirements, see e.g., Securities Law Article } 27.5 \text { et seq). Such offerings cannot be made } \\
\text { until after three years of operations of the company, unless (i) a third person provides } \\
\text { collateral, (ii) the bonds are only issued to qualified entities, (iii) other securities of the } \\
\text { company are listed at a stock exchange, and (iv) the issuer or the bonds is rated at a } \\
\text { specified level by an authorized rating agency. } \\
\text { Off-shore investment products that offer Russian units of participation are also subject to } \\
\text { particularized disclosure requirements. } \\
\text { Derogations } \\
\text { There do not appear to be any derogations from these requirements. } \\
\text { Cross-border issues } \\
\text { The Prospectus, and financial disclosures, must be reported based on the highest level of } \\
\text { disclosure that the issuer is required to give if it is either listing outside of Russia, or if it is, for } \\
\text { example, preparing financial reports both using Russian Accounting Standards and internally } \\
\text { using IFRS. In other words if a foreign regulatory authority would require specific disclosures } \\
\text { that are not required in Russia, those disclosures would also have to be made in its } \\
\text { prospectus, financial reports and material event reporting. } \\
\text { There also are regulations with respect to offer of Russian depository receipts that have } \\
\text { parallel disclosure requirements. See also Federal Law } 74-F Z \text { amending the Securities Law } \\
\text { and the Investor Protection Law, which specify the provisions relative to the offer of foreign } \\
\text { issuers within Russia. } \\
\text { Enforcement } \\
\text { The FSFM has the power to take action against issuers for failure to follow its requirements } \\
\text { and reports that many of the actions taken in the regions relate to such matters, including the } \\
\text { notices given with respect to annual meetings among other things. }\end{array}$ \\
\hline Assessment & Partly Implemented \\
\hline Comments & $\begin{array}{l}\text { The FSFM should keep the timeliness of disclosures under scrutiny and take enforcement } \\
\text { action where warranted to 'encourage' compliance. FSFM should also move toward } \\
\text { international best practice among the G- } 20 \text { countries for timeliness of filing of annual audited } \\
\text { reports and for sufficiency of shareholder notices relative to annual meetings and voting } \\
\text { decisions. The use of automated systems to help with this is recommended. } \\
\text { The enhancement of connected ownership and control reporting is welcome, although } \\
\text { experience will have to be obtained with how well it will work within the culture of this } \\
\text { marketplace. The exchanges do have the capacity to ask for enhanced disclosures about } \\
\text { underlying customers, and the pressure to make underlying ownership more transparent is } \\
\text { increasing, especially for companies that wish to list outside of Russia. Nonetheless, active } \\
\text { review procedures will be necessary to test the efficacy of the new connected disclosure } \\
\text { requirements. Significant study has been undertaken on how to improve reporting } \\
\text { requirements so FSFM should be able to take stronger enforcement steps where violations } \\
\text { are observed. Further steps might become necessary if the newly designed control reporting } \\
\text { requirements do not permit adequate identification of controlling interests. In some }\end{array}$ \\
\hline
\end{tabular}




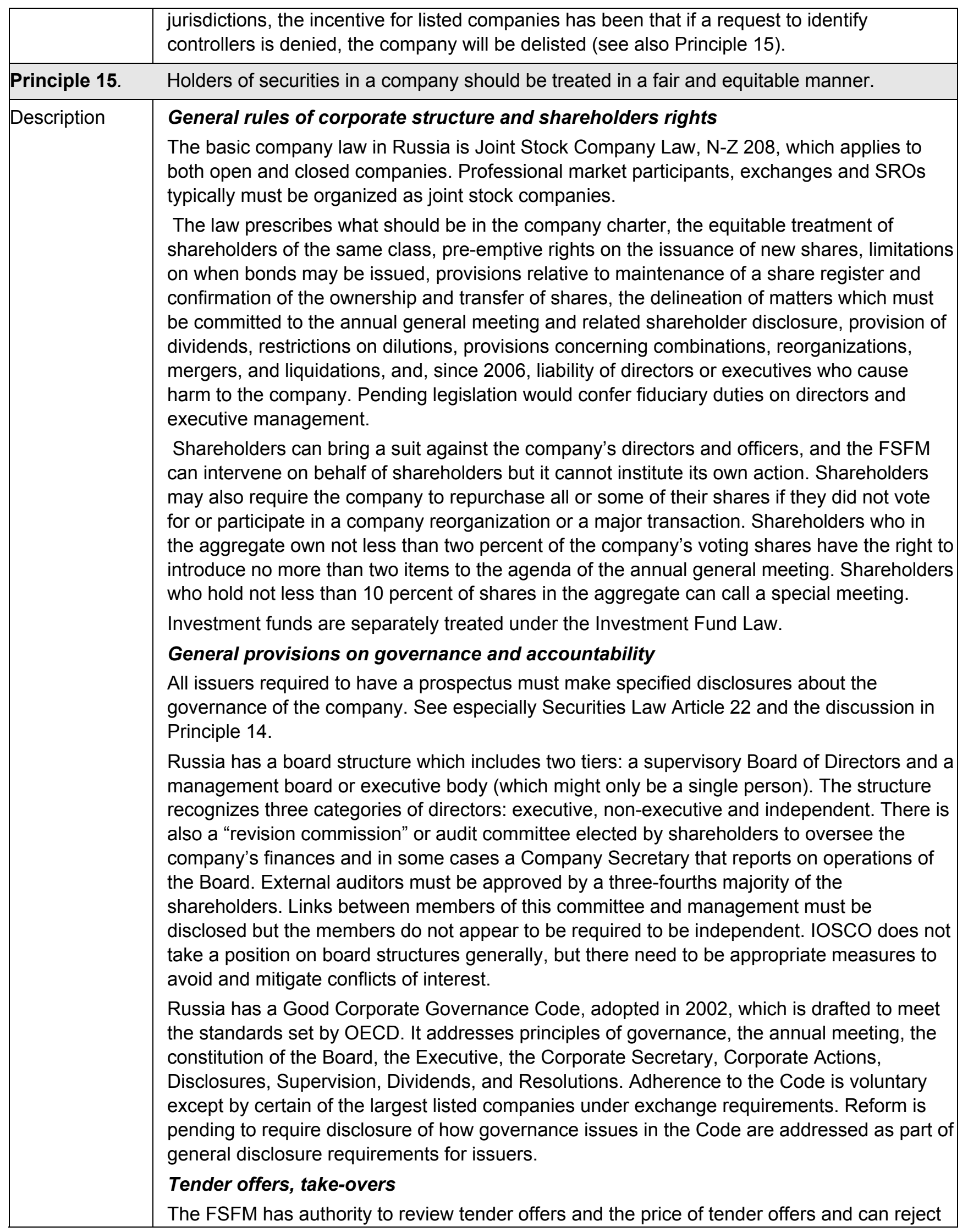




\begin{tabular}{|c|c|}
\hline & 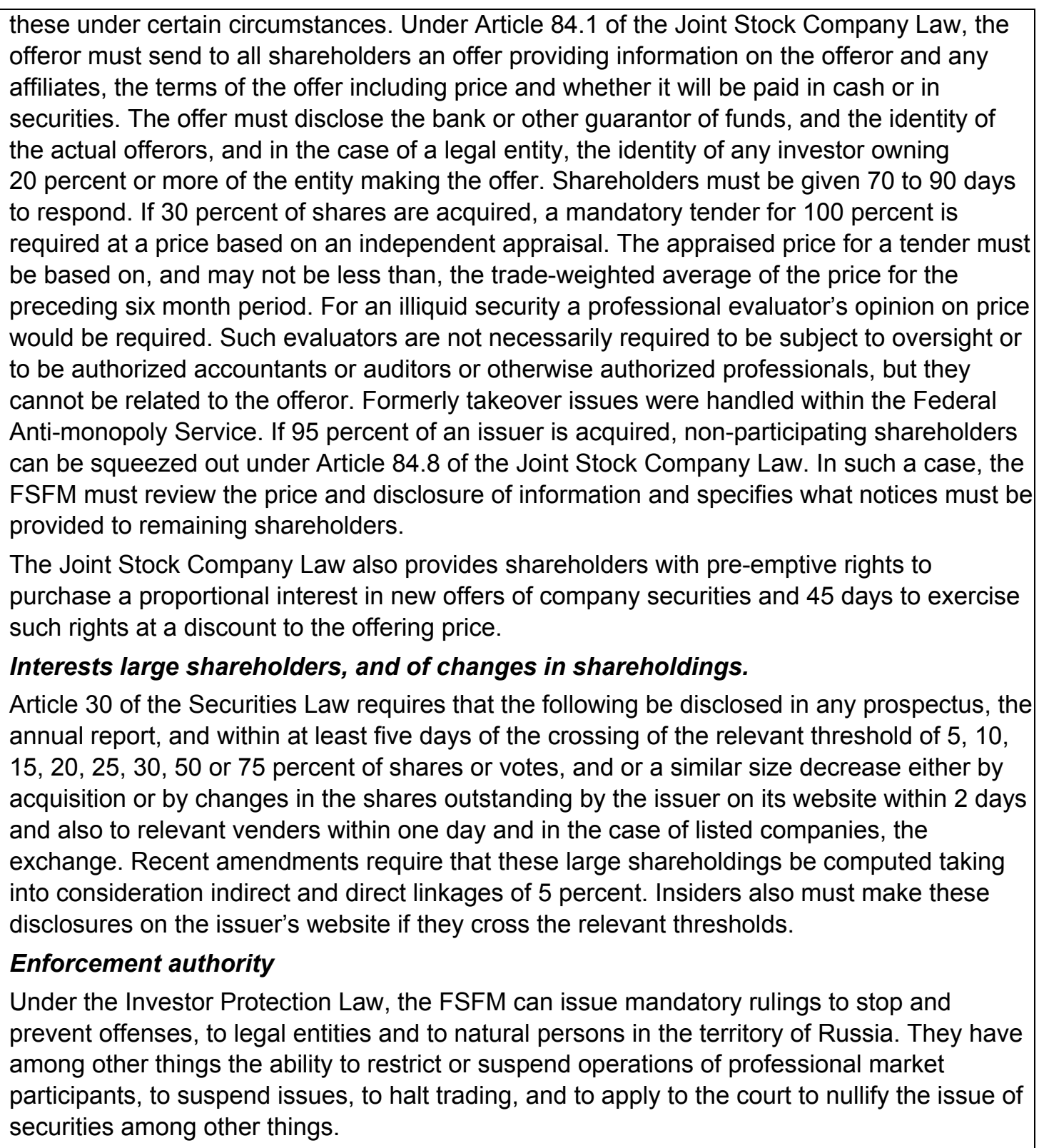 \\
\hline Assessment & Partly Implemented \\
\hline Cor & $\begin{array}{l}\text { Contemplated improvements in the share registry arrangements, may aid the ability to } \\
\text { determine underlying ownership. The legal issue as to who is the "owner" of the shares held } \\
\text { in street name or through a depository receipt could be further clarified. This would enhance } \\
\text { the capacity of non-domestic firms to transact directly in the Russian market. } \\
\text { The addition of augmented owner and controller reporting that includes indirect holdings of } \\
5 \text { percent is welcome. FSFM should keep abreast of developments relative to derivatives } \\
\text { regulation related to best practices relative to who is the effective owner of the voting interest } \\
\text { in equity securities. In that shares may be held in nominee name, how this will operate should } \\
\text { be clarified by interpretation. } \\
\text { The changes with respect to tender offers, and tender offer pricing since the last review take } \\
\text { into account the issue of illiquid shares. How the pricing provisions operate in practice should } \\
\text { be kept under continuing review. }\end{array}$ \\
\hline
\end{tabular}




\begin{tabular}{|c|c|}
\hline & $\begin{array}{l}\text { The FSFM should make disclosure of whether an issuer complies with the code of corporate } \\
\text { governance or an explanation a matter of disclosure for all public companies on an annual } \\
\text { basis. } \\
\text { Further the disclosure of all shareholdings of officers and directors in an issuer should be } \\
\text { required disclosures. } \\
\text { The new IOSCO Principles apply additional requirements to the use of professional } \\
\text { evaluators and FSFM should take steps to prepare for the implementation of these } \\
\text { requirements. }\end{array}$ \\
\hline Principle 16. & Accounting and auditing standards should be of a high and internationally acceptable quality. \\
\hline Description & 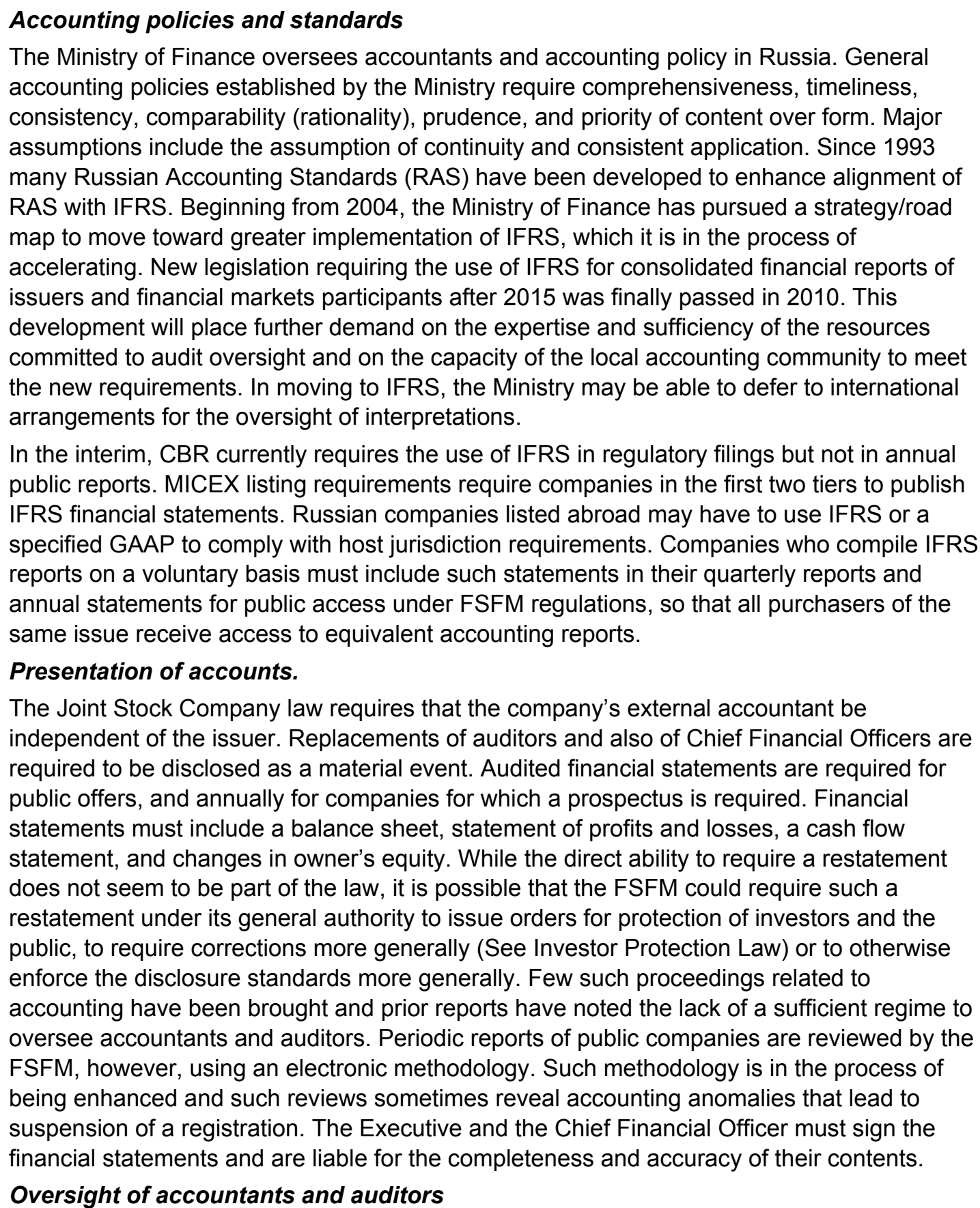 \\
\hline
\end{tabular}




\begin{tabular}{|c|c|}
\hline & $\begin{array}{l}\text { The Ministry of Finance is not only responsible for accounting policies and standards, it also } \\
\text { is responsible for the licensing and supervision of auditors and audit firms, of which there are } \\
\text { approximately } 37,000 \text { and } 15,000 \text { respectively. While the auditors must belong to } \\
\text { professional organizations (SROs), the oversight by either the Ministry or the SROs remains } \\
\text { limited, and the use of multiple SROs may raise issues about consistent oversight of the } \\
\text { standards that do exist that is being combated in other arenas by aggregating interpretations } \\
\text { and information on disciplinary actions (See European Securities Supervisory Markets } \\
\text { Association and IOSCO projects). } \\
\text { Enhancement and oversight of auditing standards has not progressed to the extent of } \\
\text { accounting standards. }\end{array}$ \\
\hline Assessment & Partly Implemented \\
\hline Comments & $\begin{array}{l}\text { Mechanisms should be in place for oversight of the accounting and auditing profession that } \\
\text { are sufficient to be an effective means of discipline on the profession. Mechanisms should be } \\
\text { also explored to determine how best to obtain the accounting expertise that will be necessary } \\
\text { to phase in the changes as IFRS standards are more broadly required. Some thought must } \\
\text { be given to how to treat accounting oversight relative to purely domestic small and medium } \\
\text { size enterprises. } \\
\text { The requirement to be a member of a professional association, subject to Ministry of Finance } \\
\text { oversight is useful especially if some means of assuring consistent interpretations is } \\
\text { developed, so that there are not competing standards. Additionally, efforts should be } \\
\text { undertaken as part of ongoing cooperation between the financial sector supervisors and the } \\
\text { Ministry of Finance to ensure that not only is adequate oversight conducted, but also that } \\
\text { emerging lessons learned from the marketplace are transmitted to the accounting profession } \\
\text { and that the supervisors have adequate input in the evolution of standards. FSFM should } \\
\text { have gained some expertise relevant to the oversight of accountants work through its review } \\
\text { of financial reporting more generally. The Ministry of Finance could seek to draw on that } \\
\text { expertise as part of ongoing cooperative efforts among the financial sector authorities. The } \\
\text { Ministry of Finance and the FSFM may also consider making more active use of the SRO } \\
\text { process or other means to involve local accountants in a peer review process. }\end{array}$ \\
\hline \multicolumn{2}{|r|}{ Principles for Collective Investment Schemes } \\
\hline Principle 17. & $\begin{array}{l}\text { The regulatory system should set standards for the eligibility and the regulation of those who } \\
\text { wish to market or operate a collective investment scheme. }\end{array}$ \\
\hline Description & $\begin{array}{l}\text { Licensing requirement (initial and ongoing) } \\
\text { The Investment Law requires the licensing of Management Companies and Special } \\
\text { Custodians of Investment Funds. The Law also requires that such funds can only be } \\
\text { sold/marketed by the Management Company, which is licensed, or by its agent, which must } \\
\text { be a licensed broker. The procedures for the licensing process are laid out in the regulations. } \\
\text { The law applies a fit and proper test that is expanded by regulation. Under the law, specified } \\
\text { personnel (e.g., the internal controller) must obtain a qualifications certificate. Management } \\
\text { and company owners of more than } 5 \text { percent must be free of disqualifying conditions, such } \\
\text { as a regulatory violation within three years, and must pass a background check for their } \\
\text { criminal record with the Ministry of Internal Affairs. The law specifies other criteria for } \\
\text { licensing, which include a due diligence review based on filings of internal control rules and } \\
\text { competency qualifications, Management Companies and Custodians must also meet "own } \\
\text { funds" requirements. In the case of special custodians these are due to be raised to Rub } 80 \\
\text { million in July. } \\
\text { There are both monetary penalties and license revocation and receivership proceedings that }\end{array}$ \\
\hline
\end{tabular}


can be used as a means to address violations of the applicable law that apply to Investment Funds. FSFM has recently adopted an Order under the Securities Law, which permits FSFM while considering the granting of a license to conduct interviews and/or on-site inspections as a further means of determining the operational capacity of applicants.

These requirements however do not necessarily apply to bank managed investment funds (See Principle 1).

\section{Reporting requirements}

Required reports to the FSFM are submitted electronically under electronic signature. The FSFM reviews these reports which include information on certain material changes in the constitution of the Management Company managers or by-laws, and price reporting. The inspection department indicates that they conduct on-site inspections of fund managers on a cycle, which permits observation of the operational capacity of the management companies in practice.

\section{Related party transactions}

Related party transactions are restricted. For example, the special custodian used must be independent; that is, it cannot be affiliated or under common control with the fund or management company, nor on the management board of a joint stock company fund. And other restrictions are intended to address the independence of appraisers and auditors. Just as there are a number of prohibitions on related party transactions, certain specific exceptions exist (Article 40 of the Investment Fund Law), which include transactions on a regulated market, or transactions that are addressed by disclosure and other protections such as inspections. Funds can purchase interests in other funds operated by the same operator for example. Disclosure of the exceptions is important. In the future, more attention can be expected to be applied to the regulatory processes and requirements related to the avoidance of conflicts and the full disclosure of such exceptions. FSFM should keep abreast of IOSCO advice and reports. The requirement for the use of independent auditors and appraisers should also be a protection if properly monitored for compliance.

\section{Use of SROs}

The Law also provides for the applicable SRO to adopt rules related to a code of ethics, own funds or capital that may be higher than those of the FSFM, advertizing, rights of clients, verifications of valuations etc, inspections, and monitoring processes.

The FSFM has full authority to demand information relative to investment funds and can place managers and/or funds into a provisional administration or receivership, though these powers have not been comprehensively tested in practice.

The largest by number and value of assets currently are closed end real estate investment fund trusts. These funds were typically captive funds that were a popular way to fund development of property as a commercial enterprise among developers. These investments are now less attractive because their favorable tax treatment has been withdrawn.

\section{Customer Protections}

While there are rules for fair disclosure, related to fees and expenses, and against related party transactions, and certain specified conflicts, there do not appear to be rules on best execution. The FSFM has broad authority under the Investor Protection Law to provide further protections to retail investors based on experience.

\section{Delegation.}

Delegations are not permitted.

\section{Monitoring}

There is a program for monitoring each of the components of a CIS. The funds themselves 


\begin{tabular}{|c|c|}
\hline & $\begin{array}{l}\text { must provide information to the FSFM and also to all investors in certain circumstances on } \\
\text { specified material changes. These changes cannot be immediately made, to permit investors } \\
\text { an opportunity to withdraw. The Management Company and the Custodian are each subject } \\
\text { to inspections. The FSFM indicates that its inspection cycle for Management Companies is a } \\
\text { three year cycle. }\end{array}$ \\
\hline Assessment & Partly Implemented \\
\hline Comments & $\begin{array}{l}\text { The transfer of assets among funds or the purchase of one fund by another by the same } \\
\text { Manager (as opposed to the unit holder who is a participant in a family of funds) is permitted. } \\
\text { These types of transactions should be monitored. To assure that there are not abuses. The } \\
\text { new IOSCO Principles will require comprehensive processes at the regulator to avoid or } \\
\text { mitigate conflicts of interests. }\end{array}$ \\
\hline Principle 18. & $\begin{array}{l}\text { The regulatory system should provide for rules governing the legal form and structure of } \\
\text { collective investment schemes and the segregation and protection of client assets. }\end{array}$ \\
\hline Description & 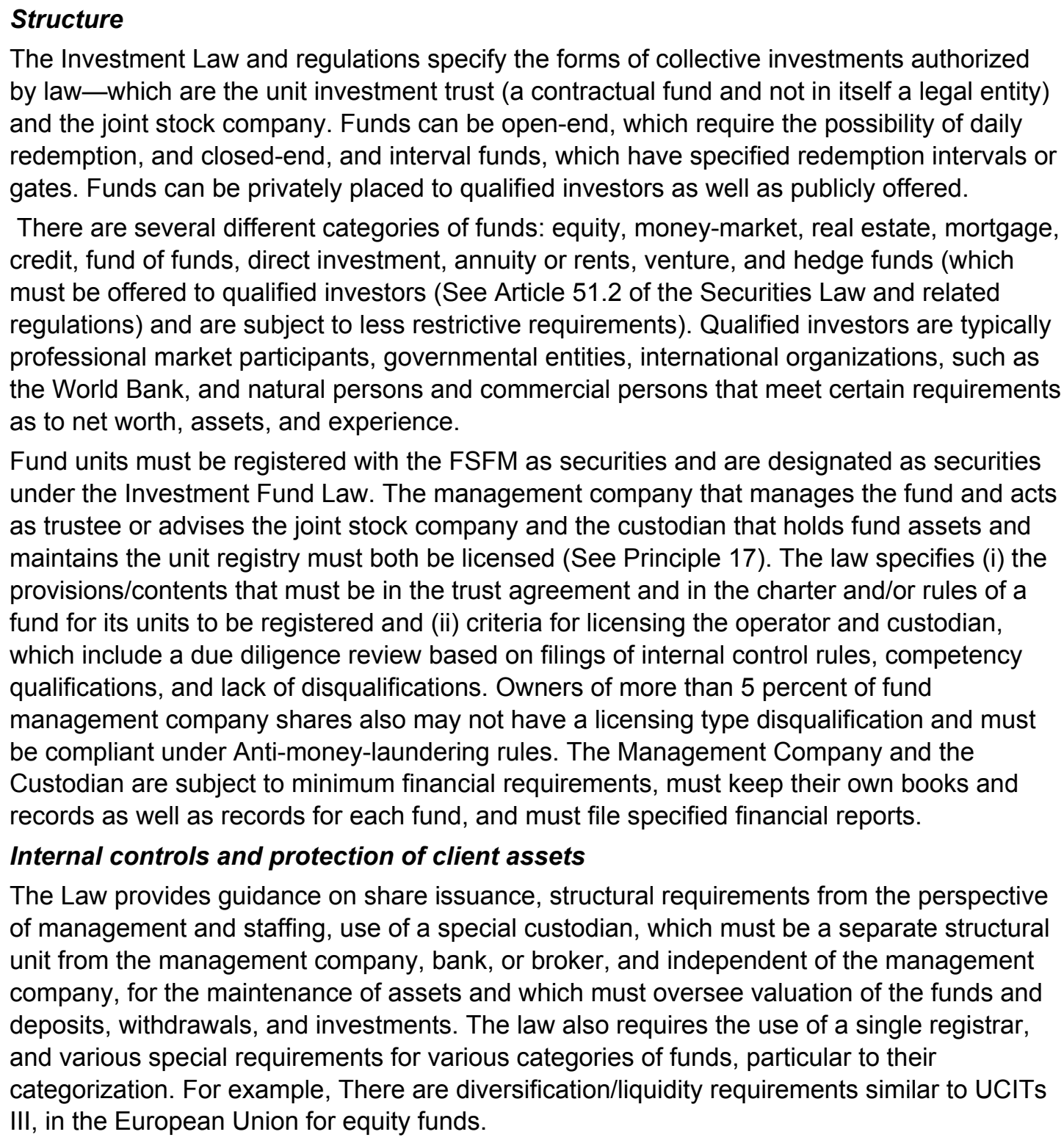 \\
\hline
\end{tabular}




\begin{tabular}{|c|c|}
\hline & $\begin{array}{l}\text { Funds that are joint stock companies must file quarterly periodic financial reports and be } \\
\text { audited annually. Unit investment funds' Management Companies must publish quarterly } \\
\text { balance sheets of fund assets and report on the changes in assets as well as other data. The } \\
\text { Management Company must also publish its own quarterly financial reports and be audited } \\
\text { annually. } \\
\text { Separate treatment of assets } \\
\text { The Management Company and the Special Custodian must separately account for and treat } \\
\text { the portfolio assets and any funds of the collective investment as funds of the unit holders or } \\
\text { participants. By law, assets of the fund are not considered assets of the Trustee, } \\
\text { Management Company or Custodian for purposes of bankruptcy. The external auditor of fund } \\
\text { interests is required to confirm proper observance of custody arrangements for investment } \\
\text { funds and the proper calculation of net asset value and observance of investment structural } \\
\text { policies. } \\
\text { If requests for redemption of } 75 \text { percent of the fund are made, the fund must liquidate. } \\
\text { Current provisions are in place for a temporary receiver or provisional administrator to } \\
\text { address the protection of customer assets and the management of any liquidation. } \\
\text { The Law grants authority to the FSFM to expand on these requirements through the issuance } \\
\text { of secondary legislation, that is, regulations, in several areas explicitly set forth in the } \\
\text { umbrella law. } \\
\text { Disclosure of changes in investment policies, constituent documents, and fees must be made } \\
\text { to the regulator as well as investors (see discussion in Principle 19). }\end{array}$ \\
\hline Assessment & Implemented \\
\hline Comments & $\begin{array}{l}\text { Enforcement of the legal forms of funds should be kept under scrutiny. If new formats such } \\
\text { as ETFs are created, the law should be adapted to assure proper oversight and recognition. } \\
\text { The new alignment may commit some of this discretion to the Ministry of Finance in } \\
\text { cooperation with the FSFM in this area. As stated in the preface to this assessment, how } \\
\text { these powers are exercised going forward could affect compliance. }\end{array}$ \\
\hline Principle 19. & $\begin{array}{l}\text { Regulation should require disclosure, as set forth under the principles for issuers, which is } \\
\text { necessary to evaluate the suitability of a collective investment scheme for a particular } \\
\text { investor and the value of the investor's interest in the scheme. }\end{array}$ \\
\hline Description & $\begin{array}{l}\text { Constitution (By-Laws) or Trust Agreement and Trust Policies or Rules } \\
\text { Article } 11 \text { of the Investment Fund Law sets outs what must be in a Trust Agreement or Deed } \\
\text { for a unit investment trust and rules set forth a specific template. Article } 6 \text { has similar } \\
\text { requirements for Joint Stock Companies. Article } 17 \text { contains the rules that must be disclosed, } \\
\text { these include: } \\
\text { - } \quad \text { the type of fund, } \\
\text { - } \quad \text { the declaration of trust or deed, } \\
\text { - } \quad \text { the process of subscription, } \\
\text { - } \quad \text { the name of the management company, custodian, registrar and auditor and related } \\
\text { information, } \\
\text { - } \quad \text { the rights of participants, } \\
\text { - the duration of the trust, } \\
\text { - the procedure to include property, and investment policies } \\
\text { the procedures for valuation, }\end{array}$ \\
\hline
\end{tabular}




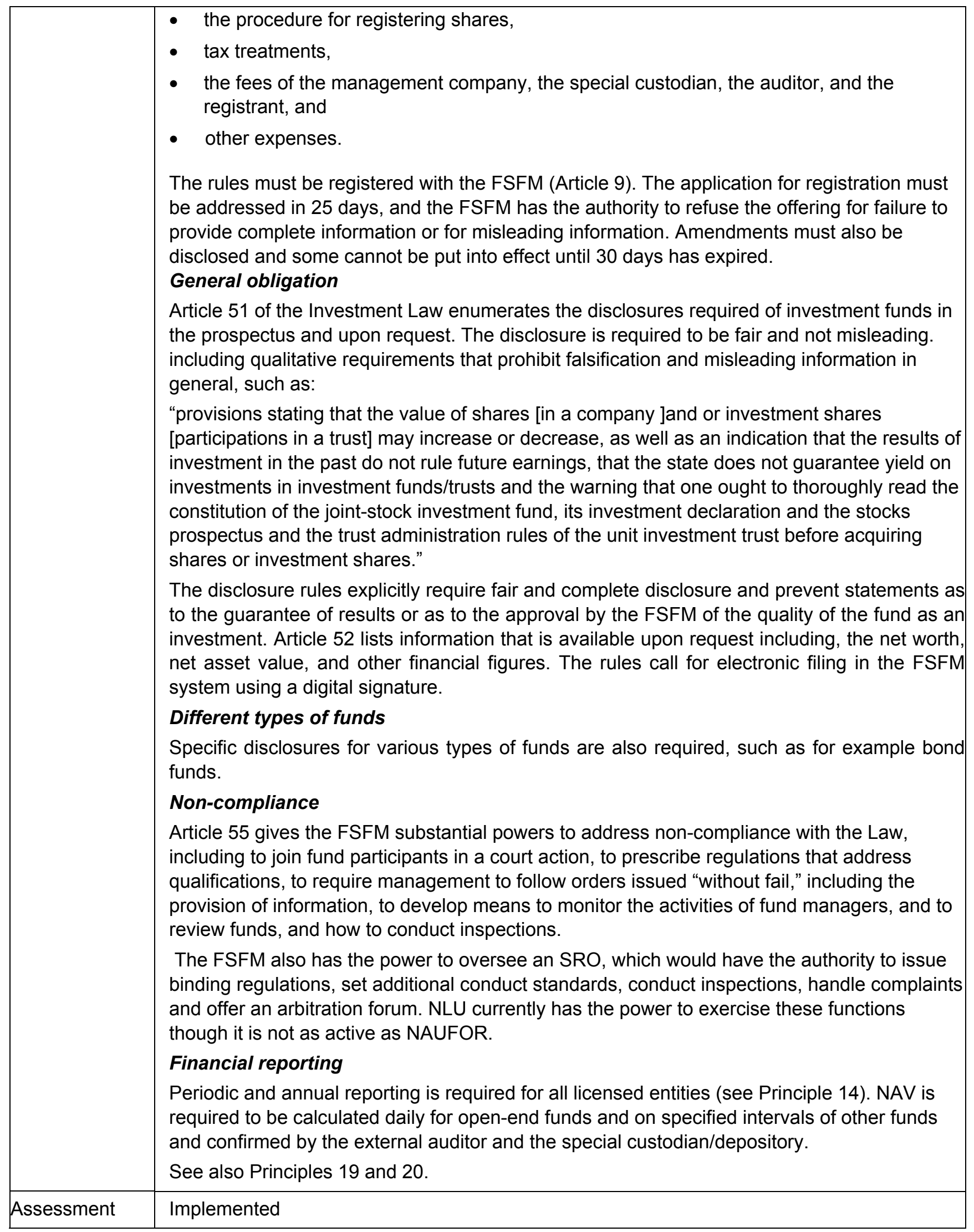




\begin{tabular}{|c|c|}
\hline Comments & $\begin{array}{l}\text { It is important that disclosure is readily understandable in plain language. This is often } \\
\text { addressed using a by short and long form risk disclosures. } \\
\text { Generally it is important that investors understand that investment funds are not the } \\
\text { equivalent of bank deposits and are not insured. } \\
\text { Most of the real estate funds are captive funds. Therefore the issues that arise with respect } \\
\text { to such funds may be more about how those funds are used by their creators and other } \\
\text { parties for accounting and not on customer protection for the funds participants. }\end{array}$ \\
\hline Principle 20. & $\begin{array}{l}\text { Regulation should ensure that there is a proper and disclosed basis for asset valuation and } \\
\text { the pricing and the redemption of units in a collective investment scheme. }\end{array}$ \\
\hline Description & 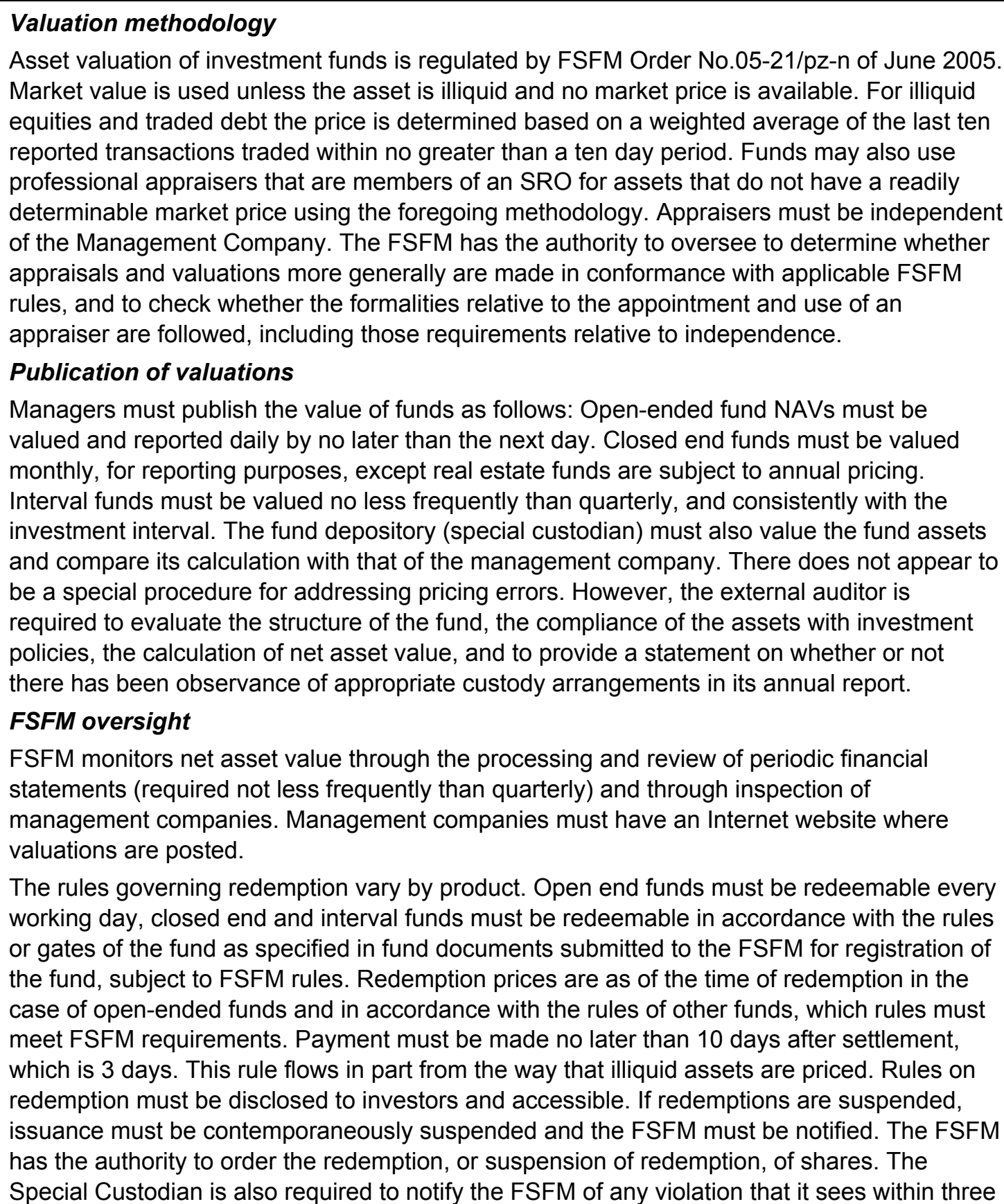 \\
\hline
\end{tabular}




\begin{tabular}{|c|c|}
\hline & $\begin{array}{l}\text { working days. } \\
\text { Practice } \\
\text { FSFM conducts inspections on a cycle. It also conducted some inspections relative to the } \\
\text { market timing issues experienced by other markets. } \\
\text { The general rules for issuers apply to financial reporting by funds, but the auditor must make } \\
\text { additional confirmations as to the existence of assets at the custodian (see also Principle 19). }\end{array}$ \\
\hline Assessment & Broadly implemented \\
\hline Comments & $\begin{array}{l}\text { Prices are based on actual transactions as opposed to bids, and a weighted average is used. } \\
\text { If no market price is available, an appraisal by an independent appraiser is required. There } \\
\text { appears to be a standard of general fairness. The FSFM must maintain an active program to } \\
\text { review prices, appraisals, and the independence of appraisers, in light of the low level of } \\
\text { liquidity in many products to determine compliance with regulatory requirements. As many of } \\
\text { the equities traded in Russia are illiquid, the FSFM should be alert to test valuations that are } \\
\text { used for redemptions from time to time and as part of the routine inspection process. } \\
\text { The FSFM should also monitor the repayment of redemptions which should be accelerated to } \\
\text { the fullest extent possible. The pecuniary payment for redemptions should be required to be } \\
\text { made as promptly as possible after settlement but no later than a specified time frame. } \\
\text { There should be a procedure for handling pricing discrepancies and errors. }\end{array}$ \\
\hline \multicolumn{2}{|r|}{ Principles for Market Intermediaries } \\
\hline Principle 21. & Regulation should provide for minimum entry standards for market intermediaries. \\
\hline Description & $\begin{array}{l}\text { License requirement } \\
\text { Licenses are required for all professional market participants engaged in securities } \\
\text { transactions, including for the securities operations of banks. These participants include: } \\
\text { brokers, dealers, investment management companies, investment company special } \\
\text { custodians, depositories (both settlement and custodial), and registrars. There is no separate } \\
\text { license category for investment advisers. Advice for a fee on securities must be given } \\
\text { through a licensed broker, and entities which carry customer funds for investment purposes } \\
\text { must all be licensed as brokers. The FSFM has the authority to refuse licensing subject only } \\
\text { to judicial review. } \\
\text { License process. } \\
\text { A fit and proper standard is applied. This includes absence of certain disqualifications, } \\
\text { compliance with competency requirements (that may include testing), and capital. } \\
\text { Professional market participants must be legal entities. } \\
\text { Capital as related to licensing } \\
\text { There is an "own funds," or capital requirement for each category of intermediary, that has } \\
\text { been increased over the years (see Principle } 22 \text { below)-except that banks can meet bank } \\
\text { capital requirements. The minimum capital requirement for brokers was due to be increased } \\
\text { substantially in July } 2011 \text { to Rub } 50 \text { million but that enhancement was postponed by draft } \\
\text { order of the FSFM in May. Under the new regulatory structure for FSFM, the development of } \\
\text { capital standards has been committed to the Ministry of Finance, in coordination with the } \\
\text { FSFM. } \\
\text { Bank securities operations, though licensed by the FSFM, may be conducted under the } \\
\text { capital rules applicable to the bank, subject to CBR supervisory review. In this regard, it } \\
\text { appears that the operation of securities services generally, and not just special custodial } \\
\text { services, might in the future have to be conducted in a separate structural entity that is }\end{array}$ \\
\hline
\end{tabular}




\begin{tabular}{|c|c|}
\hline & 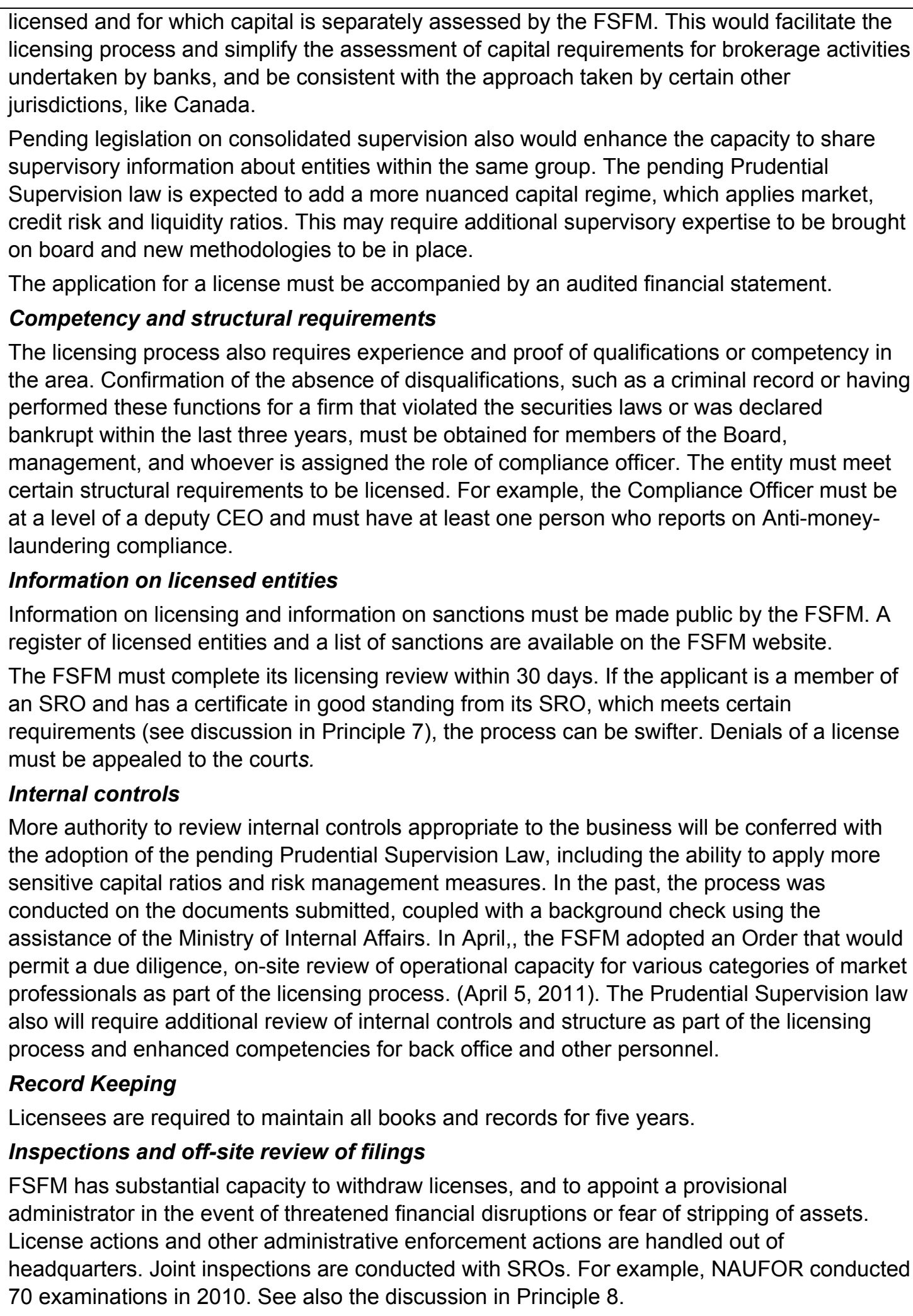 \\
\hline Assessment & Broadly Implemented \\
\hline Comı & $\begin{array}{l}\text { Some experience is necessary with the adoption of a review of operational controls as part of } \\
\text { the licensing process before a fully implemented rating could be obtained. It will also be }\end{array}$ \\
\hline
\end{tabular}




\begin{tabular}{|c|c|}
\hline & $\begin{array}{l}\text { necessary for FSFM to have sufficient expertise and staff to undertake appropriate due } \\
\text { diligence and to apply more nuanced capital requirements as required. See Principle } 22 \text {. } \\
\text { Further how the various powers will be realigned and operated in practice could potentially } \\
\text { affect this rating. }\end{array}$ \\
\hline Principle 22. & $\begin{array}{l}\text { There should be initial and ongoing capital and other prudential requirements for market } \\
\text { intermediaries that reflect the risks that the intermediaries undertake. }\end{array}$ \\
\hline Description & 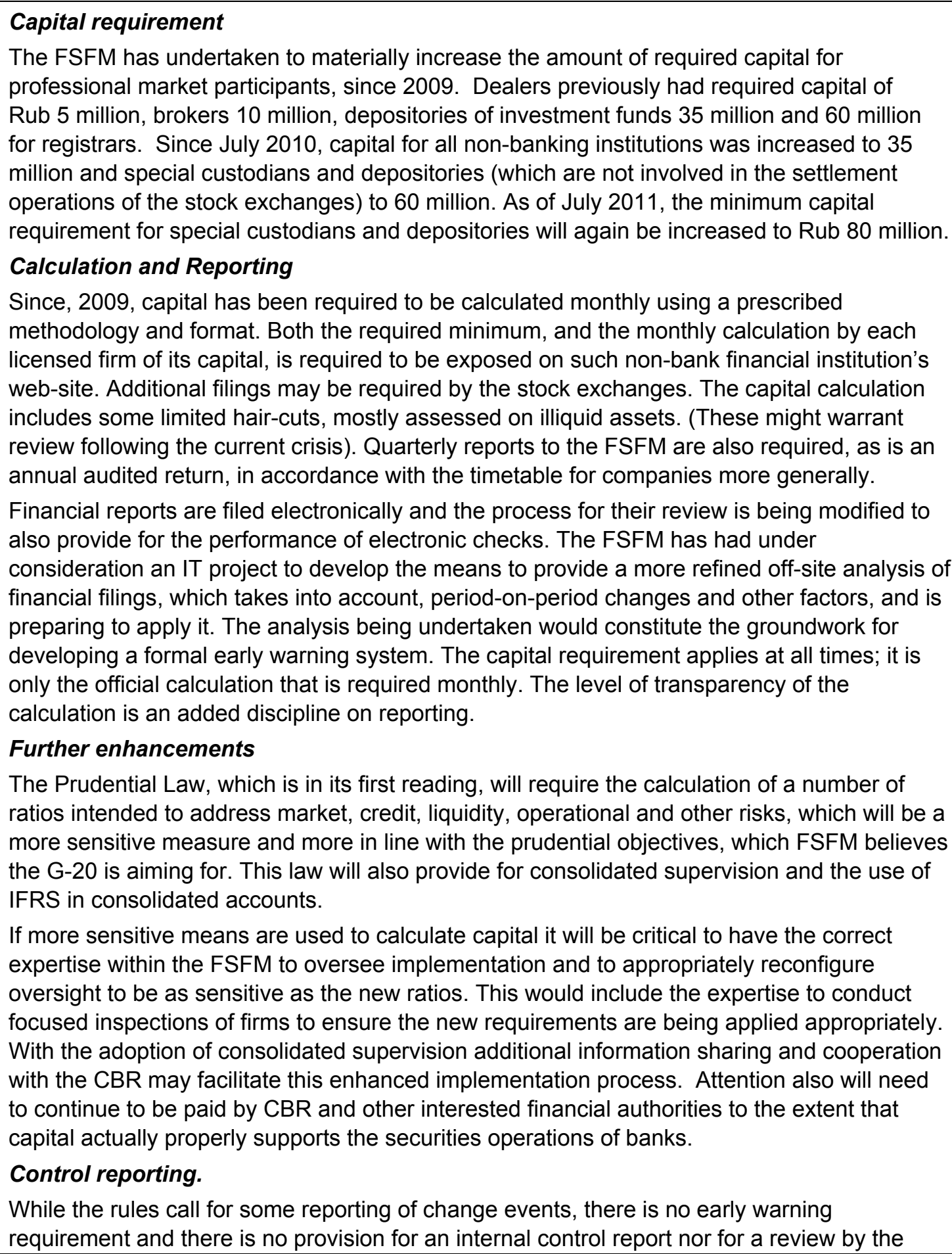 \\
\hline
\end{tabular}




\begin{tabular}{|c|c|}
\hline & $\begin{array}{l}\text { external auditor of the observance of the proper treatment of customer funds by those } \\
\text { professional market participants other than management companies and special custodians. } \\
\text { The authorized exchanges have some added requirements related to financial integrity. See } \\
\text { also the discussion under Principle } 24 \text { with respect to the pending legislation on creating a } \\
\text { compensation fund for retail investors. }\end{array}$ \\
\hline Assessment & Partly Implemented \\
\hline Comments & $\begin{array}{l}\text { Many changes are en train with respect to capital requirements. Pending increases were } \\
\text { postponed in May and the development of new rules was removed to the Ministry of Finance } \\
\text { coupled with input from the FSFM. Planned changes to enhance the review by FSFM of } \\
\text { quarterly financial reports filed by professional market participants, coupled with development } \\
\text { of a regime for more sensitive review and automated checks of the monthly calculations (to } \\
\text { produce exception reports) would enhance the oversight of capital. An early warning system } \\
\text { also should be implemented, which includes a provision related to deterioration in controls } \\
\text { and is sensitive to the types of risks and exposures undertaken by each authorized } \\
\text { professional market participant. } \\
\text { Proposed changes to the overall requirement if properly implemented and supervised should } \\
\text { help to increase the sensitivity of capital to risk. The institution of initial due diligence } \\
\text { processes (See Principle } 21 \text { ) to consider the operational capacity of firms together with } \\
\text { focused inspections of how the controls are working in practice would materially improve the } \\
\text { ability of the FSFM to come into further compliance. }\end{array}$ \\
\hline Principle 23. & $\begin{array}{l}\text { Market intermediaries should be required to comply with standards for internal organization } \\
\text { and operational conduct that aim to protect the interests of clients, ensure proper } \\
\text { management of risk, and under which management of the intermediary accepts primary } \\
\text { responsibility for these matters. }\end{array}$ \\
\hline Description & $\begin{array}{l}\text { Supervisory ,compliance controls requirements } \\
\text { The Securities Law and FSFM regulations establish broad requirements on internal } \\
\text { operations and duties owed to customers. In essence, professional market participants have } \\
\text { a duty to execute orders in good faith and to act in the best interests of customers. This } \\
\text { establishes a principle of ethical conduct to customers. This principle includes the } \\
\text { responsibility to execute transactions promptly, to disclose terms of transactions, to notify } \\
\text { clients of conflicts and to execute customer orders before firm transactions. Separate } \\
\text { requirements have been imposed to provide for the segregation of funds at a specially } \\
\text { designated account. Customer securities must also be held separately from those of the } \\
\text { broker. } \\
\text { There are also rules on the provision of information to customers and the protection of } \\
\text { information received from customers. Article } 4 \text { of the new Insider Law also defines personnel } \\
\text { of markets, clearing organizations, professional market participants, and other persons } \\
\text { executing deals with securities, currencies and financial instruments on behalf of clients who } \\
\text { receive information from such clients as insiders who cannot abuse such information., The } \\
\text { details of a best execution or trade first rule, however, do not appear to be spelled out in } \\
\text { regulations. } \\
\text { Structural requirements } \\
\text { As discussed with respect to licensing, firms are required to have a compliance officer, and a } \\
\text { person accountable for anti-money laundering compliance, with the attendant know your } \\
\text { customer provisions (or customer identity provisions) this entails. See also Principle } 21 . \\
\text { Conduct of business } \\
\text { The Investor Protection Law also contains some very important additional provisions: it }\end{array}$ \\
\hline
\end{tabular}




\begin{tabular}{|c|c|}
\hline & 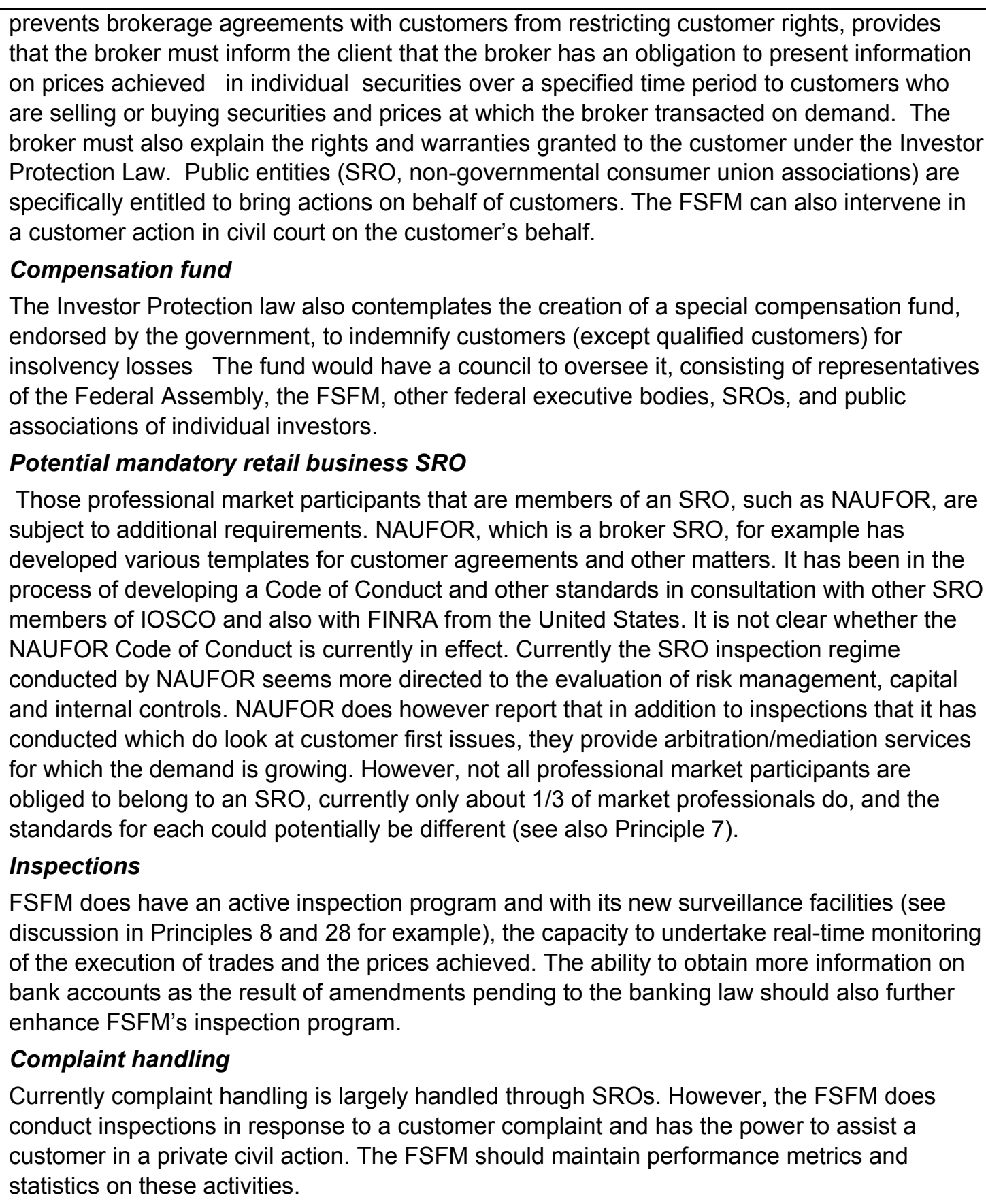 \\
\hline Assessment & Partly Implemented \\
\hline Cor & $\begin{array}{l}\text { The FSFM has just obtained expanded resources and technology to review trading activity } \\
\text { for market and customer abuses, which when fully implemented should permit the FSFM to } \\
\text { achieve a higher level of compliance. } \\
\text { The adoption of pending Prudential Supervision and Banking Law amendments should be } \\
\text { expedited. The FSFM should adapt its inspection programs to spot check for segregation and } \\
\text { other business conduct compliance, taking account of off-site financial reports. Upon } \\
\text { passage of the pending legislation, FSFM should act promptly to implement the provisions to } \\
\text { expand its supervisory protections. }\end{array}$ \\
\hline
\end{tabular}




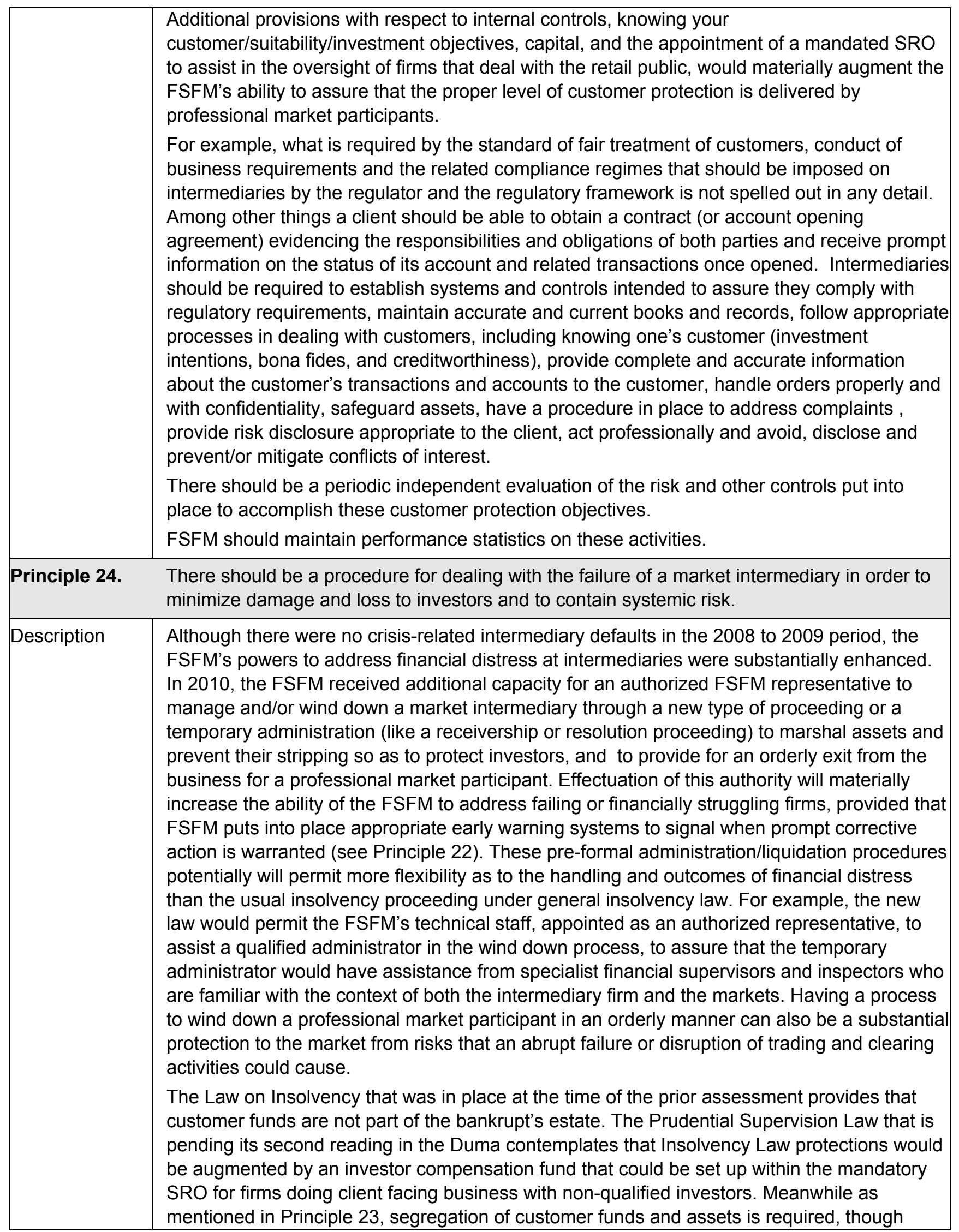




\begin{tabular}{|c|c|}
\hline & $\begin{array}{l}\text { there may be some issues, relative to the holding of nominee accounts, as to how this is } \\
\text { actually executed in practice. }\end{array}$ \\
\hline Assessment & Partly Implemented \\
\hline Comments & 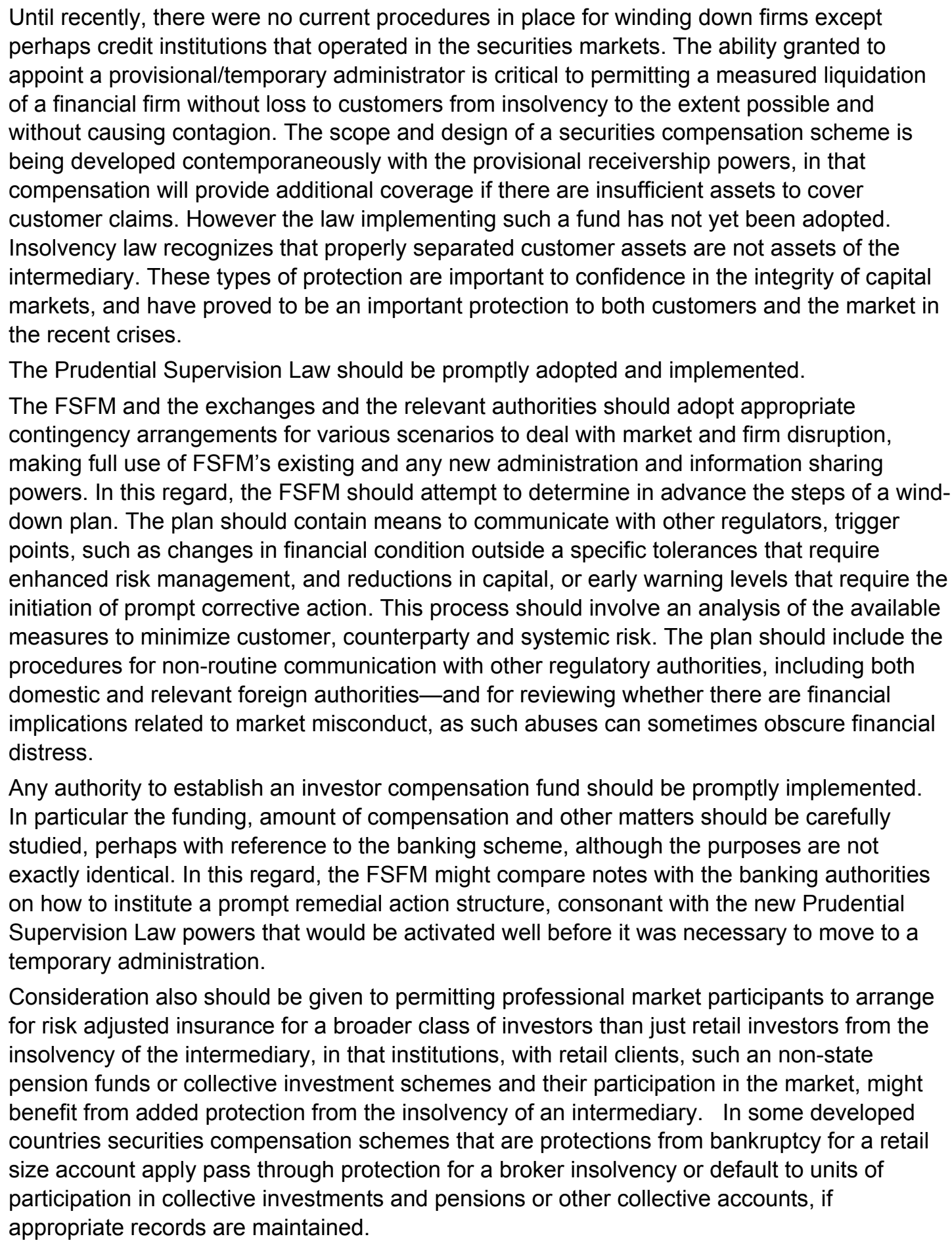 \\
\hline \multicolumn{2}{|r|}{ Principles for the Secondary Market } \\
\hline Principle 25. & The establishment of trading systems including securities exchanges should be subject to \\
\hline
\end{tabular}




\begin{tabular}{|c|c|c|c|c|c|c|c|c|c|c|}
\hline & \multicolumn{10}{|c|}{ regulatory authorization and oversight. } \\
\hline \multirow[t]{20}{*}{ Description } & \multicolumn{10}{|c|}{ Legal requirements } \\
\hline & \multirow{2}{*}{\multicolumn{10}{|c|}{$\begin{array}{l}\text { The Securities Law contains certain standards with respect to the authorization of exchanges } \\
\text { and organized markets, including derivatives markets. It is complemented by the recently } \\
\text { adopted Law on Clearing and FSFM regulation 10-78/pz-n adopted in 2010. Relevant } \\
\text { requirements will be further enhanced by pending legislation, "On Exchanges and Organized } \\
\text { Trading (Securities Exchange Law)" relating among other things to organized markets. The } \\
\text { laws thus cover trading systems and operators as well as full-fledged exchanges. } \\
\text { Market structure }\end{array}$}} \\
\hline & & & & & & & & & & \\
\hline & \multicolumn{10}{|c|}{$\begin{array}{l}\text { There are currently two exchange groups in Russia, the MICEX group and Russia Trading } \\
\text { System (RTS), which run fully electronic markets. Each of these groups operates more than } \\
\text { one trading system or market. Both are members of the World Federation of Exchanges that } \\
\text { maintains membership standards and conducts due diligence before admitting members. } \\
\text { Both exchanges report their futures and options statistics to the Futures Industry Association } \\
\text { that maintains volume statistics for listed derivatives markets. }\end{array}$} \\
\hline & \multirow{2}{*}{\multicolumn{10}{|c|}{$\begin{array}{l}\text { MICEX exchange statistics, which are located on a comprehensive website: www.micex.com, } \\
\text { demonstrate that more than } 80 \text { percent of volume is in the ten largest issues. The RTS } \\
\text { website: www.rts.ru/en/,also contains exchange activity statistics. Both exchange groups } \\
\text { provide information on rules and other matters on their sites in English as well as Russian. } \\
\text { FSFM statistics for } 2010 \text {, provided as part of this exercise, indicates that there were } 364 \\
\text { issuers of corporate bonds for } 663 \text { issues, with a value in circulation of US } \$ 88.6 \text { billion and a } \\
\text { value in circulation of US } \$ 81.1 \text { billion in government bonds. FSFM statistics give the number } \\
\text { of companies admitted to trade at all organized markets in } 2010 \text { as } 499 \text {. } \\
\text { The following tables give some detail on listed equities (not including mutual funds) and } \\
\text { futures contracts traded: }\end{array}$}} \\
\hline & & & & & & & & & & \\
\hline & \multicolumn{3}{|l|}{ MICEX } & & \multicolumn{2}{|c|}{ Jan-09 } & \multicolumn{2}{|r|}{ Jan-10 } & \multirow{2}{*}{\multicolumn{2}{|c|}{$\frac{a n-11}{250}$}} \\
\hline & \multicolumn{3}{|c|}{ Number of Listed Equities } & \multicolumn{3}{|c|}{235} & \multicolumn{2}{|r|}{235} & & \\
\hline & \multicolumn{3}{|c|}{ Market Capitalization, US\$ millions } & & \multicolumn{2}{|c|}{277,725} & \multicolumn{2}{|r|}{843,697} & \multirow{2}{*}{\multicolumn{2}{|c|}{$13,989.7$}} \\
\hline & \multicolumn{3}{|c|}{$\begin{array}{l}\text { Value of Bond Trading, } \\
\text { US } \$ \text { millions }\end{array}$} & & \multicolumn{2}{|r|}{2,061} & \multicolumn{2}{|r|}{16,946} & & \\
\hline & \multicolumn{3}{|c|}{ Share Turnover Velocity* } & \multicolumn{3}{|c|}{41.13 percent } & \multicolumn{2}{|c|}{42.15 percent } & \multicolumn{2}{|c|}{37.26 perce } \\
\hline & \multicolumn{10}{|c|}{$\begin{array}{l}\text { sources: World Federation of Exchanges } \\
\text { (http://www.world-exchanges.org/statistics/ytd-monthly) } \\
\text { Center for Capital Market Development Foundation, FFMS } \\
\text { *Share turnover velocity is defined as EOB domestic trading value as numerator and } \\
\text { domestic market cap as denominator }\end{array}$} \\
\hline & \multicolumn{2}{|l|}{ RTS } & \multicolumn{2}{|c|}{2005} & 2006 & 2007 & \multicolumn{2}{|r|}{2008} & 2009 & 2010 \\
\hline & \multicolumn{2}{|c|}{ Number of Listed Companies } & & 8 & 63 & & & 110 & 81 & 77 \\
\hline & Source: Cent & or Capital Mar & et $\mathrm{L}$ & $\mathrm{ve}$ & opmen & t Founc & lation, & FFMS & & \\
\hline & $\begin{array}{l}\text { Derivatives } \\
\text { Exchange }\end{array}$ & $\begin{array}{l}\text { Contracts } \\
\text { traded } 2007\end{array}$ & & & & $\begin{array}{l}\text { Contra } \\
\text { traded }\end{array}$ & $\begin{array}{l}\text { cts } \\
2009\end{array}$ & Contrac & trade & d 2010 \\
\hline & MICEX & $85,386,473$ & & & 843 & 19,25 & 9,675 & & & $, 978,357$ \\
\hline & RTS SE & $144,922,653$ & & & 668 & 474,44 & 0,043 & & 617 & 856,123 \\
\hline & Source: Futu & ndustry Asso & iatic & & & & & & & \\
\hline & Both MICEX an & TS operate se & & & & & & & & \\
\hline
\end{tabular}


exchange market (since 1992) that is supervised by the CBR and in fact used by the CBR to intervene with respect to ruble/US dollar rates; the federal government bond market (since 1993); derivative financial instruments (1996); the Stock Exchange (SE) for cash equities (1997); corporate and regional government fixed income (1999); the National Mercantile Exchange (NAMEX) (2008); a commodity market, which trades grains among other things; and a market in municipal government securities (2010). MICEX SE is the principal equity market for Russia, which operates on a fully prepaid basis; more than half of the daily volume is equity repos. As part of the exchange group, MICEX also operates a clearing organization and a depository, the National Clearing Depository.

RTS operates several markets in equities, RTS Standard, RTS Classic, which is an interdealer market with pre-established limits and RTS T+0 which is a repo market and which requires 100 percent prepayment. Very few repo trades are accomplished on RTS and RTS Standard is the most active equity market. RTS also operates: START, a mid-cap and small cap market; and a Futures and Options RTS or FORTS, which has a daily volume of US $\$ 6$ to 7 billion, and trades 38 futures and 15 options, the most popular of which are indexes. Like MICEX, RTS operates commodity markets, but in energy and some metals. Its clearing operation is known as RTS Clearing House (RTS CH). RTS CH has contingency funds of US $\$ 42$ million, a reserve of US $\$ 28$ million, equity of US $\$ 63$ million, and collateral of US $\$ 855$ million. According to RTS, the RTS $\mathrm{CH}$ model for a CCP is the model that was used in developing the legislation for the creation of a CCP with close out netting arrangements that were founded in law. RTS also has a depository, DCC. Reportedly almost 100 percent of OTC transactions that are required to be reported are reported to DCC.

\section{Planned consolidation}

In March 2011 it was announced that the two Russian exchanges had signed a letter of intent to explore the possible synergies that could be attained through merger. A final merger agreement was signed June 29, 2011 and although views differ as to whether the transaction will occur, details are expected to emerge and currently the transaction is expected to close before the end of calendar year 2011.

Both markets have several tiers of listing as well as securities that are not listed but are admitted to trading. Each offer quote driven as well as order driven markets-to address minimally traded securities among other things. All securities must have a prospectus, and provide continuous disclosures and financial reports (See Principle 14). Shares traded "off the list," that is that are admitted to trading without a listing, are not required to have the track record, such as three years performance, that would typically be required for a top tier listing, and hence this type of offering is subject to greater risks. A huge percentage of the volume on MICEX is driven by about 10 issues on the main list, with more than 25 percent in Gazprom. Similarly a huge percentage of the volume is done by a small number of brokers.

RTS has some retail prop traders. The free float in most securities traded is relatively low, often under 20 percent, and sometimes substantially less.

The tiering identifies the riskier offerings, which should operate as a customer protection, provided investors understand the differences between the tiers. Information on the exchange websites does provide information on the distinctions among the different types of offerings and listing requirements. In particular, as set forth above, RTS has an English language website containing substantial relevant information including the CCP requirements and the composition of the "clearing waterfall," or order in which financial resources intended to support the completion of trades following a default are to be accessed.

\section{Participation}

Participation directly by individuals in the equity markets in Russia is not high, but is gradually 


\begin{tabular}{|c|c|}
\hline & 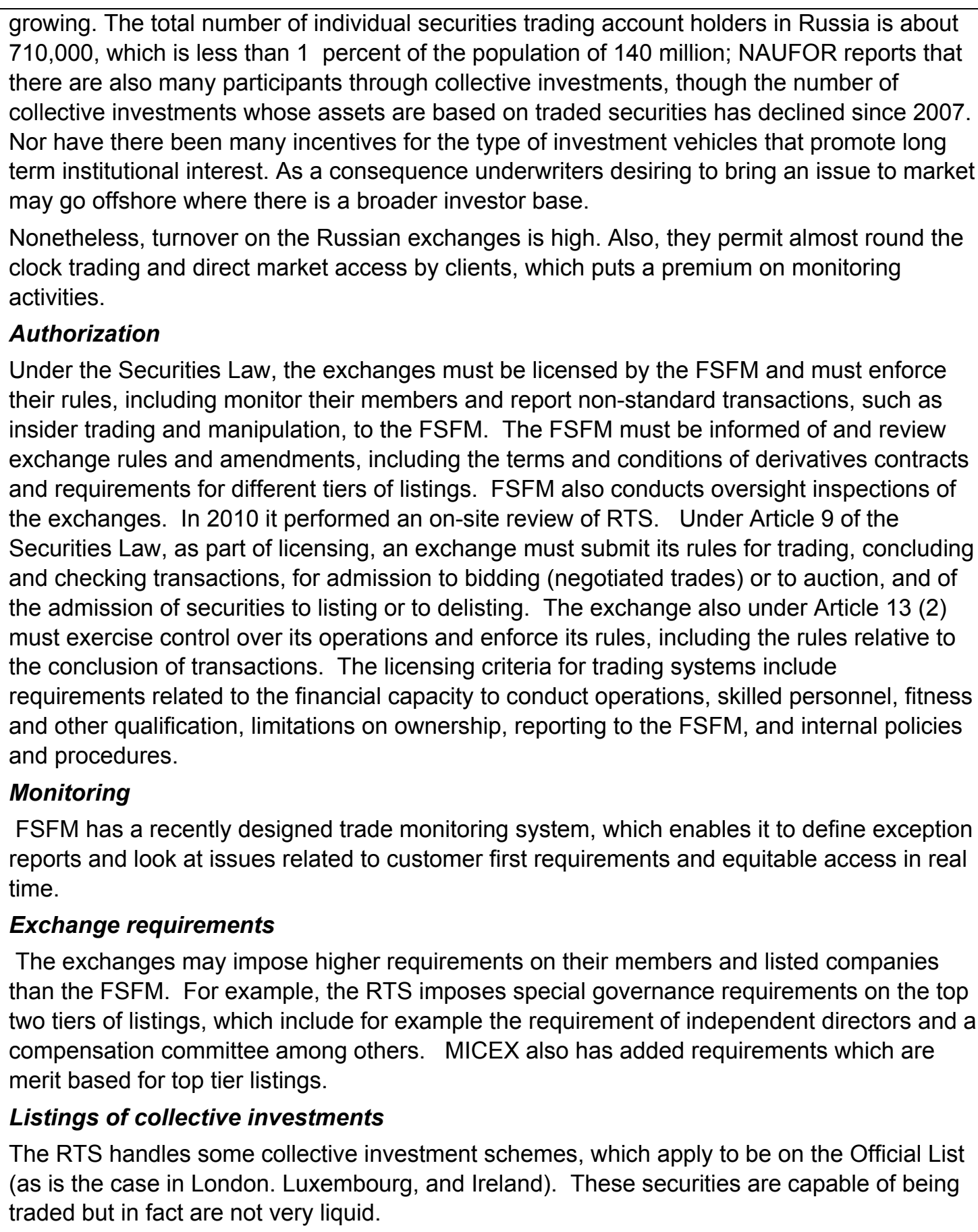 \\
\hline Asse & Broadly Implemented \\
\hline Co & $\begin{array}{l}\text { Due to multiple categories of products that are admitted to trading or listing with different } \\
\text { qualification standards and trading characteristics, it is recommended that steps be taken to } \\
\text { assure that these differences are highlighted to customers through disclosure. In this respect } \\
\text { the FSFM does state that the negotiated prices are disclosed separately from auction or firm } \\
\text { quotation prices. } \\
\text { New securities and exchange legislation is pending that will provide additional requirements } \\
\text { for all organized markets. The FSFM has significant tools in place to address trading }\end{array}$ \\
\hline
\end{tabular}




\begin{tabular}{|c|c|}
\hline & $\begin{array}{l}\text { oversight and has installed a new team to conduct such oversight. Some experience with } \\
\text { these systems is required to determine how well they work in practice (see discussion under } \\
\text { Principle 7) so the FSFM should establish and maintain performance metrics on their use. } \\
\text { Additionally, the FSFM should undertake either to assure that the exchanges, or any SRO } \\
\text { mandated for professional market participants dealing with the retail market, provide } \\
\text { information to customers that clarifies the differences among offerings in different listing tiers } \\
\text { and addresses account opening requirements that permit the client to specify risks that they } \\
\text { are willing to take. } \\
\text { Russian markets currently have prophylactic provisions such as individual price limits to } \\
\text { prevent or mitigate market disruptions. In that market structure is increasingly an issue } \\
\text { among regulatory authorities (and could have systemic consequences if leverage is permitted } \\
\text { and proper arrangements are not in place to address price spikes), the exchanges should } \\
\text { (whether merged or separate) keep abreast of developments on issues related to the integrity } \\
\text { of electronic markets, direct market access, addressing gridlock, price cascades, etc., and } \\
\text { take steps to make adaptations as necessary to existing normative rules and guidance. }\end{array}$ \\
\hline Principle 26. & $\begin{array}{l}\text { There should be ongoing regulatory supervision of exchanges and trading systems, which } \\
\text { should aim to ensure that the integrity of trading is maintained through fair and equitable rules } \\
\text { that strike an appropriate balance between the demands of different market participants. }\end{array}$ \\
\hline Description & 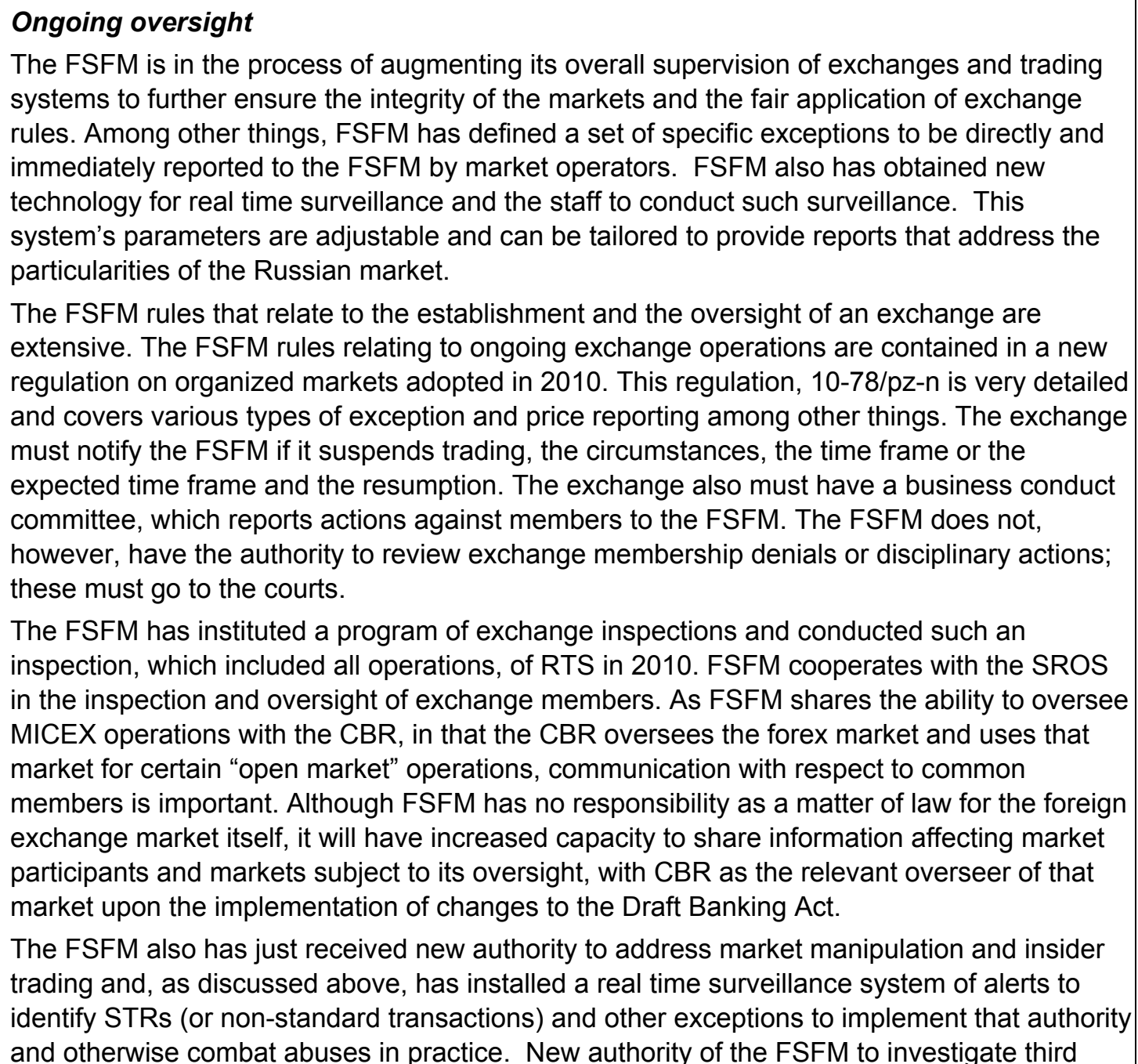 \\
\hline
\end{tabular}




\begin{tabular}{|c|c|}
\hline & $\begin{array}{l}\text { party transactions in connection with insider trading and market manipulation augments pre- } \\
\text { existing more general authority and should permit FSFM and the markets to act more } \\
\text { aggressively to oversee rules against market abuse and misconduct. The authority will } \\
\text { require the development of internal programs at both the exchanges and the FSFM to apply } \\
\text { the new authority and some experience with the development of the appropriate parameters } \\
\text { for defining non-standard transactions and other exception reports relevant to market } \\
\text { oversight. (see Principle } 28 \text {. The FSFM is working actively in these areas. } \\
\text { The general powers of the FSFM appear to include the power to suspend a license, including } \\
\text { a license for an authorized organized market. }\end{array}$ \\
\hline Assessment & Broadly Implemented \\
\hline Comments & $\begin{array}{l}\text { See also the comments under Principle } 25,27,28 \text { and } 29 \text {. FSFM should have a clear } \\
\text { medley of interventions that it can make in order to oversee, and enforce its rules relative to } \\
\text { the oversight of the activities of licensed markets. }\end{array}$ \\
\hline Principle 27. & Regulation should promote transparency of trading. \\
\hline Description & 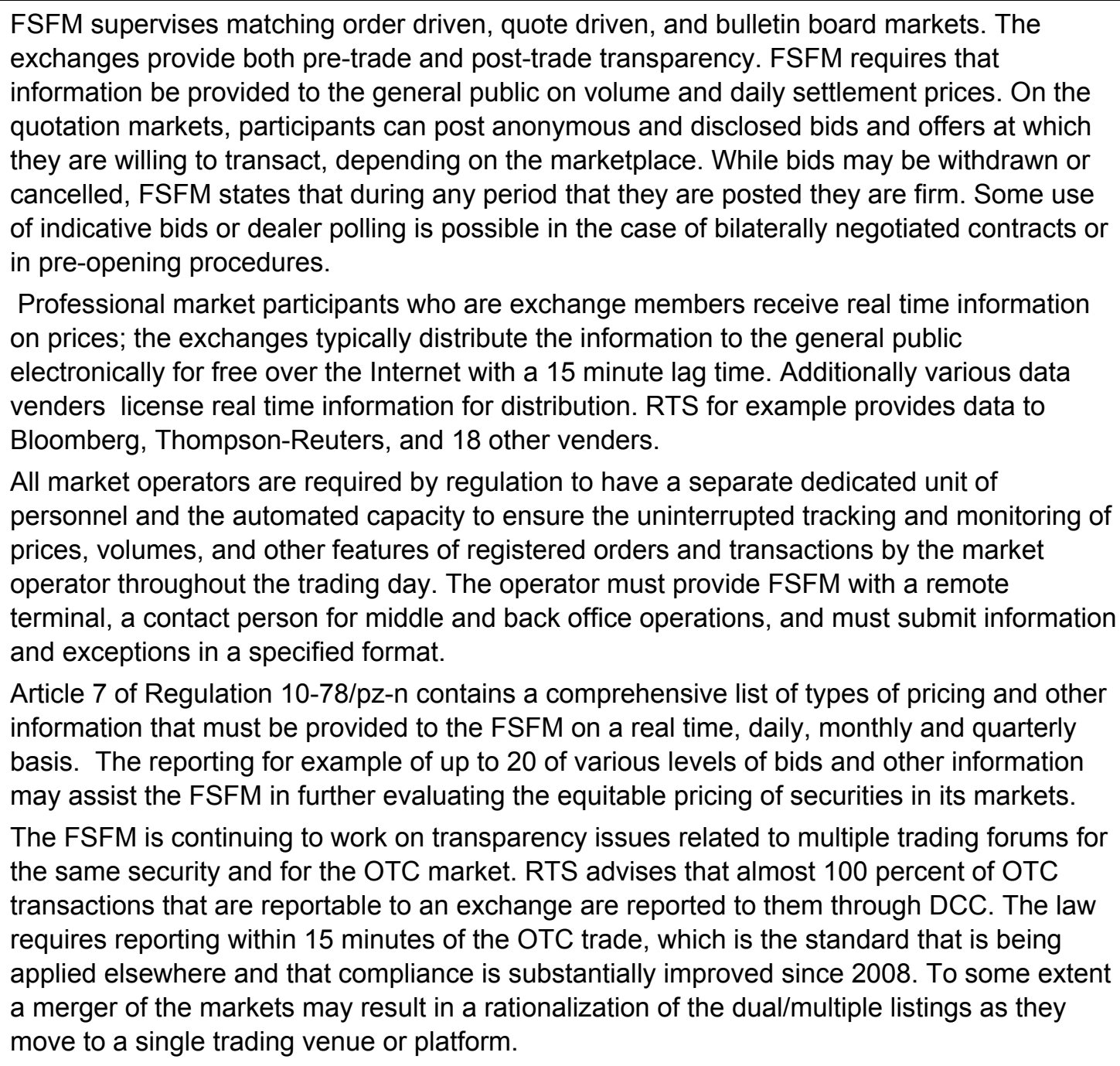 \\
\hline Assessment & Partly Implemented \\
\hline Comments & The question remains from earlier assessments as to whether multiple listings of the same \\
\hline
\end{tabular}




\begin{tabular}{|c|c|}
\hline & 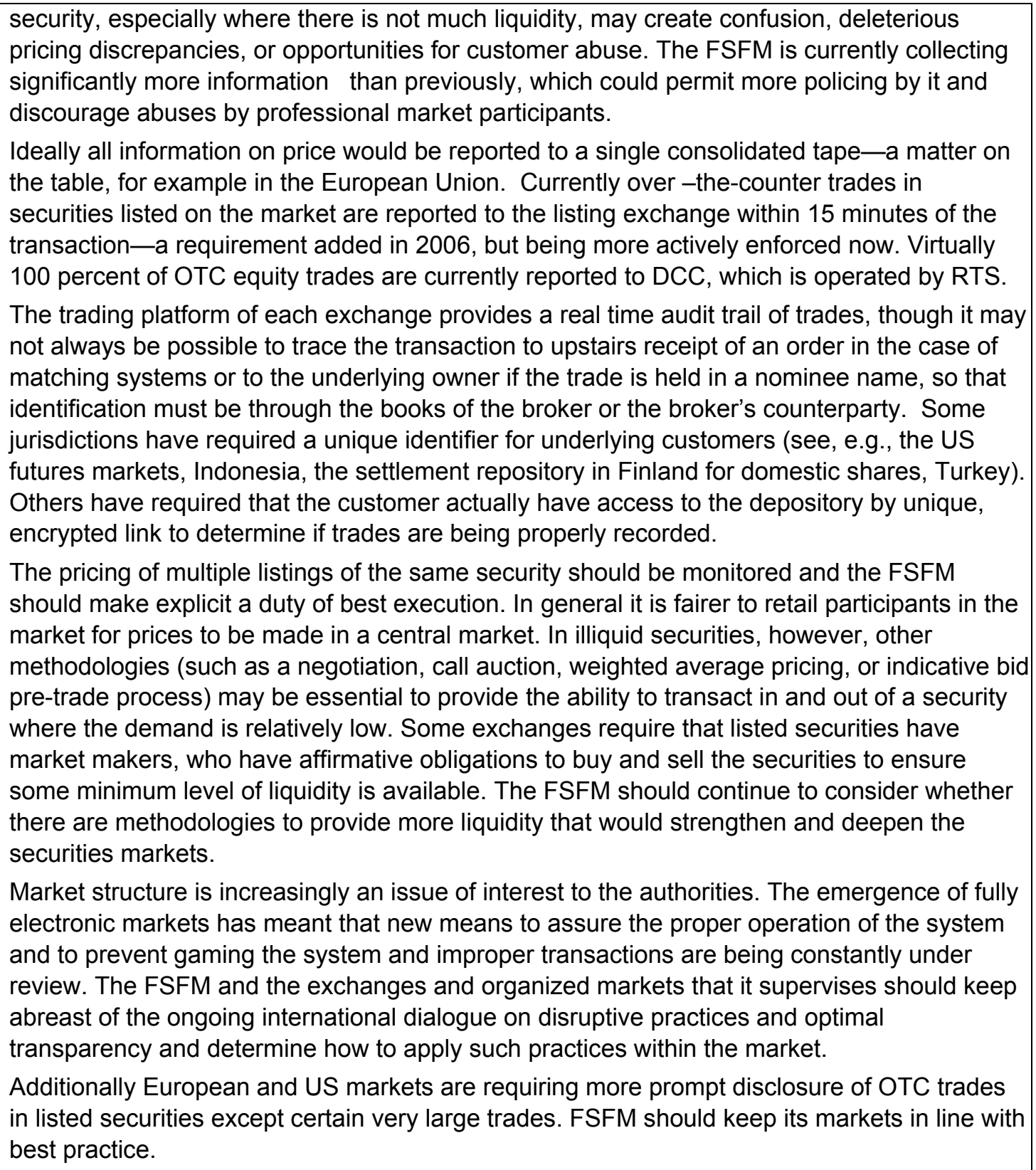 \\
\hline Principle 28. & $\begin{array}{l}\text { Regulation should be designed to detect and deter manipulation and other unfair trading } \\
\text { practices. }\end{array}$ \\
\hline Description & $\begin{array}{l}\text { After a Herculean multi-year effort the FSFM has succeeded in obtaining new legislation, the } \\
\text { Insider Law, FZ224, on market abuse, in particular, manipulation and insider trading, that was } \\
\text { adopted in } 2010 \text { and became effective except for certain criminal provisions at the end of } \\
\text { January } 2011 \text {. The law is intended to ensure the fair pricing of financial instruments, foreign } \\
\text { currencies or commodities and the equitable treatment of investors (Article } 1 \text { (1)) on } \\
\text { organized markets. The FSFM also has installed a real time system for reporting non- } \\
\text { standard transactions: ITNICE/Actimize, for which designated FSFM personnel can set } \\
\text { parameters to detect unfair trading practices, such as front-running, in general. Each market } \\
\text { operator also must be able to (i) monitor trading in real time, (ii) reconstruct trading activity, } \\
\text { and (iii) report various types of specified non-standard transactions pursuant to regulation 10- }\end{array}$ \\
\hline
\end{tabular}




\begin{tabular}{|c|c|}
\hline & 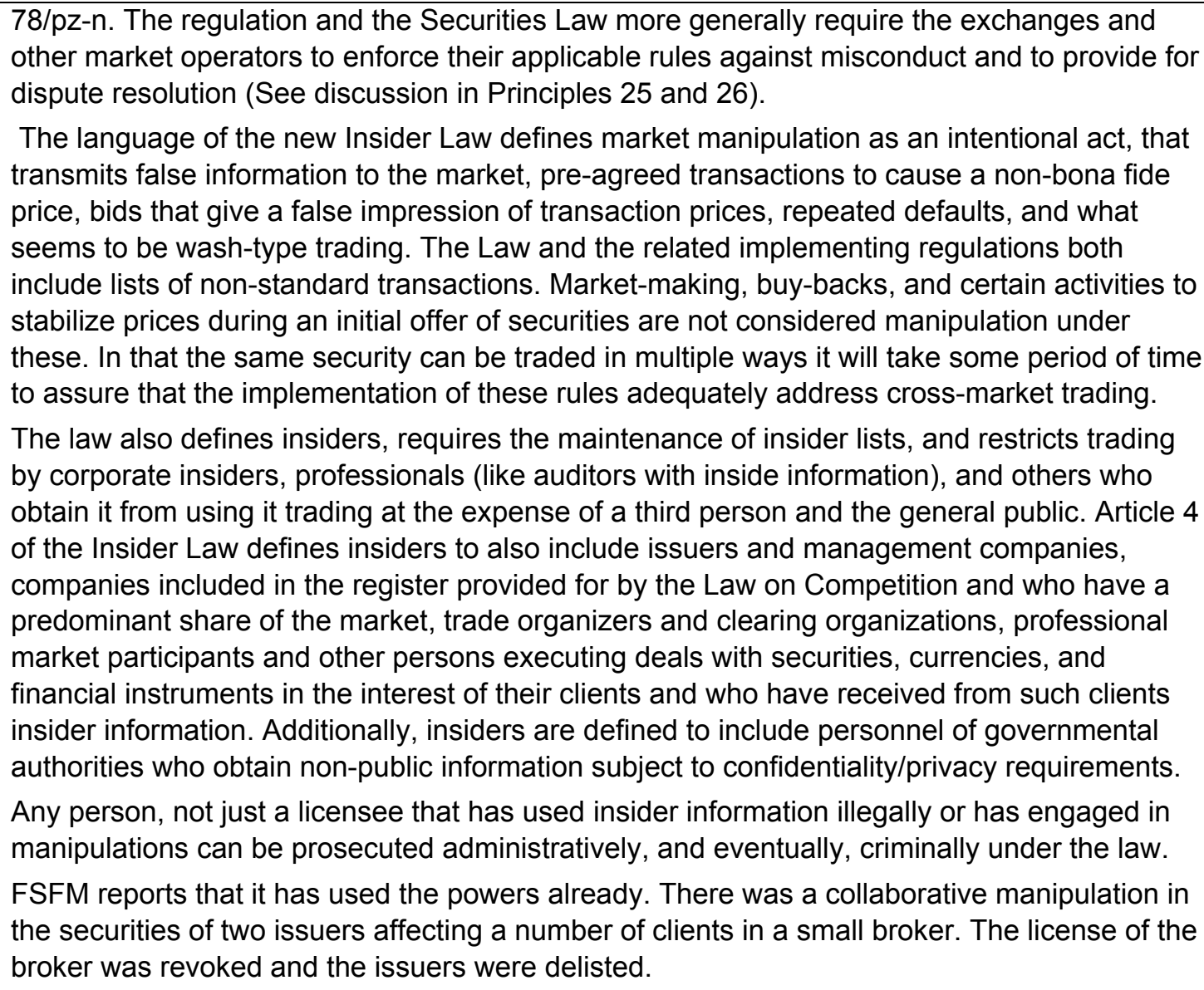 \\
\hline Assessment & Partly Implemented \\
\hline Comments & $\begin{array}{l}\text { The mechanisms are now in place to bring administrative actions against insider dealing and } \\
\text { manipulation, including the requirement (which has been adopted under the law) that market } \\
\text { operators must have adequate monitoring systems to address these abuses. Nonetheless, } \\
\text { the law is brand new and there has been almost no experience with its application. } \\
\text { The elements intended to define market abuses with more particularity are set forth, including } \\
\text { a list of specific types of transactions as well as a general prohibition. Although these } \\
\text { provisions have not been fully tested in practice, it is encouraging that a case already has } \\
\text { been undertaken and that there are monitoring systems and other resources already in place } \\
\text { to apply the law. It is also an extremely important accomplishment to have achieved this } \\
\text { change in the law. } \\
\text { The prescribed penalties, while materially increased over past penalties, remain small } \\
\text { pending the phasing in of criminal penalties, which include imprisonment. But, in addition to } \\
\text { specified monetary penalties, the Insider Law also permits FSFM to impose the remedy of } \\
\text { disgorgement of illegal profits; if effectively deployed, this remedy should be a substantial } \\
\text { disincentive to such market misconduct. Further FSFM retains the capacity to suspend } \\
\text { operations of any person for six months under the Investor Protection Law for violations of } \\
\text { the law. } \\
\text { In general, many jurisdictions are in the process of tightening the definitions of manipulation } \\
\text { and disruptive practices, and insider abuses are everywhere difficult to prosecute without } \\
\text { strong evidence. Some experience will be necessary, therefore, to determine whether the } \\
\text { existing penalties are sufficiently dissuasive. See for example the discussion under Principle }\end{array}$ \\
\hline
\end{tabular}




\begin{tabular}{|c|c|}
\hline & $\begin{array}{l}\text { 10. With such experience, the FSFM should achieve a higher level of compliance on this } \\
\text { Principle. }\end{array}$ \\
\hline Principle 29. & $\begin{array}{l}\text { Regulation should aim to ensure the proper management of large exposures, default risk and } \\
\text { market disruption. }\end{array}$ \\
\hline \multirow[t]{8}{*}{ Description } & $\begin{array}{l}\text { Short selling on the exchanges is suspended as a matter of law if an individual share price } \\
\text { drops } 3 \text { percent from the last trade price for a prescribed limited period. There also are other } \\
\text { individual price limits if the price drops } 15 \text { percent. How the latter limits are accommodated } \\
\text { within indexes should be explored. }\end{array}$ \\
\hline & $\begin{array}{l}\text { Margin trading on the RTS in equities is settled currently through a central counterparty, and } \\
\text { margins are set at from } 30 \text { to } 50 \text { percent on the RTS for cash securities. Futures margin is } \\
\text { able to be posted on-line, is assigned on a contract-by-contract scale and applied on a } \\
\text { portfolio basis, which in some cases may result in offsets which produce very low net } \\
\text { amounts. The resources of any defaulting customer, carrying firm, and the clearing } \\
\text { organization may be used in accordance with the rules to address a default situation, which } \\
\text { specifies the order in which such resources may be drawn upon. All of these default } \\
\text { procedures are transparent and recorded on the RTS website. }\end{array}$ \\
\hline & $\begin{array}{l}\text { Currently at the MICEX and RTS, many cash securities transactions are pre-paid for in full } \\
\text { and securities are deposited before a trade is concluded. This process is intended to virtually } \\
\text { eliminate settlement risk. }\end{array}$ \\
\hline & $\begin{array}{l}\text { The enactment of the legal framework supporting CCP Clearing potentially will permit more } \\
\text { trading to be conducted on margin where the margin will be transparent to the market. The } \\
\text { new law establishes a clear legal basis for clearing, finality and close out netting. The law } \\
\text { related to CCP clearing also calls for establishment of a risk management program, which } \\
\text { takes into account the open exposures in the marketplace and sets certain specific limits } \\
\text { regarding leverage. The implementation of that law will require the submission for FSFM } \\
\text { approval and publication of rules by the exchanges and the clearing arrangements affecting } \\
\text { the clearing contract, clearing operations, liabilities and responsibilities of all relevant parties, } \\
\text { and other matters. In that respect, the FSFM will have the opportunity to further assure that } \\
\text { the types of information and risk measures that should be available on open positions and } \\
\text { concentrations as stated in the Key Issues and Questions listed in Principle } 29 \text {, taking into } \\
\text { consideration the limited number of fails and the amount of margined trades, are in place or } \\
\text { enhanced. Some monitoring of margins will also be necessary to back test their } \\
\text { effectiveness, especially whether the permitted offsets are not resulting in under-margining of } \\
\text { relevant risks. }\end{array}$ \\
\hline & $\begin{array}{l}\text { Repeatedly failing to deliver on transactions would potentially constitute a manipulation or } \\
\text { market abuse under the new Insider Law. }\end{array}$ \\
\hline & $\begin{array}{l}\text { (See also below the discussion of how the ability to use a temporary administration subject to } \\
\text { adoption of pending legislation could improve FSFM's ability to address firm and market } \\
\text { disruptions.) }\end{array}$ \\
\hline & Authorized representative and management of market issues \\
\hline & $\begin{array}{l}\text { The Prudential Supervision Law will permit the appointment of an authorized representative } \\
\text { to a professional market participant whose license is suspended or revoked or in the event of } \\
\text { institution of a temporary administration for other circumstances, which could include financial } \\
\text { uncertainty, undue market exposures, or market abuses. In either case, such authorized } \\
\text { representative must be an FSFM employee. Authorized representatives will have broad } \\
\text { authority to oversee operations of the participant, including the ability to approve transactions } \\
\text { that exceed one percent of assets or limit the activities of executives of the firm that remain in } \\
\text { place (like a debtor in possession in a reorganization type structure). These measures are }\end{array}$ \\
\hline
\end{tabular}




\begin{tabular}{|c|c|}
\hline & $\begin{array}{l}\text { proposed to be added to permit the marshalling and preservation of company assets, and the } \\
\text { protection of customers and other creditors. Further work will need to be done to determine } \\
\text { with more specificity, how such authority would be used; and whether once initiated how best } \\
\text { wind downs can be accomplished practicably without loss to customers of a major market } \\
\text { participant, or of a major market participant due to the failure of a customers, in the case of } \\
\text { futures-style trading. } \\
\text { Contingency planning } \\
\text { As stated under Principles } 24 \text { and 1, planning how best to address major risk factors through } \\
\text { protocols with the other financial regulatory/supervisory authorities is essential to designing } \\
\text { effective prudential regimes in jurisdictions with multiple authorities. Such planning is } \\
\text { important to identifying risk and possible risk transmission factors, and in contingency } \\
\text { planning. While FSFM cooperates informally, contingency measures have not yet been } \\
\text { spelled out more formally consistently with the need to avoid unnecessary disruption while } \\
\text { preserving flexibility to act taking into consideration specific circumstances prevailing in the } \\
\text { Russian markets. The FSFM currently has the authority to share information on large } \\
\text { exposures with other domestic regulators/supervisors and also potentially with relevant } \\
\text { foreign authorities. It should be confirmed that the CBR can also provide mutual assistance to } \\
\text { the FSFM to the extent a market disruption or firm failure involves exposures in the markets, } \\
\text { or groups supervised by the other authority. The pending Banking Amendments should } \\
\text { support that process. }\end{array}$ \\
\hline Assessment & Partly Implemented \\
\hline Comments & $\begin{array}{l}\text { As stated in Principles } 1 \text { and } 24 \text {, the FSFM should refine and document its existing } \\
\text { arrangements for cooperation with the CBR and the exchanges with a view to further } \\
\text { articulating the actions that can be taken to address the default or failure of a professional } \\
\text { market participant or a market disruption through temporary administration, instructions to } \\
\text { market operators, suspension of trading or exercise of any other oversight authority. In this } \\
\text { connection FSFM should consider the following: } \\
\text { - Reviewing concentrated exposures and developing a menu of approaches to addressing } \\
\text { problems before the fact is a good discipline for regulators as it keeps them in touch with the } \\
\text { types and levels of risks experienced in the markets. } \\
\text { - The nuclear option of shutting down an exchange or clearing organization is likely not to } \\
\text { be desirable, so it is important to determine in advance what practical prompt steps may be } \\
\text { needed to reduce the possibility that problems at failing firms, or abrupt adjustment of prices } \\
\text { in the market, will spread contagion. } \\
\text { - The establishment and periodic adjustment of pre-known trigger points (such as early } \\
\text { warning capital and concentration levels, price limits, short-selling limits, circuit breakers-of } \\
\text { specified duration-what if analysis based on price moves, or other measures) permit a } \\
\text { stepped up or stepped down approach to market disruptions and firm failures, tailored } \\
\text { interventions, and can avoid the introduction of risk that attaches to ad hoc actions.. } \\
\text { The development of normative processes under the authority of the new Prudential } \\
\text { Supervision Law, if adopted, and under the Clearing Law that recently became effective, will } \\
\text { require the FSFM to work with the operators of markets and clearing arrangements in } \\
\text { considering the best means of monitoring the performance of the operative clearing, and } \\
\text { related margining, systems over time to measure that these properly mitigate rather than } \\
\text { increase risks. FSFM should consider what information it needs about gross exposures in } \\
\text { testing the sufficiency of risk management procedures, and should keep abreast of ongoing } \\
\text { guidance on the level of coverage of potential defaults and the availability of liquidity } \\
\text { arrangements required by international standards. }\end{array}$ \\
\hline
\end{tabular}




\begin{tabular}{|c|c|}
\hline & $\begin{array}{l}\text { The equity repo markets also should be carefully monitored to assure that risks are } \\
\text { appropriately and timely addressed in that } 90 \text { percent of the market is in overnight repos and } \\
\text { the cash is likely used to finance dealing activities. }\end{array}$ \\
\hline Principle 30. & $\begin{array}{l}\text { Systems for clearing and settlement of securities transactions should be subject to regulatory } \\
\text { oversight, and designed to ensure that they are fair, effective and efficient and that they } \\
\text { reduce systemic risk. }\end{array}$ \\
\hline Description & 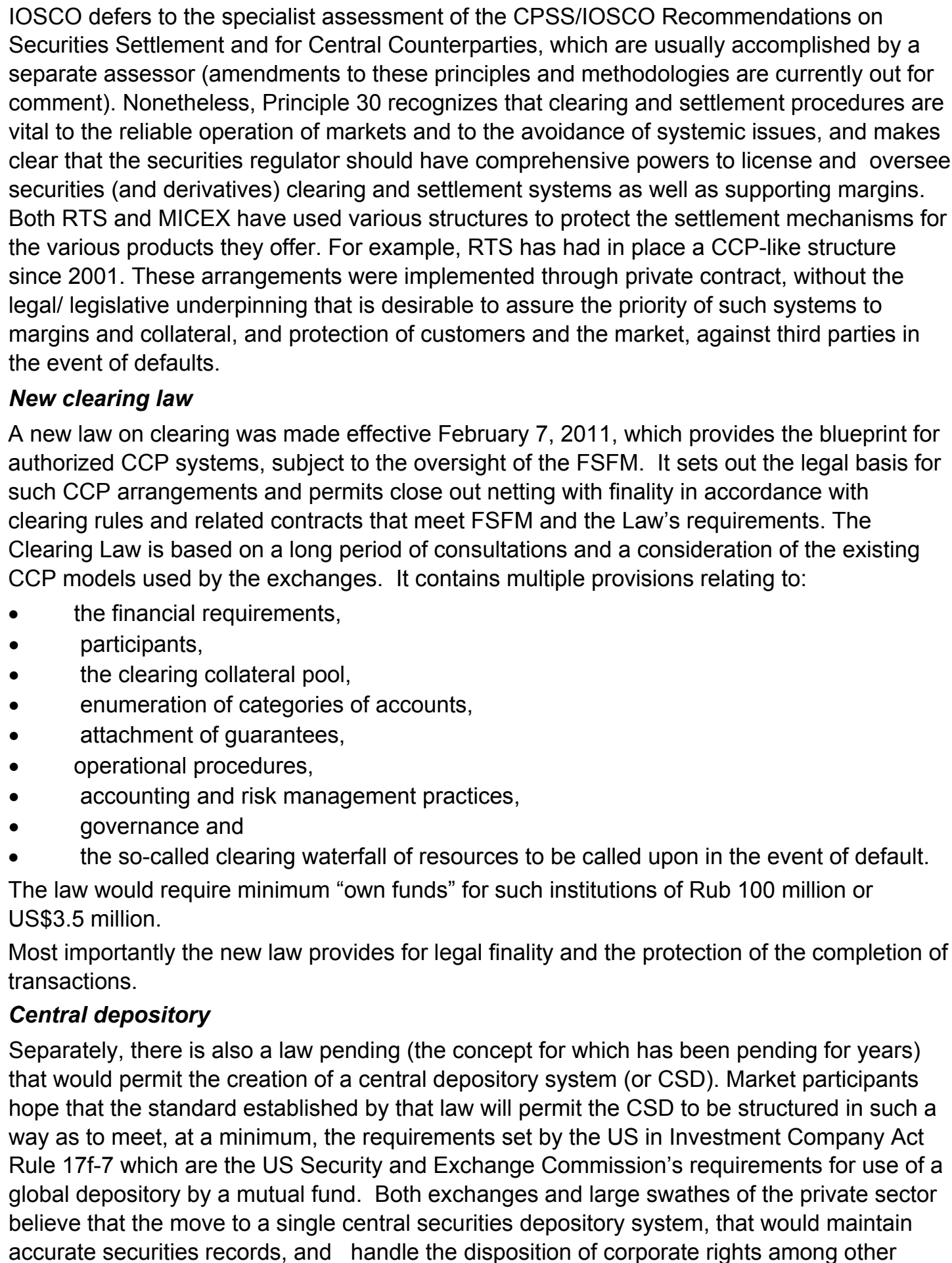 \\
\hline
\end{tabular}




\begin{tabular}{|c|c|}
\hline & $\begin{array}{l}\text { things, would provide additional comfort to users of the market as to the integrity of the } \\
\text { property interests that are exchanged, reduce transaction costs, and further clarify the liability } \\
\text { for the integrity of share registers. Such a change would also assure an independent registry } \\
\text { of dematerialized securities, which may not be offered under the current system, where } 48 \\
\text { registrars (down from 100s) operate. As a developmental matter, a change that moves } \\
\text { toward such a facility is believed essential to securing broader participation in Russian } \\
\text { markets by longer term investors and investors from foreign markets that are not just taking } \\
\text { speculative risk. Such a system could be a combination system that does not eliminate } \\
\text { transfer agents altogether, as is the case for certain systems that operate in Europe and } \\
\text { elsewhere. } \\
\text { A primary recommendation of the CPSS/IOSCO Principles, for settlement systems is that the } \\
\text { legal context to support the system must be enshrined in the law. This is because it is not } \\
\text { clear that settlement finality can be conferred with certainty by contract and because priorities } \\
\text { in collateral and how property is encumbered may be subject to mandatory laws which } \\
\text { cannot be altered by a clearing contract without enabling legislation. Therefore the adoption } \\
\text { of the Clearing Law is a very significant accomplishment. } \\
\text { The settlement time frames of T+4 or negotiated settlement that prevail in some } \\
\text { circumstances in the markets are curiosities that may be considered to be inconsistent with } \\
\text { international best practice as well as standards. Measures should be in place to assure that } \\
\text { these do not introduce systemic risks. }\end{array}$ \\
\hline Assessment & Not assessed \\
\hline Comments & 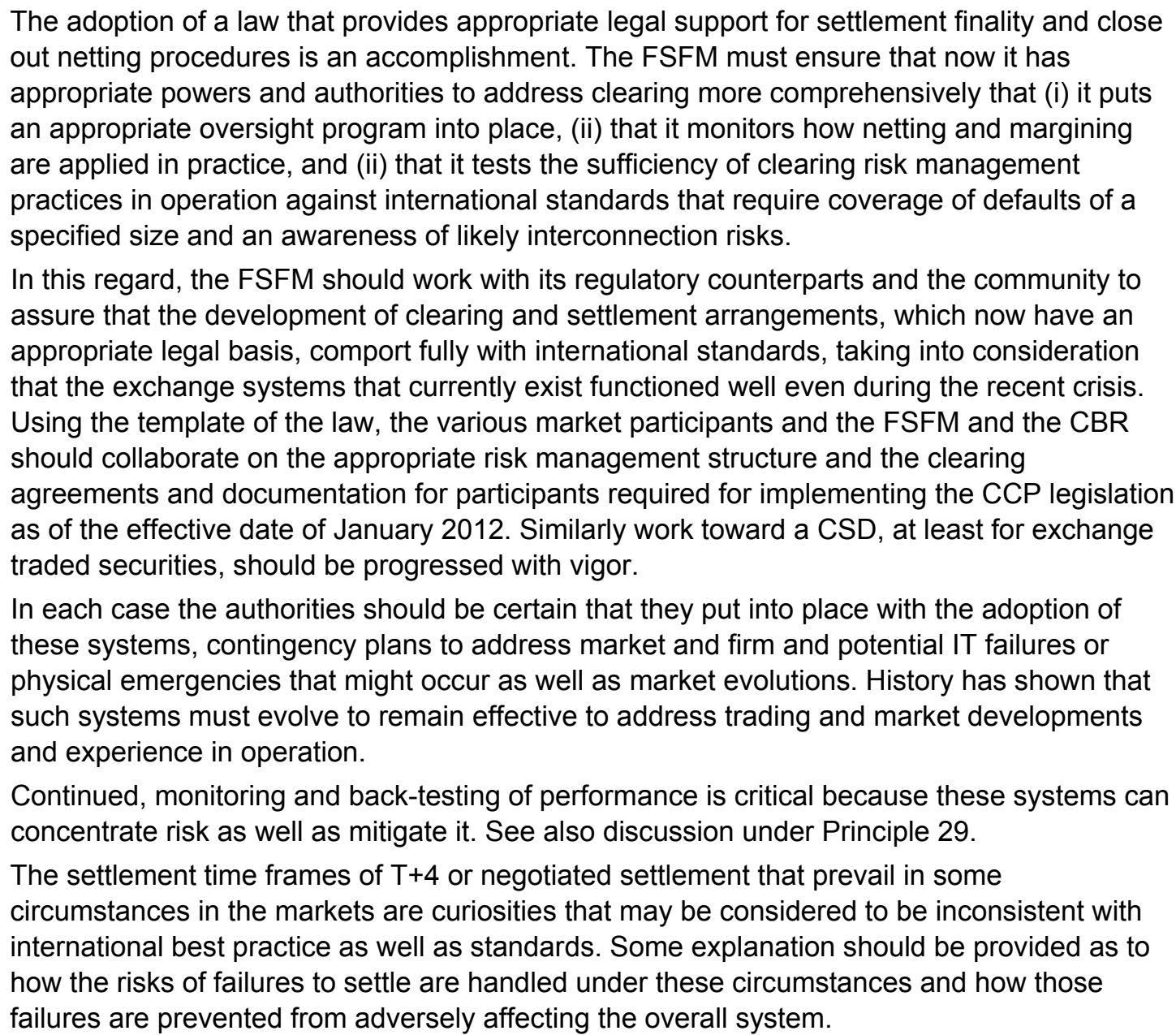 \\
\hline
\end{tabular}

